\title{
Tabagismo sob a ótica da Promoção da Saúde: Reflexão do professor sobre sua prática
}

\section{Maisa Rose Domenico Elmôr}

Tese de Doutorado apresentada ao Departamento de Prática de Saúde Pública da Faculdade de Saúde Pública da Universidade de São Paulo.

Área de concentração: Serviços de Saúde Pública

Orientadora: $\operatorname{Prof}^{\mathrm{a}} \operatorname{Dr}^{\mathrm{a}}$ Isabel Maria Teixeira Bicudo Pereira 
Ao Criador que, ao longo de toda a minha existência, oferece mais e mais sua mão para guiar os meus passos.

À memória da minha adorada mãe Therezinha Marchioni Domênico que, com sua dignidade e amor, marcou definitivamente minha vida.

Ao Elmôr, esposo sensível e presente, que a cada dia fortalece a meiguice e a serenidade da nossa união.

Aos meus filhos, Franco e Lucas, pelo respeito e amor. 


\section{Agradecimentos}

A elaboração deste trabalho só foi possível porque pude contar com pessoas especiais que com carinho dedicaram momentos de seus dias para compartilhar da minha inquietação. A elas meus singelos agradecimentos:

À minha orientadora Profa. Dra Isabel Maria Teixeira Bicudo Pereira, pelo apoio e doçura dos nossos encontros.

À amiga paciente Cynthia Bydlowski pela valiosa ajuda durante o trabalho metodológico.

Ao Prof. Dr. Fernando Lefèvre e à Profa Dra. Ana Maria Simioni Lefèvre que com simpatia se mostraram sempre dispostos a auxiliar.

Ao Lucas Domênico Elmôr , amado filho, que com seriedade e competência mostrou-se sempre disposto a auxiliar, sugerir e incentivar.

Ao querido Sergio Domênico que com sua dedicação paternal e sua leitura testou a compreensão das palavras escritas nesta tese.

A Sra Maria Lúcia Evangelista de Ferraz e a todos os funcionários da biblioteca da FSP/USP que me auxiliaram durante as consultas bibliográficas.

A Cláudia Perrotta pelas sugestões e competente revisão que enriqueceram o trabalho.

A amiga Patrícia Fernanda de Almeida Fernandes pelo auxílio na revisão do segundo idioma.

A todos os professores e gestores das escolas participantes, por não conseguir enumerar aqui, quero deixar registrado meu carinho e desejo de um caminhar mais seguro. 


\section{Resumo}

Elmôr MRD. Tabagismo sob a ótica da promoção da saúde: reflexão do professor sobre sua prática [tese de doutorado]. São Paulo: Faculdade de Saúde Pública da USP; 2008.

Introdução: Os prejuízos causados, aos fumantes e não fumantes, pelo efeito dos componentes presentes no tabaco aparecem unânimes nos discursos de pesquisadores de todo o mundo. A Organização Mundial da Saúde (OMS) afirma que o tabagismo é a maior causa isolada evitável de doença e de morte. No cenário mundial, os Objetivos para o Desenvolvimento do Milênio propõem aos países a inclusão do controle do tabagismo como importante aspecto de desenvolvimento social. No Brasil o tabagismo é apontado como sendo o $2^{\circ}$ fator mais importante de risco de óbito com 200 mil mortes anuais. Estudos científicos confirmam que $90 \%$ dos fumantes adquirem o vício na adolescência. Por ser a escola local de permanência constante do jovem nesta faixa etária, para ampliar o olhar sobre uma ação educativa pode estar o professor propiciando reflexões sobre o hábito de fumar em seu ambiente de trabalho. Objetivo: O presente trabalho pretende construir os Discursos do Sujeito Coletivo que expressam as representações sociais de professores, frente à implantação de programas de controle do tabagismo nas escolas. A partir destes discursos, busca propor ações que poderão servir de apoio à proposta educativa de controle do tabagismo desenvolvida no ambiente escolar. Metodologia: A metodologia empregada, com base qualiquantitativa, esteve apoiada na técnica de análise dos depoimentos e montagem dos Discursos do Sujeito Coletivo, proposta inicialmente por Lefèvre e colaboradores (2000). Resultados: Os depoimentos de 39 professores pertencentes a duas escolas públicas estaduais do município de São Paulo permitiram a compreensão das representações sociais desse público alvo pesquisado. As idéias centrais obtidas a partir da aplicação do questionário revelaram que, entre as funções delegadas aos professores pela sociedade e poder público, $90 \%$ dos profissionais desta pesquisa expressaram aceitação em trabalhar com o tema nas escolas. Para os professores, os projetos sobre tabagismo na escola requerem atitudes inovadoras, além de estarem apoiados em materiais e profissionais especializados. Conclusão: Para que este profissional encontre espaço para adotar esta prática é necessária a sensibilização do poder público oferecendo melhores condições de trabalho e remuneração aos docentes, de tal forma que permita sua participação em grupos de reflexão e implementação do controle do tabagismo no ambiente escolar. $\mathrm{O}$ fortalecimento da Educação, permitindo que o público freqüente nas escolas se conscientize dos prejuízos causados pelo cigarro, promoverá e implementará medidas destacadas no Artigo 12 da Convenção Quadro para o Controle do Tabagismo isto é, "promover amplo acesso a programas eficazes e integrais de educação e conscientização do público sobre os riscos que acarretam à saúde, o consumo e a exposição do tabaco, incluídas suas propriedades aditivas".

Palavras-chave: Tabagismo, Programas de Tabagismo na escola, Promoção de Saúde, Promoção de Saúde Escolar Educação em Saúde, Escola, Professor. 


\section{Summary}

Elmôr MRD. Tabagismo sob a ótica da promoção da saúde: reflexão do professor sobre sua prática/Tobacco \& health promotion: teachers' reflection about their practice [Thesis]. São Paulo(BR): College of Public Health, USP; 2008.

Introduction: The damage caused to both smoker and non-smoker by the effects of tobacco's compounds seems to be unanimous on the researchers' speeches all over the globe. The World Health Organization (WHO) claims tobacco is the most intense evitable cause of disease and death, therefore the health promotion can contribute as a new paradigm about health-disease issues in society. In World scenario, the Millennium Development Goals propose to the countries the inclusion of tobacco control as an important social development aspect. In Brazil tobacco is the second most important factor the risk of death totalizing 200 thousand deaths per year, just standing behind the hypertension. Scientific studies confirm that $90 \%$ of the smokers get addicted in adolescence. Due to the fact of school to be the most constant place where people this age spend time, professors have to promote reflections about the habit of smoking inside their work environment. The concerning on recognizing this professional's speeches as a way of reaching the tobacco theme in school offers an initial step for dealing with prevent programs implementation and getting school aware about the actions of the Framework Convention for Tobacco Control. Objectives: The present proposal works with the Collective Subject Speeches which express the professor's social representations, related to the tobacco control programs implementation in schools. Using these speeches as a beginning, this work proposes ideas to serve as a support on educative actions developed inside the school. Methodology: The quantitative and qualitative methodology was supported by statement analytical techniques and the use of Collective Subject Speeches, first established by Lefèvre et al. (2000).Results: The 39 São Paulo public high school professors' statement allowed the common sense comprehension. The main ideas, obtained throughout the applications of the questionnaire revealed that among the professor's functions, which are settled by society and public power, $90 \%$ of the professionals who have participated of this research accept to work with this theme inside the schools. Concerning professors, working with tobacco projects in schools requires innovative attitudes besides being supported by appropriated materials and professionals. Conclusion: In order to find a good way for adopting these techniques the professional has to be sensitive to the public power and offer them better conditions of work and salary, in a way to have free time to participate of support groups and implement the tobacco control inside the schools. The enhancement of educational, communicational and the inside school public awareness will promote and implement issues contained on the $12^{\mathrm{a}}$ Framework Convention for Tobacco Control Article, as it says, "Promoting wide access to efficient programs and educational centers and public awareness about the problems related to the consumption and exposition to tobacco, including addictives properties"

Keywords: Smoking, Tobacco Programs, Health Promotion, Health Promotion School, School, Health education. 


\section{Lista de Figuras}

FIGURA 1: Distribuição da proporção (\%) dos professores entrevistados segundo sexo. São Paulo, 2006.

FIGURA 2: Distribuição da proporção $(\%)$ de professores quanto ao hábito de fumar. São Paulo, 2006.

FIGURA 3: Distribuição da proporção (\%) dos entrevistados segundo idade.

São Paulo, 2006.

FIGURA 4: Distribuição da proporção (\%) de professores segundo exercício do cargo. São Paulo, 2006.

FIGURA 5: Distribuição da proporção (\%) dos entrevistados segundo componente curricular. São Paulo, 2006

FIGURA 6: Distribuição da proporção (\%) dos professores segundo tempo em anos de exercício da profissão. São Paulo, 2006.

FIGURA 7: Distribuição da proporção (\%) dos professores por nível de ensino no exercício do magistério. São Paulo, 2006.

FIGURA 8: Distribuição da proporção (\%) de professores segundo estado conjugal. São Paulo, 2006

FIGURA 9: Proporção (\%) de respostas dadas pelos professores de acordo com as Idéias Centrais da pergunta "O que é Fumar para você? Fala um pouco disso para mim" São Paulo, 2006.

FIGURA 10: Proporção (\%) de respostas dadas pelos professores de acordo com as Idéias Centrais da pergunta "Você acha que o cigarro afeta outras pessoas?" São Paulo, 2006.

FIGURA 11: Proporção (\%) de respostas dadas pelos professores de acordo com as Idéias Centrais da pergunta "E o aluno fumante, como é isto para você?"' São Paulo, 2006.

FIGURA 12: Proporção (\%) de respostas dadas pelos professores de acordo com as Idéias Centrais da pergunta "Você já participou de alguma atividade ligada ao tabagismo na escola? Fale um pouco sobre isso.” São Paulo, 2006....

FIGURA 13: Proporção (\%) de respostas dadas pelos professores de acordo com as Idéias Centrais da pergunta "Como poderia ser abordada a questão do tabagismo pelas escolas?" São Paulo, 2006

FIGURA 14: Proporção (\%) de respostas dadas pelos professores de acordo com as Idéias Centrais da pergunta "E sobre projetos relacionados ao tabagismo na escola, o que você acha disto?" São Paulo, 2006.

FIGURA15: Proporção (\%) de respostas dadas pelos professores de acordo com as Idéias Centrais da pergunta "Você quer falar mais alguma coisa sobre tabagismo?" São Paulo, 2006. 


\section{Lista de Tabelas}

Tabela 1:Distribuição em número e proporção (\%) dos professores segundo o número de filhos. São Paulo, 2006.

Tabela 2: Distribuição em número e proporção (\%) de professores segundo faixa etária dos filhos. São Paulo, 2006.

Tabela 3: Número e proporção (\%) de professores segundo renda mensal familiar em reais. São Paulo, 2006..

Tabela 4: Número e proporção (\%) das respostas dadas pelos Professores de acordo com as Idéias Centrais da pergunta "O que é Fumar para você? Fala um pouco disso para mim” São Paulo,2006.

Tabela 5: Número e proporção (\%) das respostas dadas pelos Professores de acordo com as Idéias Centrais da pergunta "Você acha que o cigarro afeta outras pessoas?" São Paulo, 2006.

Tabela 6: Número e proporção (\%) de respostas dadas pelos professores de acordo com as Idéias Centrais da pergunta "E o aluno fumante, como é isto para você?" São Paulo, 2006

Tabela 7: Número e proporção (\%) de respostas dadas pelos professores de acordo com as Idéias Centrais da pergunta "Você já participou de alguma atividade ligada ao tabagismo na escola? Fale um pouco sobre isso." São Paulo, 2006

Tabela 8:Número e proporção (\%) de respostas dos professores de acordo com as Idéias Centrais da pergunta "Como poderia ser abordada a questão do tabagismo pelas escolas?” São Paulo, 2006.....

Tabela 9: Número e proporção (\%) de respostas dos Professores de acordo com as Idéias Centrais da pergunta "E sobre projetos relacionados ao tabagismo na escola, o que você acha disto?" São Paulo, 2006.

Tabela 10: Número e proporção (\%) de respostas dos professores de acordo com as Idéias Centrais da pergunta "Você quer falar mais alguma coisa sobre tabagismo?" São Paulo, 2006. 


\section{Lista de Siglas}

ACT - Aliança de Controle do Tabagismo

ABRASCO - Associação Brasileira de Pós-graduação em Saúde Coletiva

AFUBRA - Associação dos Fumicultores do Brasil

CDC - Centro de Controle de Doenças

CEBES - Centro Brasileiro de Estudos de Saúde

CONPREV - Coordenação de Prevenção e Vigilância

CQCT - Convenção-Quadro para o Controle do Tabagismo

CRATOD- Centro de Referência de Álcool, Tabaco e Outras Drogas

DSC - Discurso do Sujeito Coletivo

GTSS- Global Tobacco Surveillance System

HTPC - Hora de Trabalho Pedagógico Coletivo

IBGE - Instituto Brasileiro de Geografia e Estatística

IDESP - Índice de Desenvolvimento da Educação do Estado de São Paulo

INCA - Instituto Nacional do Câncer

INCOR - Instituto do Coração

IPI - Imposto sobre Produto Industrializado

LDB - Lei de Diretrizes e Bases da Educação Nacional

MEC - Ministério da Educação

MS - Ministério da Saúde

OMS - Organização Mundial de Saúde

ONG - Organização Não-Governamental

OPAS - Organização Pan-Americana de Saúde

PAHO - Organizacion Panamericana de La Salud

PCN - Parâmetros Curriculares Nacionais

PDE - Plano de Desenvolvimento da Educação

PL - Partido Liberal

PNCT - Programa Nacional de Controle do Tabagismo

PQE - Programa de Qualidade das Escolas

PSDB - Partido Social Democrata Brasileiro 
SARESP - Sistema de Avaliação de Rendimento Escolar de São Paulo

SUS - Sistema Único de Saúde

UFRRJ - Universidade Federal Rural do Rio de Janeiro

UNESCO - Organização das Nações Unidas para a Educação, Ciência e Cultura

UNICEF - Fundo das Nações Unidas para a Infância

WHO - World Health Organization 


\section{ÍNDICE}

1.INTRODUÇÃO.

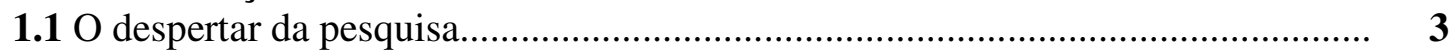

1.2 Tabagismo e suas implicações........................................................................ 5

1.3 Promoção da saúde................................................................................... $\quad 21$

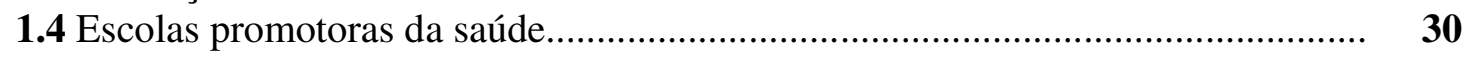

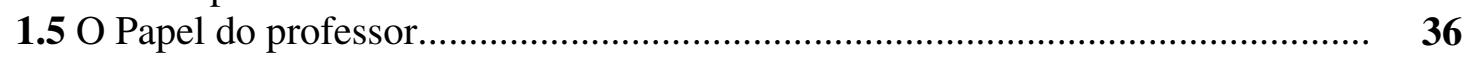

1.6 Tabagismo e promoção da saúde escolar............................................................... $\quad 40$

1.7 Representação social e tabagismo................................................................. 45

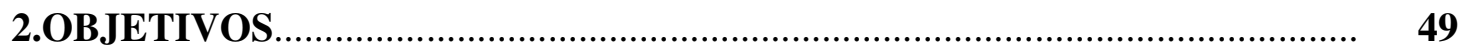

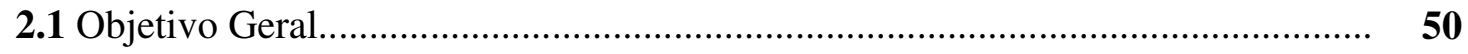

2.2 Objetivos Específicos.................................................................................... $\quad \mathbf{5 0}$

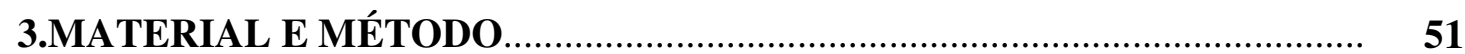

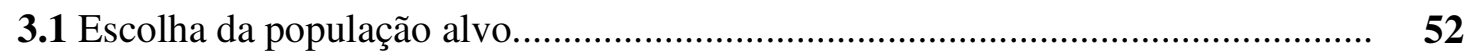

3.2 Procedimento metodológico...................................................................... $\quad 5$

4.RESULTADOS

4.1 Características dos entrevistados................................................................. $\quad 57$

4.2 Apresentação dos Discursos do Sujeito Coletivo................................................ $\quad \mathbf{6 5}$

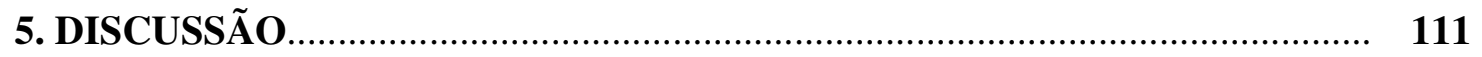

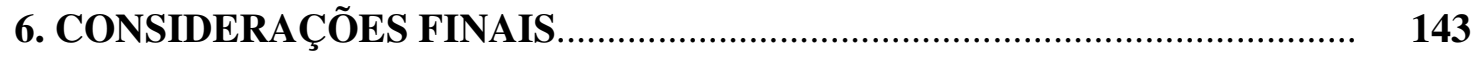

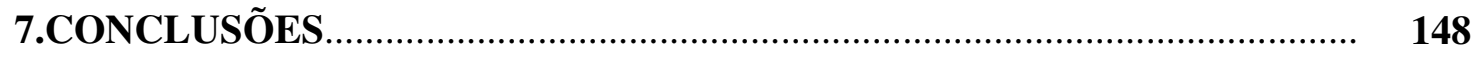

8. REFERÊNCIAS BIBLIOGRÁFICAS..................................................... 154

9. BIBLIOGRAFIA COMPLEMENTAR ..................................................... 165

10. ANEXOS

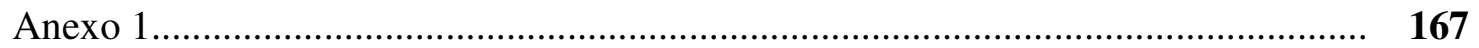

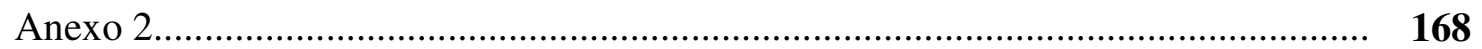

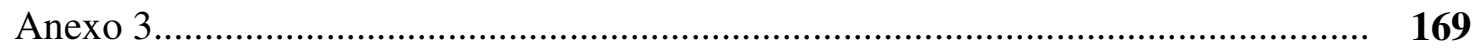

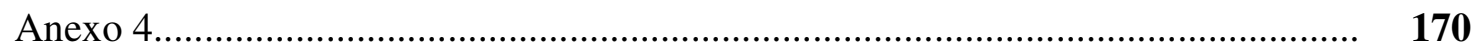

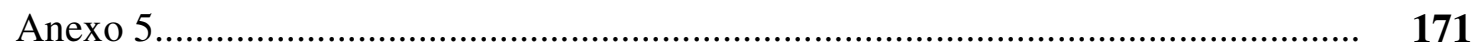

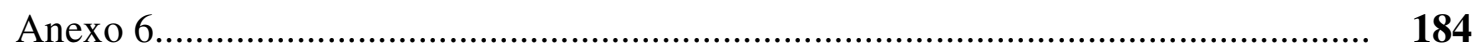

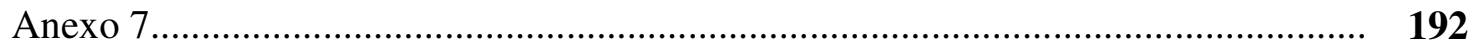




\section{INTRODUÇÃO}

"A verdadeira viagem da descoberta consiste não em buscar novas paisagens, mas em ter olhos novos" Marcel Proust 


\subsection{0 despertar da pesquisa}

O nosso primeiro contato com o tema tabagismo se deu durante a dissertação de mestrado, quando colhemos os Discursos do Sujeito Coletivo de mães que fazem dos seus filhos fumantes passivos. Esse trabalho provocou uma inquietação e originou questionamentos: Como a escola, meu ambiente afeiçoado e cotidiano de trabalho, poderia propiciar um avanço no controle do tabagismo entre os adolescentes? Como nossos professores, em sua prática carregada de intenções, ou não, poderiam contribuir na implementação do controle do tabagismo na escola?

A presença constate e empenhada durante nossa atuação na equipe de gestores da escola nos mostrou que esse ambiente rico de experiências, muitas vezes também se perde em meio às demandas do dia-a-dia e acaba traduzindo as dificuldades da gestão educacional e da docência, quando não revela a impotência diante da escassez do tempo que se esvai deixando a sensação de que pouco se fez em meio a tanto trabalho executado.

O desafio é, portanto, repensar e reconduzir as ações e seus paradigmas, para que a escola possa se aproximar do educando, que mais e mais recebe variados estímulos de uma sociedade "midiatizada".

Como bem ressalta ALARCÃO (2001), a escola é um lugar, um edifício circundado, espera-se, por alguns espaços abertos. Todavia, indaga a autora, os espaços abertos não estarão defasados em relação às concepções de formação, às formas de gestão curriculares e às exigências do relacionamento interpessoal? Há nela espaço de convívio, de desporto, de cultura, de trabalho em equipe, de experimentação?

Buscando apoio em reflexões dessa natureza, questionamos: Como o tabagismo poderia ser abordado na escola, sob os ares da promoção da saúde, de maneira a trazer maior benefício ao seu alunado e ao seu entorno?

Uma escola inovadora, que pensa a partir de si própria, isto é, uma escola reflexiva, aberta à comunidade do seu interior e do seu exterior, traz ao foco uma participação efetiva de todos os segmentos. E é nesse contexto que colocamos o papel do professor como um dos canais a ser investigado no controle do tabagismo entre os 
adolescentes, talvez pelo fato de ser o primeiro profissional a oferecer voz indicadora de novas formas de caminhar.

A importância da participação dos professores e a incorporação de suas idéias e representações já contam com o reconhecimento científico. Sendo assim, o professor é apontado como sujeito participante das propostas inovadoras e como requisito imprescindível ao sucesso da implementação de mudanças.

Muitas vezes, sua prática é questionada porque a pesquisa não se aproxima da sala de aula, ou ainda porque não é conhecido exatamente o ofício do professor, que também se apóia na prática dos seus alunos. É pertinente destacarmos que esse profissional não pode ser meramente treinado para executar as decisões tomadas por seus gestores de forma passiva, conformista e imutável. Ao contrário, os professores devem ser ouvidos, incentivados, mobilizados para a participação, reflexão e co-autoria na construção de novas iniciativas.

Quando destacamos a relevância da reflexão do professor, estamos fazendo uma aproximação com o conceito de Professor Reflexivo a partir das contribuições de SHÖN (1983) no contexto da formação desses profissionais. Conceito que, segundo PIMENTA e GHEDIN (2005), foi rapidamente disseminado por todo o país após o I Congresso sobre Formação de Professores nos Países de Língua e Expressão Portuguesas, realizado em Aveiro (Portugal), 1993.

Embora os autores argumentem que todo ser humano tem condições de refletir, desde o início dos anos 1990 a expressão Professor Reflexivo tomou conta do cenário educacional, confundindo a reflexão enquanto adjetivo, como atributo próprio do ser humano, com um movimento teórico de compreensão do trabalho docente.

Porém, para esclarecer a diferença entre a reflexão como atributo dos professores e o movimento que trouxe o conceito de Professor Reflexivo, é necessário retomarmos a linha de desenvolvimento de SCHÖN (op cit). O autor propõe uma formação profissional baseada numa epistemologia da prática, ou seja, na valorização da prática profissional como momento de construção do conhecimento.

Embora a reflexão, traduzida em conhecimento na ação, seja interiorizada e mobilizada pelo professor no seu dia-a-dia, tornando-se um hábito, ainda assim não é 
suficiente. Esse conhecimento constrói um repertório de experiências configurando um conhecimento prático, mas que não substitui totalmente a busca de possíveis explicações para a solução de problemas e análise do cotidiano tão multifacetado do ambiente escolar.

Com a construção dos Discursos do Sujeito Coletivo pretendemos, portanto, buscar subsídios para a análise das representações sociais dos professores sobre o tabagismo, mesmo que eles nem sempre tenham se ocupado especificamente com o tema em sala de aula. O reconhecimento dos contextos nos quais emergem essas representações, as comunicações que circulam entre os professores e as interações com o mundo e seu ambiente poderão se constituir em requisito indispensável para a base das ações de promoção da saúde e no controle do tabagismo em escolares.

\subsection{Tabagismo e suas implicações}

Os prejuízos causados aos fumantes e não fumantes pelo efeito dos componentes presentes no tabaco vêm sendo apontados nos discursos de pesquisadores de todo o mundo.

Os fumantes existentes no mundo no início do século XXI chegam a 1,3 bilhão, decorrendo desse fato a morte de cinco milhões de pessoas ao ano devido ao consumo de tabaco (MINISTÉRIO DA SAÚDE/INCA, 2004).

A Organização Mundial de Saúde (OMS) estima que, caso não haja controle mundial na exposição ao tabaco, em 2030 o número de fumantes crescerá para 1,6 bilhão (WHO, 2004).

No Brasil, o tabagismo é apontado como segundo fator mais importante de risco de óbito, com 200 mil mortes anuais, sendo suplantado apenas por hipertensão (Silva apud MS/OPAS, 2004, p. 37).

As manifestações de seus efeitos aparecem traduzidas em doenças crônicas pulmonares, cardíacas e outros tantos agravos, não só entre fumantes como também entre não-fumantes, podendo se refletir, ainda, à próxima geração. 
Apenas $6,7 \%$ dos casos de câncer de pulmão, uma das principais causas de morte básicas não violentas no Brasil, não estão relacionados ao cigarro, já que 93,3\% ocorrem em fumantes (MS/INCA, 2004).

$\mathrm{Na}$ maioria das vezes, o cigarro ainda leva à morte por doença coronariana (obstrução das artérias do coração), bronquite e enfisema, outros tipos de câncer (de boca, laringe, faringe, esôfago, pâncreas, rim, bexiga e colo de útero) e doenças vasculares (entre elas, derrame cerebral e obstrução na circulação das pernas) (ROSEMBERG, 1987).

O tabagismo trata-se de um hábito que pode causar também impotência sexual no homem, complicações maternas e fetais na gravidez, úlcera do aparelho digestivo, infecções respiratórias e trombose vascular, podendo culminar com amputação de extremidades e membros inferiores (MUST et al, 2004).

O longo período entre o início do tabagismo e o aparecimento de sintomas (podendo levar de 10 a 30 anos), denominado período de incubação, faz com que muitas pessoas se sintam seguras fumando ou ainda não dêem a devida atenção ao risco que correm.

Nas quinze funções químicas existentes no fumo, DUBE E GREEN (1982), identificaram no tabaco 4.720 elementos como: óxidos, radicais livres, peróxido de hidrogênio, hidroxila e superóxidos, que, além de serem extremamente tóxicos para as células, inativam as enzimas.

Dados mais recentes, do estudo liderado por BAKER e col. (2000), apontam no tabaco cerca de 6.700 substâncias, das quais 63 são cancerígenas e onze destas comprovadamente carcinogênicas humanas.

Nos Estados Unidos, o Centro de Controle e Prevenção de Enfermidades Center for Disease Control and Prevention - revelou ainda que os fabricantes de cigarro, para dar sabor ao produto, utilizam perto de 700 aditivos como: mentol, cacau, melaço, canela, anis, cravo, passas, figo, cereja, folhas de chá, chocolate, café, gengibre, rum, água, levedura, limão, maçã, caramelados. Além disso, acrescentam outros componentes químicos que contribuem para a eliminação de um número ainda maior de sustâncias no ambiente associadas à queima do tabaco. 
De fato, os tóxicos do cigarro produzem na cadeia metabólica produtos terminais chamados glicotoxinas, que, ao reagir por ligação cruzada com as proteínas, provocam efeitos mutagênicos no DNA (ácido desoxirribonucléico), podendo induzir ao câncer e às neoplasias em geral.

As glicotoxinas também contribuem para o envelhecimento precoce, catarata, arteriosclerose, insuficiência renal, retinopatias e diabetes. Portanto, sendo indutor do efeito mutagênico e promotor de multiplicação de células, o fumo é considerado um cancerígeno completo (ROSEMBERG, 2003).

O cigarro é, portanto, um poluente individual muito mais nocivo que a própria poluição urbana: um milímetro de fumo proveniente de um só cigarro cria no ambiente do fumante uma atmosfera cuja densidade de poluentes supera as maiores concentrações encontradas entre os demais poluentes urbanos (ZLOTINIK e col., 1985).

O hábito de fumar, apesar de socialmente aceito, transforma grande parcela da população em fumante involuntária, expondo-a a quantidades expressivas de substâncias nocivas à saúde. O fumante passivo, portanto, é o indivíduo que se expõe involuntariamente à fumaça do cigarro nos mais variados ambientes sociais, até mesmo em sua própria casa, quando convive com fumantes (HILLMAN et al, 1993).

A OMS afirma que o tabagismo, considerado doença crônica, é a maior causa isolada evitável de doença e de morte e o insere na Classificação Internacional de Doenças (CID 10) como "uma desordem mental e de comportamento em razão da síndrome da dependência à nicotina" (OMS, 1993; Moraes, 2006, p.8).

Ainda segundo a OMS, "O controle do hábito de fumar cigarros fará mais pela saúde do homem e sua expectativa de vida, do que qualquer outra opção de Medicina Preventiva" (WHO apud ZLOTINIK e col., 1985, p.314).

Podemos concluir então que o uso do fumo representa um grande risco à saúde $\mathrm{e}$ merece imediata ação dentro da perspectiva das políticas públicas voltadas à saúde, sendo o seu controle uma questão ética de responsabilidade social. 


\section{Cultura do tabaco e seus malefícios}

Os malefícios causados pelo fumo não decorrem apenas do consumo direto, mas também, em grandes proporções, de sua cultura e beneficiamento, com conseqüências sérias sobre o homem e o ambiente.

O desmatamento, por exemplo, decorre principalmente da utilização da lenha para a cura da folha de tabaco, sendo que, em nosso país, há cerca de 120 mil fornos com essa finalidade (AFUBRA, 2001).

A derrubada sistemática da mata nativa contribui para a ocorrência de erosão e destruição do solo, que se torna exposto às chuvas fortes e à insolação, sofrendo assim conseqüente empobrecimento (ROCHA, 2001).

Outro aspecto importante diz respeito à contaminação do ambiente e à esterilização do solo devido ao uso abusivo de pesticidas, fertilizantes e outros agrotóxicos nas plantações de tabaco. Para obter bom preço no mercado, por exemplo, as folhas de tabaco devem ser grandes e isso requer o uso de desbrotantes, produto que mata os brotos e força a planta a só crescer por meio das folhas já existentes. Esse tipo de produto, além de ser carregado por fenômenos naturais a outros ambientes, conduz à contaminação de toda a cadeia alimentar, rompendo o equilíbrio do ecossistema (ROCHA, 2001).

A cultura do fumo utiliza, ainda, agrotóxicos conhecidos como organofosforados e ditiocarbamatos, considerados pelos pesquisadores como prováveis causadores de doenças neurocomportamentais, como depressão e suicídio ( UFRRJ/instituto 2007).

Além desses agroquímicos, dados do Instituto Brasileiro de Geografia e Estatística (IBGE) referiram que, em 1995, foram utilizadas 236.000 toneladas de fertilizantes na cultura de fumo em nosso país (LAPATE, 2001).

E há que se destacar também a utilização de crianças como mão-de-obra no cultivo familiar na lavoura do tabaco, que, associada à ausência de orientação para o uso de fertilizantes e pesticidas, expõe indivíduos nessa faixa etária precocemente não apenas ao tabagismo passivo como também à ação química tóxica. No Brasil, é estimado em 520.000 o número de jovens menores de 18 anos que são expostos diretamente aos 
agrotóxicos e à absorção da nicotina pela pele durante a colheita, originando a conhecida "doença do tabaco verde" (MS/OPAS, 2004).

Ainda sob o ponto de vista da ocupação do solo, além de provocarem sua esterilização, as plantações de tabaco são instaladas em áreas que competem no plantio de culturas mais nobres, como as de produção de alimentos ou de produtos de consumo oriundos da pecuária.

\section{Paralelo entre perfil do consumidor e produção do fumo}

Se no cenário mundial o consumo de cigarros vem caindo na maioria dos países desenvolvidos, o seu consumo global aumentou em torno de $50 \%$ durante o período de 1975 a 1996, principalmente, devido ao aumento observado nos países mais pobres, particularmente na Ásia e na África.

Atualmente, $80 \%$ de fumantes no mundo vivem em países em desenvolvimento e $80 \%$ dos 100000 jovens que se iniciam a cada dia provêm de países pobres (WORLD BANK, 1999).

Na maioria dos países existe uma correlação entre tabagismo, baixa renda e baixo nível de escolaridade. Na China e no Brasil, por exemplo, indivíduos com nenhuma escolaridade têm uma probabilidade de se tornarem fumantes cerca de sete e cinco vezes maior, respectivamente, do que os estudantes do $3^{\circ}$ grau (WORLD BANK, 2003).

No Brasil, no início de 2002, a prevalência do tabagismo entre as pessoas com renda igual ou menor a dois salários mínimos foi de $23,5 \%$, ao passo que a prevalência de fumantes entre os que recebiam acima de 20 salários era de 16,5\% (Figueiredo et al, 2002 apud BRASIL-MS/OPAS, 2004, p. 103).

Nessa época, a maior produção de fumo se concentrou no sul do Brasil. A safra de 2001/2002 na região foi de 633 mil toneladas de fumo, representando 96,4\% do total da produção brasileira. O Estado de Santa Catarina representou 34\% do total produzido e o Paraná respondeu por $11 \%$. 
A produção de estados da região Nordeste, entre eles Alagoas, Bahia, Sergipe, atingiu 24 mil toneladas, o equivalente a 3,6\% do total no Brasil (Deser, 2003 apud MS/OPAS, 2004, p. 111).

Durante décadas, segundo NARDI (2003),

[Arapiraca (Alagoas)] viveu ao ritmo da lavoura do fumo. Na cidade, nas praças do centro, os produtores se reuniam para vender suas bolas... Em inúmeras ruas havia salões cheios de mulheres e crianças destalando fumo e cantando; os rolos ficavam à mostra nas calçadas; os armazéns das exportadoras estavam abarrotados de folhas; a cidade toda cheirava a fumo... Isso contribuiu para manter o espírito rural na cidade (p. 27).

Até o final do século XX, o fumo foi então a principal atividade econômica de Arapiraca. Em 1998, o setor entrou numa crise estrutural anunciando o fim dessa cultura. Arapiraca, portanto, está passando hoje por um importante momento de sua história. A crise e o fim previsível da cultura fumageira, decorrentes da mobilização mundial de controle do tabagismo, vão obrigar a população a adotar outros caminhos para obtenção de renda e superar as primeiras conseqüências socioeconômicas no seu município e região.

Já na região sudeste, mais especificamente no município de São Paulo, o decréscimo do tabagismo pode ser observado comparando-se dados da literatura sobre a prevalência desse hábito. Em 1971, relatou-se para a faixa etária de 15 a 74 anos prevalência de fumantes de 54,8\% em homens e de 20,9\% em mulheres. Em 2002-2003, o Inquérito Domiciliar sobre Comportamentos de Risco e Morbidade Referida de Doenças e Agravos não Transmissíveis, estudando indivíduos com mais de 15 anos de idade, mostrou prevalência de tabagismo de 23,1\% em homens e $17,5 \%$ em mulheres, em amostra de 1.210 indivíduos, confirmando a tendência de redução do tabagismo em ambos os sexos (MARCOPITO et al, 2007).

A presença de irmãos e amigos tabagistas esteve fortemente associada à experimentação e ao fumo atual de estudantes. A influência de grupos de indivíduos fumantes com a mesma faixa etária do adolescente é particularmente forte nas fases 
iniciais de uso do tabaco, pois as primeiras tentativas de experimentar cigarros ocorrem freqüentemente com os irmãos e amigos, e estes podem prover expectativas, reforço e sugestões subseqüentes favoráveis à manutenção do hábito. Diversos estudos sobre tabagismo na adolescência são unânimes em apontar essas associações (MALCON et al, 2003).

\section{Ações preventivas para promoção da saúde}

No cenário mundial, os Objetivos para o Desenvolvimento do Milênio propõem aos países a inclusão do controle do tabagismo como importante aspecto de desenvolvimento social.

Problemas dessa natureza podem ser abordados, em todo o mundo, desenvolvendo-se ações de promoção da saúde que reflitam medidas mais abrangentes e que superem a concepção clínico-assistencial para questões de saúde-doença na sociedade. Além disso, a promoção da saúde recebe destaque por reunir elementos de diversas fases e origens da evolução do conceito de saúde e sociedade. Com o mérito de dirigir um olhar multifacetado às condições de vida da população, conta com um consenso político entre todos que habitualmente conduzem as pesquisas científicas em saúde (MINISTÉRIO DA SAÚDE, 1996).

Sob esse olhar, o tabagismo é destacado, ainda, com um alerta aos governos para o elevado potencial humano perdido por doenças e mortes causadas pelo uso do fumo, além da adequada conservação dos recursos naturais e proteção do ecossistema, que, como vimos, sofrem com o cultivo do tabaco.

As conferências de Promoção da Saúde em Otawa (1986) no Canadá, Adelaide na Austrália (1988) e Sundsvall na Suécia (1991) reafirmaram e desenvolveram os campos de ação da promoção da saúde no mundo e trouxeram o tabagismo para essa reflexão.

As nações latino-americanas incorporaram significativos aportes de reuniões internacionais anteriores para elaborar conclusões na Conferência Internacional em Promoção da Saúde realizada em Santa Fé de Bogotá (1992). 
$\mathrm{Na} 4^{\mathrm{a}}$ Conferência sobre Promoção de Saúde que aconteceu em Jacarta na Indonésia, a primeira a ter lugar em um país em desenvolvimento, após quase 20 anos da Declaração de Alma Ata, o setor privado foi incluído (MINISTÉRIO DA SAÚDE,2001), sendo apontados, ainda, novos determinantes da saúde como desafios. Ficou claro o quanto é vital a evolução da promoção da saúde para fazer frente a eles. Ainda nessa Conferência, foi destacado que, ao mesmo tempo em que algumas mudanças conferem um grande potencial para a saúde, como a tecnologia das comunicações, outras, como o comércio internacional do tabaco, têm um impacto negativo.

Com o crescimento do consumo de tabaco no mundo, fez-se necessário incrementar ações preventivas, surgindo assim, durante a 52 ${ }^{\mathrm{a}}$ Assembléia Mundial da Saúde, um órgão de negociação intergovernamental para redigir e negociar o Projeto da Convenção-Quadro para o Controle do Tabagismo (CQCT), resultado de mais de dois anos de intensos esforços de negociações sob a presidência brasileira. Aprovado por 192 países até 2003, o tratado fixa padrões internacionais para o controle do tabaco com providências relacionadas a diversos setores do contexto tabágico atual. Uma vez em vigor, a CQCT é o primeiro tratado internacional negociado sob os auspícios da OMS, instrumento único e inovador que visa proteger as gerações futuras das devastadoras conseqüências à saúde e ao ambiente da exposição à fumaça e do consumo do tabaco.

O texto da CQCT também é singular por conter uma combinação adequada de obrigações gerais e princípios orientadores que não precisa esperar por protocolos específicos para alcançar seus objetivos de redução e exposição ao tabagismo, embora deva ser assistida por protocolo específico sobre comércio ilícito e propaganda transfronteiriça (Adede apud MS/OPAS, 2004, p.92).

Uma das grandes barreiras para que os países adotassem, assinassem e ratificassem a Convenção-Quadro foi o forte lobby das grandes companhias transnacionais de tabaco, que procuram trabalhar patrocínios, propagandas e eventos direcionados principalmente ao público jovem.

Apesar de o Brasil ter sido o segundo país a assinar a Convenção-Quadro, sua ratificação só aconteceu em 27 de outubro de 2005. O acordo aprovado no Senado 
ocorreu a apenas onze dias do prazo final estipulado pela OMS (sete de novembro) para qualquer país depositar a ratificação da Convenção na Organização das Nações Unidas (ONU). A adesão do nosso país ao tratado pôs fim a uma acirrada disputa entre defensores da saúde pública, entre eles o Instituto Nacional do Câncer (INCA), coordenador do Programa Nacional de Controle do Tabagismo, e alguns setores da indústria do tabaco no Brasil, reforçando a mensagem: "não sobrepomos aos interesses de saúde pública os interesses econômicos ou comerciais" (pronunciamento do Ministro da Saúde Humberto Costa durante o Seminário sobre a CQCT, em 27 de agosto de 2003).

Com essa decisão, o país tornou-se o $100^{\circ}$ país a ratificar o tratado, garantindo assim a participação na primeira sessão da Conferência das Partes, realizada em fevereiro de 2006. Dessa forma, pôde usufruir de apoios internacionais, técnicos e financeiros para o fortalecimento de uma política agrícola de alternativas ao fumo e assim beneficiar as 200 mil famílias que hoje dependem do plantio de tabaco.

O longo período de espera para a ratificação instalou-se na contramão das ações de um país com tanta história de sucesso no controle do tabagismo. O país que implantou restrições à propaganda de cigarro, proibiu o tabagismo em muitos locais públicos, traz fortes advertências ao consumo nos maços de cigarro, além de outras tantas medidas apoiadas em uma legislação firme, não poderia ficar à margem das propostas da CQTC.

Hoje, a ratificação por países que envolvem mais de $70 \%$ da população mundial, totalizando 161 adesões até novembro de 2008, fortalece a disposição de garantir o funcionamento desse tratado.

O ano de 2005, apesar dos momentos de tensão, foi de grandes conquistas para o controle do tabagismo no Brasil. Além da ratificação da Convenção-Quadro para o Controle do Tabaco pelo Congresso Nacional, observamos diversas iniciativas de incorporação de ações necessárias ao controle do tabagismo por muitos setores governamentais, demonstrando o efetivo comprometimento do governo brasileiro com essa questão. 
No campo da saúde, o controle do tabagismo foi assumido como importante ferramenta de promoção da saúde e citado nominalmente em diversas portarias ministeriais, tais como:

- Portaria $\mathrm{N}^{\mathrm{o}}$ 1.105/GM de cinco de julho de 2005 (MINISTÉRIO DA SAÚDE/PORTARIA,2005a) reiterada pela Portaria No 2.084 (MINISTÉRIO DA SAÚDE/PORTARIA,2005b) de outubro do mesmo ano, que incorporou os medicamentos utilizados no apoio à abordagem congnitivo-comportamental do fumante no componente estratégico do Elenco de Medicamentos para Atenção Básica, passo fundamental no processo de consolidação da atenção ao fumante no Sistema Único de Saúde.

- Portaria $\mathrm{N}^{\circ}$ 2.439/GM, que lançou em oito de dezembro de 2005 (MINISTÉRIO DA SAÚDE/PORTARIA,2005c) a Política Nacional de Atenção Oncológica, englobando as diretrizes de promoção, prevenção, diagnóstico, tratamento e cuidados paliativos a serem implementados em todas as unidades federadas. Além de citar em seu artigo terceiro, inciso VII, o Plano de Controle do Tabagismo como componente fundamental da política, esta portaria aponta para a necessidade de desenvolvimento de estratégias que ampliem os modos de viver mais favoráveis à saúde e à qualidade de vida e a identificação dos determinantes e condicionantes das principais neoplasias malignas, estando aqui incluídos não só o tabagismo, como também outros fatores de risco, como a obesidade e o sedentarismo.

- Portaria No 2608/GM, em 28 de dezembro de 2005 (MINISTÉRIO DA SAÚDE/PORTARIA,2005d), que definiu recursos financeiros do Teto de Vigilância em Saúde com vistas a incentivar a estruturação de ações de vigilância e prevenção de doenças e agravos não-transmissíveis, considerando, entre outras, o fomento a ambientes livres do tabaco e o incentivo às ações de estímulo a uma alimentação saudável e à prática de atividade física. 
No início do ano 2006, duas novas portarias citam o controle do tabagismo no corpo das ações propostas. Em fevereiro, a Portaria No 399/GM (MINISTÉRIO DA SAÚDE/PORTARIA, 2006a) divulgou o Pacto pela Saúde 2006, e em março, a Portaria No 687 (MINISTÉRIO DA SAÚDE/PORTARIA,2006b) aprovou a Política de Promoção da Saúde. Na primeira, a promoção da saúde, com ênfase no estímulo à prática de atividades físicas, adoção de alimentação saudável e controle do tabagismo, foi apresentada como prioridade do Pacto pela Vida. Na Política de Promoção da Saúde, a prevenção e o controle do tabagismo ganharam um capítulo em separado entre as ações específicas, sendo nele delineadas todas as diretrizes que nortearam a implementação do Programa Nacional de Controle do Tabagismo e Outros Fatores de Risco de Câncer.

O INCA, responsável por desenvolver o referido programa de Controle do Tabagismo, utiliza as três instâncias governamentais - federal, estadual e municipal para treinar e apoiar os 5.527 municípios brasileiros no gerenciamento e desenvolvimento das ações nas áreas da educação, legislação e economia. Suas atuações educativas estão divididas em ações pontuais, campanhas de comunicação de massa, como as desenvolvidas durante as datas comemorativas do Dia Mundial Sem Tabaco (31 de maio), criado pela ONU, Dia Nacional de Combate ao Fumo (29 de agosto) e Dia Nacional de Combate ao Câncer (27 de novembro), bem como ações contínuas, que utilizam unidades de saúde, escolas e ambientes de trabalho como canais para atingir os públicos-alvos.

No Brasil, as constantes parcerias junto às Secretarias Estaduais e Municipais de Saúde, Agência Nacional de Vigilância Sanitária, Organizações Governamentais e NãoGovernamentais têm proporcionado o desenvolvimento de ações nacionais para sensibilizar e mobilizar a população brasileira para os danos sociais, políticos, econômicos e ambientais ocasionados pelo tabaco.

A abrangência de todo o território brasileiro para o Programa Nacional de Controle do Tabagismo (PNCT) busca ser garantida pela organização de uma rede nacional de gerenciamento regional que, através da sua coordenação estadual, promove ações descentralizadas para seus municípios. 
As ações legislativas do INCA envolvem o apoio técnico a processos e projetos de lei, o monitoramento da legislação e a informação sobre os malefícios do tabaco e outros fatores de risco de câncer aos membros do Congresso Nacional.

O estudo econométrico, com dados sobre produção, preços, publicidade, consumo e arrecadação relacionados com o tabaco e seus derivados no Brasil, desenvolvido pelo mesmo órgão, busca servir de subsídio às decisões governamentais nas áreas de saúde, legislação e na própria área econômica, como incentivo à redução do consumo no país.

O referido órgão pretende ainda, além de divulgar e apoiar o Programa Nacional para o Controle do Tabagismo, promover e divulgar o desenvolvimento e a adoção da Convenção Quadro Internacional para o Controle do Tabaco, proposta pela Assembléia Mundial de Saúde.

No contexto mundial, a OMS, que propôs o dia 31 de maio para a comemoração do Dia Mundial sem Tabaco, nesta data conta com a participação de 192 países membros da organização, com a proposta de sensibilizar a comunidade em geral sobre os malefícios do consumo dos produtos derivados do tabaco. Tem como proposta, ainda, divulgar e reforçar as leis que restringem o uso do tabaco em ambientes fechados e estimular os principais empregadores a converterem suas empresas em ambientes livres de tabaco.

O tema "Juventude Livre do Tabaco", escolhido para celebração do Dia Mundial sem Tabaco em 2008, permitiu que os Estados-Membros da OMS desenvolvessem atividades fortalecendo a necessidade do controle do tabagismo em todo o mundo. $\mathrm{Na}$ ocasião, cada membro adaptou sua campanha à realidade socioeconômica e cultural de seu país, respeitando a peculiaridade de cada povo.

Por ser um hábito que se contrapõe ao pensar da Promoção da Saúde, o controle do tabagismo é hoje compartilhado por todos aqueles que acreditam na necessidade de, para se ter saúde, não só mudar as condições de vida, mas também atuar sobre os determinantes da saúde. 


\section{Como se contrapor às ações da indústria do fumo?}

A conscientização da população frente até mesmo às ações da indústria do fumo, que, muitas vezes, elegem atividades específicas para determinados países e buscam a todo custo aumentar o consumo, precisa ser incentivada.

Os esforços da forte indústria brasileira de fumo em contratar cientistas e consultores para mostrar que não há prejuízo frente à exposição à fumaça ambiental (tabagismo de segunda mão), ou que ele é insignificante, devem ser entendidos como contrários ao manifesto mundial de controle de tabagismo.

$\mathrm{O}$ interesse da indústria em, rotineiramente, realizar pesquisas entre os jovens focalizando campanhas de marketing voltadas a indivíduos dessa faixa etária precisa causar indignação.

As pesquisas mostram que é na adolescência que o jovem experimenta e se torna fumante: $90 \%$ dos fumantes começaram com o hábito antes dos 19 anos. Seduzir os jovens sempre fez parte de uma estratégia adotada por todas as companhias de tabaco para manter seus mercados.

A própria indústria assumiu em seus relatórios internos que são os jovens fumantes que repõem os mais velhos que deixam de fumar ou morrem (ACTbr/ 2007).

O sucesso na redução do tabagismo também depende de compreender a indústria do fumo e se contrapor a sua influência; e foi com esse olhar que a Organização PanAmericana de Saúde (OPAS) publicou, em 2001 o documento Profits Over People. Este relatório é fruto de uma investigação de documentos internos das indústrias de cigarro e mostra que, embora pareçam totalmente rivais na disputa de mercado, as empresas de fumo também trabalham juntas para combater as ameaças aos seus interesses comuns, isto é, contra tudo que pode acarretar uma redução efetiva do tabagismo.

O relatório Profits Over People aponta as estratégias usadas pela indústria de cigarro na América Latina e Caribe para prevenir ações contra o tabagismo, tais como: negar as evidências da ligação do tabagismo passivo a várias doenças; apontar o tabagismo passivo como um componente menor da contaminação do ar; promover as áreas de "acomodação" para fumantes e não-fumantes como um direito do tabagista, 
desconsiderando a dispersão dos poluentes pelo ar ou sistemas de ventilação (Selin apud MS/OPAS, 2004, p. 63).

Outra influência da indústria do tabaco também se evidencia quando cria mitos sobre perdas econômicas dos países na arrecadação de imposto, perda de emprego e destino dos fumicultores no controle do tabagismo.

O descrédito dessa alegação pode ser enfatizado por dados de pesquisas do Banco Mundial, os quais apontam uma perda global de US\$ 2 bilhões por ano em função de incapacitações, adoecimentos, custos de aposentadorias (invalidez, auxílio doença e pensões), além de perdas na produção por absenteísmo e perdas econômicas pela degradação ambiental (WORLD BANK, 2003).

A preocupação de aprofundar as discussões internacionais no assunto levou o Banco Mundial a analisar as ações de controle do tabagismo, concluindo que o potencial de arrecadação por meio dos impostos do setor tabaco depende de vários fatores, tais como: nível de consumo, preço no varejo e imposto total por maço, baixas oportunidades de substituição, elasticidade-preço e elasticidade-renda dos produtos de tabaco e o controle das atividades de contrabando.

No Brasil, estudos mostraram que o preço é inelástico, já que um aumento de $10 \%$ na média de preço do cigarro no varejo pode reduzir o consumo entre $4 \%$ e $5 \%$. Populações de baixa renda podem se ressentir do aumento nos preços; porém, por se tratar de um produto que causa dependência e de difícil abandono, isto gera um impacto em longo prazo na saúde e na economia dessas famílias, tornando-se assim necessário encorajar a procura de centros de ajuda de cessação para aqueles que querem parar de fumar.

No entanto, a renda da população cresceu no início deste novo século XXI, e o preço do cigarro aumentou menos que os preços de outros bens, permitindo que os fumantes adquiram mais cigarros dentro do seu orçamento. Essa facilidade econômica, acompanhada da falta de uma mudança na política de preços, poderá acarretar, em um período de 10 a 15 anos, um aumento de câncer de pulmão e de algumas das doenças crônicas associadas (INCA, 2004). 
Apoiados em estudos internacionais, economistas brasileiros compartilham a opinião da OMS e de órgãos não governamentais, como a Aliança de Controle do Tabagismo (ACT), e defendem um aumento do imposto seletivo sobre cigarro, como o Imposto sobre Produto Industrializado, (IPI)-Cigarro, por ser a maneira mais direta de aumentar o preço desse produto. Este por sua vez, poderá contribuir, mesmo que com pequeno impacto, para a redução do consumo. Finalmente, reduzindo o consumo, o país reduz a mortalidade e a morbilidade por doenças crônicas associadas ao tabagismo.

Outro bom fundamento é um estudo que o Banco Mundial preparou sobre o tema - "Curbing the Epidemic: Governments and the Economic of Tobacco Control". Nele, há exemplos de investigações empíricas que mostram a eficácia do aumento do preço na redução do consumo ( ACTbr/ 2008).

Em continuidade às ações de controle do tabagismo em nosso país, foi realizado em setembro de 2007, no Rio de Janeiro, o "Fórum Tabagismo Passivo e Legislação sobre ambientes livre de fumo no Brasil", com a proposta de alinhar a legislação nacional sobre tabagismo passivo às diretrizes da Convenção-Quadro para o Controle do Tabaco. O fórum teve a participação de diversos representantes de vários segmentos da sociedade civil organizada e do governo, e aprovou documento, solicitando a alteração da Lei Federal 9.294/96, que admite a existência de áreas específicas aos fumantes em bares, restaurantes e outros locais públicos.

Em Genebra, sede da Organização das Nações Unidas na Europa e de uma série de bancos internacionais, também existe uma mobilização para proibir o fumo em locais públicos após referendo realizado entre seus moradores, em 2008. Cerca de $80 \%$ dos eleitores da segunda maior cidade da Suíça apoiaram a proibição. A Suíça estava atrás de outros países europeus, como Irlanda, Inglaterra, França e Itália, na proibição do fumo em restaurantes, bares e escritórios. Fumar é proibido em transportes públicos suíços há dois anos.

Essas mobilizações devem ganhar apoio irrestrito, já que a OMS tem pedido a governos do mundo todo para protegerem seus cidadãos dos riscos causados à saúde pelo fumo. 
Recentemente, em publicação dos dados levantados sobre a Epidemia Global do Tabaco - MPOWER Package (2008) - a OMS destacou que, abraçando efetiva mobilização no controle do tabagismo, estaremos agindo sobre o fator de risco de seis entre as oito doenças de maior causa de morte no mundo (Doenças do Coração, Respiratórias e Câncer do Pulmão). Segundo Margaret Chan, atual Diretora Geral da OMS, o tabagismo não depende exclusivamente da atuação da medicina ou da adoção de vacinas, mas sim da ação conjunta de governos e sociedade civil (WHO, 2008).

As propostas de ação desse relatório envolvem a atuação na oferta de ajuda ao fumante para cessação, advertência dos prejuízos do consumo em embalagens de cigarro, proibição da publicidade e patrocínio das empresas produtoras de cigarro, além de elevação de impostos sobre produtos e derivados do tabaco.

No MPOWER Package (2008), o Brasil aparece com prevalência de tabagismo estimada em 17,2\% e 15,7\% para meninos e meninas, respectivamente, em idade de 13 a 15 anos no Rio de Janeiro. Para grupos acima de 18 anos, foram apontadas as taxas de 20,3\% para os homens e 12,8\% para as mulheres, dados extraídos da VIGITEL BRASIL (2006), Vigilância de Fatores de Risco e Proteção a Doenças Crônicas por Inquérito Telefônico (WHO, op. cit.).

Quando executadas e implantadas como pacote, as políticas de MPOWER protegerão jovens de iniciar o consumo de tabaco, ajudarão adultos a parar de fumar, além de proteger não-fumantes da exposição à fumaça do cigarro.

Pesquisas mostram que $80 \%$ dos fumantes desejam parar de fumar, mas apenas $3 \%$ conseguem a cada ano, sendo que, destes, a maioria consegue sozinho, sem qualquer ajuda (CINCIPRINI, 1997).

SZKLO e OTERO (2008), comparando os perfis de fumantes recrutados para um estudo de intervenção para cessação de fumar com os da população geral de fumantes no município do Rio de Janeiro, nos anos 2002-2003, concluíram ser fundamental compreender que os fumantes não são iguais e que há aqueles que precisam ser conquistados como "potenciais clientes" de programas de intervenção voltados às suas necessidades específicas. As heterogeneidades encontradas indicam que diferentes 
estratégias de captação associadas às intervenções existentes devem ser elaboradas para motivar o maior e mais diversificado número possível de indivíduos elegíveis.

Assim, associado a essa abordagem e ampliando o olhar sobre uma ação educativa, pode estar o professor propiciando reflexões sobre o hábito de fumar em seu ambiente de trabalho, foco de atenção desta tese.

\subsection{Promoção da saúde}

O movimento de Promoção da Saúde surgiu formalmente no Canadá, em 1974, com a divulgação do documento A New Perspective on the Health of Canadians, também conhecido como Informe Lalonde (BUSS, 2000, p. 167). Nele destacavam-se quatro componentes na determinação dos níveis de saúde da população representados por: organização da assistência, biologia humana, meio ambiente e estilo de vida, sugerindo também que o foco nos serviços de assistência não era a melhor forma de investir recursos públicos, com vistas à promoção da saúde.

Os crescentes aumentos nos investimentos tecnológicos e na assistência médica, segundo ROBERTSON (1998), motivaram a análise do custo-benefício da rede de atenção à saúde, instalada como parte da política pública de bem-estar canadense, agregada ainda aos resultados pouco significativos da abordagem exclusivamente médica para as doenças crônicas.

$\mathrm{Na}$ época, um novo paradigma se esboçava, formalizado na Conferência de Alma-Ata (1978), com a proposta "Saúde para Todos no ano 2000". Essa conferência aponta para a produção da concepção de promoção de saúde como um primeiro rompimento com os princípios da assistência sanitária tradicional; com isso, a OMS passa a estimular a reflexão dos países sobre a eqüidade e a justiça social frente à saúde.

Durante as décadas que se sucederam, com o aumento da pobreza e exclusão social e em decorrência da publicação do Informe Lalonde, em que o componente estilo de vida passou a ter destaque na formulação de propostas do setor saúde, a visão reducionista centralizada na ação individual da própria saúde passa a ser criticada. Os 
contextos sociais, econômicos e políticos vigentes não podiam ser esquecidos como propiciadores de comportamentos que se formam e se instalam entre as massas.

A saúde é um direito humano fundamental; assim, promoção e proteção da saúde dos povos é essencial para o contínuo desenvolvimento econômico e social. Contribui para a melhor qualidade de vida e para a paz mundial, sendo direito e dever dos povos participarem individual e coletivamente no planejamento e na execução de seus cuidados de saúde.

A conferência de Alma-Ata chama ainda a atenção para que todos os governos cooperem num espírito de comunidade e serviço, assegurando cuidados primários de saúde a todos os povos, uma vez que a consecução da saúde do povo de qualquer país interessa e beneficia diretamente todos os outros países.

A Carta de Otawa (Canadá, 1986), elaborada durante a I Conferência Internacional de Promoção de Saúde, reforçou essa visão e trouxe uma nova definição de promoção da saúde como "o processo de capacitação da comunidade para atuar na melhoria da sua qualidade de vida e saúde, incluindo uma maior participação no controle desse processo".

E acrescentou ainda que, "para atingir um estado de completo bem-estar físico, mental e social, os indivíduos e grupos devem saber identificar aspirações, satisfazer necessidades e modificar favoravelmente o ambiente" (MINISTÉRIO DA SAÚDE, 2001).

As discussões se apoiaram nos progressos alcançados com a Declaração de Alma-Ata para os Cuidados Primários em Saúde, com o documento da OMS sobre Saúde Para Todos e o debate ocorrido na Assembléia Mundial da Saúde sobre as ações intersetoriais necessárias para o setor.

Esse documento considerou como pré-requisitos para a saúde: paz, educação, moradia, alimentação, renda, ecossistema estável, sustentabilidade de recursos, justiça social e eqüidade, estendendo a responsabilidade por essa promoção à ação coordenada de governo, setor saúde, setores sociais e econômicos, organizações não governamentais e organizações voluntárias (MINISTÉRIO DA SAÚDE, 1996). 
O mesmo documento considera a saúde como um conceito positivo, preconizando cinco campos de ação: políticas públicas saudáveis, ambiente favorável, ação comunitária, desenvolvimento de habilidades pessoais e reorientação dos sistemas de saúde.

Essa conferência propõe um comprometimento para atuar no campo das políticas públicas saudáveis e advogar um compromisso político claro em relação à saúde e à eqüidade em todos os setores. Para tal, é necessário agir contra a produção de produtos prejudiciais à saúde, a degradação dos recursos naturais, as condições ambientais e de vida não-saudáveis e a má nutrição, dirigindo sua atenção a novos temas da saúde pública, tais como: poluição, trabalho perigoso, questões da habitação e dos assentamentos rurais. E ainda mais: propõe lutar contra as desigualdades em saúde produzidas pelas regras e práticas desta mesma sociedade, reconhecendo as pessoas como o principal recurso para a saúde.

Passados dois anos da primeira Conferência, a Declaraçãa de Adelaide (Austrália, 1988) vem reforçar o destaque às políticas públicas saudáveis, explicitando a preocupação por um meio ambiente saudável e responsabilizando as ações internacionais no campo da saúde. As políticas públicas em saúde dos países desenvolvidos teriam a obrigação de assegurar um impacto positivo na saúde dos países menos desenvolvidos.

Nesta II Conferência Internacional de Promoção da Saúde destacou-se o apoio à saúde da mulher, alimentação e nutrição, o combate ao tabaco e álcool e a criação de ambientes favoráveis. Assim, mudar os modos de vida, de trabalho e de lazer tem um significativo impacto sobre a saúde. A conservação dos recursos naturais do mundo precisaria ser enfatizada como uma responsabilidade global, devendo fazer parte de qualquer estratégia de promoção da saúde, pois, ao mesmo tempo em que esta é um direito da humanidade, é também um sólido investimento social.

A III Conferência Internacional de Promoção da Saúde aconteceu em Sundsvall (Suécia, 1991), com a participação de 81 países, trazendo a seguinte afirmação: “Ambientes e saúde são inseparáveis e interdependentes”. Prevalece ainda o destaque aos aspectos físico e social do nosso entorno como um espaço no qual 
as pessoas vivem, trabalham, têm acesso ao lazer, aos recursos e oportunidade para ter maior poder de decisão. Essa Conferência aponta para a situação de milhares de pessoas que vivem em extrema pobreza e privação, o que as afasta da meta da Saúde para todos no ano 2000.

O rápido crescimento populacional é a maior ameaça ao desenvolvimento sustentável. As migrações das áreas rurais para o setor urbano aumentam de maneira drástica o número de pessoas que passam a viver em favelas, com os problemas decorrentes de falta de água potável, alimentação adequada, saneamento básico e do acesso inadequado aos cuidados básicos de saúde.

Em meio aos conflitos armados, rápido crescimento populacional, possibilidade do esgotamento de recursos, entre outras manifestações contrárias às metas de saúde, torna-se necessária a ação intersetorial para envolver educação, desenvolvimento urbano, indústria, transporte e agricultura, comprometendo governos e participação popular em interações coordenadas na busca de soluções.

Durante o período de 1992 a 1996, não se realizaram Conferências Internacionais de Promoção da Saúde, mas sim Conferências, eventos e encontros regionais, como a Conferência de Santa Fé de Bogotá, Colômbia, no ano de 1992, resultando na Declaração de Santa Fé de Bogotá - Promoção da saúde e igualdade.

Essa Conferência tratou da promoção da saúde na América Latina como um desafio para transformar relações, conciliar os interesses econômicos e os propósitos sociais de bem-estar para todos, além de trabalhar pela solidariedade e eqüidade social (MINISTÉRIO DA SAÚDE, 2001).

No ano seguinte, aconteceu a IV Conferência Internacional sobre Promoção de Saúde, deixando como documento a Declaração de Jacarta (1997) - Novos Protagonistas para uma Nova Era: Orientando a Promoção da Saúde pelo Século XXI adentro, como um momento crítico das estratégias internacionais de desenvolvimento em prol da saúde. Sendo a primeira a incluir o setor privado no apoio à saúde, propõe reexaminar os determinantes da saúde para identificar estratégias necessárias para enfrentar os desafios do próximo século. 
Durante essa conferência, os congressistas voltaram seu olhar para as tendências demográficas, tais como a urbanização, o aumento no número de pessoas idosas e a prevalência de doenças crônicas. Além disso, um comportamento mais sedentário, resistência a antibióticos e a outros medicamentos disponíveis, maior uso abusivo de drogas e a violência civil e doméstica ameaçavam a saúde e o bem-estar. Assim, é de capital importância que a promoção da saúde evolua para fazer frente aos determinantes da saúde e com especial atenção à pobreza, que é, acima de tudo, a maior ameaça à saúde.

Em 1998, em Genebra, ocorreu a Rede de Megapaíses para a Promoção da Saúde, direcionando esforços para prioridades nacionais, embora tenha destacado a necessidade da aliança entre os países e a OMS.

Até o ano 2000, onze países teriam uma população de 100 milhões ou mais. Juntos, esses megapaíses atingem $60 \%$ da população do mundo: Bangladesh, Brasil, China, Índia, Indonésia, Japão, México, Nigéria, Paquistão, Federação dos Estados Russos e Estados Unidos da América. Essa diversidade de países engloba todos os níveis de desenvolvimento, experienciando diferentes estágios nos atuais padrões de morbidade e de mortalidade (MINISTÉRIO DA SAÚDE, 2001).

Os megapaíses, trabalhando juntos, poderiam se constituir em vozes poderosas na agenda mundial de políticas de promoção da saúde, dando destaque a cinco metas (Ministério da Saúde, 2001 op. cit.):

- melhorar a base de informações concernentes à promoção da saúde, compartilhando políticas de promoção da saúde e programas exitosos, bem como pesquisas e avaliações;

- desenvolver a saúde promovendo estratégias nas áreas: Estilos de vida saudáveis; Curso de vida saudável; Preservação do meio ambiente; Preservação de assentamentos;

- mobilizar os recursos existentes, redistribuídos, bem como recursos diversos de fontes não-tradicionais, visando aumentar a condição da saúde como uma prioridade nacional; 
- aumentar a colaboração intersetorial por meio de agências governamentais e nãogovernamentais, pelos setores públicos e privados, objetivando melhorar a saúde;

- direcionar as questões comuns aos megapaíses, tais como: redistribuição de recursos nas grandes burocracias, construir competências com parceiros nacionais, alcançar grandes populações por meio da mídia - usando tecnologia para prover educação à distância e treinamentos.

Em junho de 2000, aconteceu a V Conferência Internacional sobre Promoção de Saúde no México, contando com a possibilidade de reforçar o mesmo conceito de saúde das declarações anteriores e documentá-lo na Declaração do México. Na ocasião, os Ministros da Saúde reunidos "reconhecem que a consecução do nível de saúde mais alto possível é um elemento positivo para o aproveitamento da vida e necessário para o desenvolvimento social e econômico e a equidade".

A VI Conferência Internacional de Promoção da Saúde ocorreu em Bangkok (Tailândia), em agosto de 2005, abordando como tema central "Políticas e Parcerias para a ação objetivando os determinantes da saúde em um mundo globalizado”.

A referida Conferência posicionou a saúde no centro do desenvolvimento global, nacional e local, complementando e reafirmando os valores, princípios, estratégias de ação sobre promoção da saúde estabelecidas na Carta de Ottawa e outras Conferências anteriores, confirmadas pelos Estados Membros através da Assembléia Mundial de Saúde (WHO, 2008).

A Conferência de Bangkok apontou também para os determinantes da saúde no novo contexto global, estabelecendo alguns fatores críticos que influenciam a saúde e incluem (WHO, op.cit.):

- aumento das desigualdades dentro e entre países;

- novos padrões de consumo, comunicação e comercialização;

- mudanças no meio ambiente global;

- urbanização;

- outras mudanças rápidas e adversas nas áreas social, econômica e demográfica, que atingem condições de trabalho, o ambiente e a cultura das comunidades. 
O momento atual exige um aprofundamento ainda maior das ações em promoção da saúde, já que homens e mulheres são afetados diferentemente e a vulnerabilidade das crianças, marginalizados, portadores de deficiência e indígenas aumentou.

As sequiências de Conferências Mundiais, além da maturidade do conceito de promoção da saúde, têm contribuído para formar uma consciência da responsabilidade em saúde de uns sobre os outros, quer pensando na ação entre países quer pensando em vizinho, ou aquele que compõe seu entorno.

\section{Ações para promoção da saúde no Brasil}

No Brasil, a promoção de saúde vem adquirindo diferentes significados, conforme as concepções defendidas por seus difusores (ROCHA, 2001).

Até a década de 1980, as políticas sociais no Brasil foram classificadas como residuais (por não abrangerem toda a comunidade nacional como objetivo da proteção social) e meritocrático-corporativas (porque a definição dos direitos sociais ficou restrita aos indivíduos que contribuíam para a Previdência Social) (DRAIBE, 1988).

Com um agravamento da crise brasileira a partir da década de 1980, a previdência com problemas de caixa provenientes de uma política que estimulava a corrupção e o desvio de verbas, resultando na incapacidade para dar conta das demandas criadas, e, em contrapartida, o regime-militar autoritário, fez-se necessário buscar alternativas de legitimação diante da insatisfação da população (RONCALLI, 2003).

Por meio de iniciativas tomadas na área da saúde, desde meados dos anos 70, idéias reformadoras foram amadurecendo e acompanhando a distensão política, que se iniciava então. Encontros promovidos por lideranças políticas, sindicais, sanitárias e membros da tecnoburocracia política priorizaram a discussão de uma agenda para a saúde e para a definição dos fundamentos de um sistema público, participativo e universal. Desses encontros, associações foram sendo formadas, como o Centro Brasileiro de Estudos de Saúde (CEBES) e a Associação Brasileira de Pós-graduação em 
Saúde Coletiva (ABRASCO), que tiveram acentuado papel na elaboração teórica e programática das propostas de reforma.

Lutando por políticas mais universalistas, iniciado em pleno regime autoritário da ditadura militar e conduzido por profissionais da saúde e intelectuais da área da saúde coletiva, o movimento pela Reforma Sanitária amplia-se mais ainda com a incorporação de lideranças políticas sindicais e populares e também de parlamentares interessados na causa (RONCALLI, op.cit.).

O termo "Reforma Sanitária" foi usado pela primeira vez no país em função da reforma sanitária italiana. A expressão ficou esquecida por um tempo até ser recuperada nos debates prévios à $8^{\text {a }}$ Conferência Nacional de Saúde, quando foi usada para se referir ao conjunto de idéias que se tinha em relação às mudanças e transformações necessárias na área da saúde.

Essas mudanças não abarcavam apenas o sistema, mas todo o setor saúde, introduzindo uma nova idéia na qual o resultado final era entendido como a melhoria das condições de vida da população. Considerado "o eterno guru da Reforma Sanitária", Sergio Arouca costumava dizer que o movimento da reforma sanitária nasceu dentro da perspectiva da luta contra a ditadura.

A política de saúde edificada no Brasil a partir do esforço da sociedade em seu processo de redemocratização, culminando com a Constituição de 1988, tem em sua estrutura elementos para o desenvolvimento de ações e estratégias de promoção da saúde. Os princípios de universalidade, integralidade e eqüidade e as diretrizes de descentralização e organização hierarquizada podem ser potencializados a partir do olhar e de ações de promoção da saúde, contribuindo para a qualificação do Sistema Único de Saúde e, a partir deste, para a construção de uma ampla aliança nacional tendo como centro a qualidade de vida (MINISTÉRIO DA SAÚDE, 2001).

Uma política de promoção da saúde deve, então, colaborar para o aprofundamento das promessas da reforma sanitária brasileira. Promessas que, além da construção do Sistema Único de Saúde- SUS, instituído em 1990 na regulamentação da Constituição Brasileira de 1988 (através da Lei Orgânica da Saúde), apontam para a modificação das práticas sanitárias com a superação da baixa-cobertura em direção à 
universalização, busca da eqüidade, integralidade do cuidado e respeito à cidadania. Promessas também que se comprometem com a democratização da saúde, da sociedade, do Estado e das Instituições (MINISTÉRIO DA SAÚDE, op cit).

No entanto, segundo WESTPHAL (2008), promoção da saúde não é, apenas, um conjunto de procedimentos que informam e capacitam indivíduos e organizações ou que buscam controlar determinantes das condições de saúde de grupos populacionais específicos. Promover saúde é uma imposição das circunstâncias atuais que apontam para a necessidade imperiosa de novos caminhos éticos para a sociedade.

A autora destaca ainda: o conceito de promoção da saúde que reforça a importância da ação política, as condições e as mudanças nos estilos de vida, tornou-se referência para o movimento da "nova saúde pública" (WESTPHAL in ROCHA et al. 2008).

E, ainda mais, segundo VALADÃO (2004),

... a nova promoção da saúde, assim como a concepção de cidadania do texto constitucional, embora sejam produtos de trajetórias específicas, afirmam-se como discurso contra-hegemônico, no contexto de agravamento das iniqüidades decorrente do modelo global de desenvolvimento econômico (p.20).

De qualquer forma, em concordância com MINAYO (2000a, p. 16), é necessário aprofundar o conceito e as ações de promoção da saúde para que: “... mais do que uma idéia de senso comum, programa ideológico ou imagem-objetivo, possa nortear o sentido verdadeiramente positivo de qualidade de vida".

Preparar cada indivíduo para assumir o controle e a responsabilidade sobre a sua própria saúde e sobre a saúde da comunidade, para a participação, para a tomada de decisões, para o controle social, para exigir direitos, para atuar sobre os fatores determinantes e condicionantes da sua saúde é trabalhar a promoção da saúde. (Pelicioni MCF, Pelicioni AF e Toledo, 2007). 
Esse sentido poderá não só deslocar o foco da acentuada medicalização e prevenção da saúde, como também elevar a importância da escola como instrumentalizadora da melhoria da qualidade de vida.

\subsection{Escolas promotoras da saúde}

A Unesco e a Organização Mundial de Saúde vêm trabalhando com questões de saúde escolar desde a década de 60.

Naquela época, as duas organizações publicaram um manual de referência denominado Planning for Health Education in Schools, baseado em fontes de diversos países (VYNCKT, 1992/3). Tratava-se de um texto pragmático, contendo indicações para planejamento e a implementação de programas nacionais de saúde escolar, com base em consultas a especialistas e governos.

A autora citada avalia que, caso o processo de preparação desse livro tivesse incluído pesquisa de campo sobre as condições precárias de vida das crianças em idade escolar, ele teria uma natureza diferente e expressaria outra visão de educação em saúde. Embora essa publicação guarde em si uma valorosa contribuição, a observação de VYNCKT (op.cit.) é relevante, pois aponta que a proposição não considerava a realidade dos sujeitos para os quais era destinada.

A partir da década de 1980, a afirmação do conceito e do movimento de promoção da saúde leva, também no campo da saúde na escola, à proposição de abordagens que buscam ser mais abrangentes. Denominadas Comprehensive school health, as iniciativas tomadas nos Estados Unidos da América, a partir de 1989, foram acompanhadas de debates e publicações apoiadas pela OMS (WHO, 1991, 1992).

A formulação denominada "Escola Promotora de Saúde" ganha corpo na Europa, em 1991, com o lançamento de um projeto piloto desenvolvido pelo escritório regional da OMS. E Promoção da Saúde na escola mostra-se como o conjunto de estratégias que têm por objetivo produzir repercussões positivas sobre a qualidade de vida e os determinantes da saúde dos membros da comunidade escolar. 
Entendida como cenário fundamental (key setting) para a promoção da saúde, a escola ganha espaço destacado na agenda dos organismos internacionais na década de 1990. Diversos projetos de âmbito internacional são instituídos para implantar atividades nessa direção, entre eles a Rede Européia de Escolas Promotoras de Saúde (WHO, 1996a), a Iniciativa Global de Saúde Escolar (WHO, 1996a) e a Rede Latina Americana de Escolas Promotoras de Saúde (OPS, 1996). Guias e modelos para a ação são preparados, tendo como foco principal os países em desenvolvimento, desenhados com vistas a incentivar e instrumentalizar os sistemas nacionais de educação na elaboração de políticas e programas voltados para a saúde na escola (OPS/OMS, 1996; OPS, 1998; WHO, 1991, 1992, 1996b, 1996c, 1996 d).

No ano 2000, é elaborada e divulgada a proposta FRESH - Focusing Resources

on Effective school Health (WHO/UNESCO/UNICEF/WORD BANK, 2000), que sintetiza a defesa conjunta da instituição de políticas nacionais de promoção de saúde na escola por seus organismos signatários.

\section{Ações em âmbito nacional}

No Brasil, a pesquisa das transformações ocorridas ao longo da história mostra que a saúde escolar acompanhou de perto as tendências internacionais (VALADÃO, 2004). Originariamente marcada pelo movimento higienista e denominada higiene escolar, propunha abordagem do asseio e higiene dos escolares para evitar o contágio de doenças transmissíveis (OLIVEIRA, 1991).

Ao pesquisar as contribuições da educação em saúde para a promoção da saúde escolar, BARTLETT (1981) concluiu que programas focalizados em temas variados, como drogas, álcool, tabaco, nutrição ou trânsito, são muito eficientes em aumentar conhecimentos, têm alguma eficiência em alterar atitudes, porém, com raras exceções, são ineficazes na mudança das práticas relacionadas à saúde.

Portanto, a busca por novas estratégias de ação dentro de um espaço que mantém mais de $80 \%$ dos jovens, com permanência expressiva durante uma fase da vida e fundamental na formação da personalidade, não pode ser esquecida. 
Posterior a esse estudo, SILVA (2002) realizou uma pesquisa junto aos professores da rede estadual de São Paulo e concluiu que a maioria deles ainda não conhecia o conceito da Escola Promotora de Saúde.

Mesmo sendo discutível a efetividade de programas de promoção da saúde e de causar polêmica, por exemplo, quanto às questões voltadas à Saúde Sexual como educação, já que revela um campo de força de nossos desejos e não apenas expressões de um comportamento social, não podemos caminhar em descompasso com um novo paradigma mundial de atenção à saúde.

De fato, não é possível que a escola dê conta de prevenir doenças genéticas, como as manifestações de Deficiências Físicas Múltiplas ou agravos de saúde de origem biológica, mas pode promover a inclusão e permitir uma melhoria da qualidade de vida para aqueles que nela buscam ter uma participação na sociedade.

Segundo VALADÃO (2004), embora permaneça no Ministério da Educação o Programa de Saúde do Escolar, a saúde na escola brasileira contempla uma mescla de antigas e novas idéias e práticas: “... portanto, é um cenário no qual os princípios, leis, conceitos e práticas que têm relação direta com a promoção da saúde no âmbito da escola se perpassam, conflitam, superpõem, mas raramente se comunicam ou articulam..." (p.35).

Essa situação causa pesar, já que as contribuições da escola em relação à saúde humana podem ser essenciais e múltiplas, não só pelo conhecimento através das disciplinas voltadas à saúde como também por se constituírem em rico cenário para a formação da personalidade. Além disso, permite reflexões sobre os determinantes da saúde destacados nas Conferências Internacionais.

Na década atual, o Compromisso Todos pela Educação adotado pelo governo federal deu impulso a uma ampla mobilização social e a uma aclamada busca de "Uma educação básica de qualidade para todos os Estados Brasileiro em 2021”, bicentenário da Independência do Brasil.

Prioridade do Plano de Desenvolvimento da Educação (PDE) lançado em abril de 2007, a atenção à saúde do escolar permeia e compõe o cenário das intenções preconizadas pelo referido plano. 
Em 2008, os Ministérios da Educação (MEC) e da Saúde definiram os eixos do programa Saúde na Escola, que integra os projetos do Plano de Desenvolvimento da Educação (PDE): avaliação das condições de saúde do estudante; promoção da saúde e prevenção; monitoramento e avaliação da saúde; capacitação dos profissionais da educação, da saúde e de jovens; monitoramento e avaliação das atividades do programa.

Um grupo de trabalho criado pelo MEC e Ministério da Saúde definiu diretrizes para o atendimento básico de saúde na escola. As ações elaboradas buscam integrar as instituições da educação básica e as unidades básicas de saúde com equipes da Saúde da Família. O objetivo é articular prática de educação e saúde para promover a vida saudável de estudantes.

Neste momento, resta sabermos se mais uma vez todas essas indicações de atuação intersetorial não estarão tomando corpo apenas em papéis ou ainda se volatizando numa falta de estrutura operacional. Além disso, o objetivo de articular práticas para promover vida saudável necessitaria estar apoiado no conceito positivo de promoção da saúde e não associado, apenas, à prevenção de doenças.

Estados brasileiros, como Paraná e Rio de Janeiro, com olhares voltados ao PDE têm se preocupado com uma melhoria do desempenho de suas escolas. Com a preparação de material de apoio específico, buscam conquistar melhores índices de aprendizado de seus alunos.

O PDE paranaense, por exemplo, é um programa idealizado em 2007 e desenvolvido pela Secretaria de Estado da Educação (Seed), em parceria com a Secretaria de Estado da Ciência, Tecnologia e Ensino Superior (Seti) e com Universidade Estadual e Federal, que possibilita o afastamento dos professores de suas atividades por dois anos para atualização de seus conhecimentos. No primeiro ano do curso, o professor fica afastado em $100 \%$ das atividades e no segundo, em $25 \%$. (SEED, 2008)

O programa prevê o ingresso anual de 1.200 novos professores, selecionados por meio de concurso e aberto aos professores efetivos. Durante o curso, sob a orientação de um docente titular das universidades conveniadas, o professor participa de atividades 
junto às instituições de Ensino Superior e grupos de professores das escolas da rede pública, produzindo conhecimentos teórico-práticos para a melhoria do ensino.

Em São Paulo, as ações encaminhadas pela Secretaria Estadual de Educação vinculada ao PDE se expressam através do Programa de Qualidade das Escolas (PQE) com a implementação, em 2008, do "São Paulo faz escola" (SEE-SP; 2008a).

Essa iniciativa implementou uma nova Proposta Curricular, enfatizando, inicialmente, a alfabetização e recuperação de conteúdos básicos do aluno encaminhadas por meio do "Jornal do Aluno". Para o professor, propôs os conteúdos programáticos de suas aulas por meio de Revistas e cadernos disponibilizados às unidades escolares a cada bimestre e com tutoria on-line.

Porém, o descompasso, no envio das revistas do professor, no sucesso da assimilação dos conteúdos pelo educando e na falta de recurso para produzir o material do aluno, que, muitas vezes, necessitava ser reproduzido pelas próprias escolas, se constituiu mais uma vez em atropelos no dia-a-dia do ambiente escolar. Esse cenário propiciou manifestações de críticas à proposta que certamente foram registradas on-line em rede aberta pela Secretaria de Educação. Novamente, se repetem as dificuldades no encaminhamento das ações do setor público durante suas tentativas de implementação de novas propostas.

A Secretaria Estadual de Educação paulista instituiu ainda, na mesma ocasião, o IDESP (Índice de Desenvolvimento da Educação do Estado de São Paulo), um indicador de qualidade das séries iniciais $\left(1^{\mathrm{a}}\right.$ a $4^{\mathrm{a}}$ séries $)$ e finais $\left(5^{\mathrm{a}}\right.$ a $8^{\mathrm{a}}$ séries $)$ do Ensino Fundamental e do Ensino Médio.

$\mathrm{Na}$ avaliação de qualidade das escolas feita pelo IDESP foram considerados dois critérios complementares: o desempenho dos alunos nos exames do Sistema de Avaliação de Rendimento Escolar de São Paulo (SARESP) e o fluxo escolar. O IDESP tem o papel de dialogar com a escola, fornecendo um diagnóstico de sua qualidade, apontando os pontos em que precisa melhorar e sinalizando sua evolução ano a ano.

Esse índice pretendeu possibilitar a criação de metas para cada escola, para permitir um redirecionamento de suas ações. As metas por escola se constituem num instrumento de melhoria da qualidade do ensino, sendo estabelecidas a partir de critérios 
objetivos e transparentes. Segundo a atual Secretária de Educação Maria Helena Guimarães de Castro, em pronunciamento on-line pela própria homepage da secretaria em março de 2008, estas metas servem como um guia para que os professores, gestores escolares, pais de alunos e a comunidade acompanhem a evolução das escolas no aprimoramento da qualidade de ensino.

A proposta estadual de São Paulo, oferecida a Diretores e Professores Coordenadores das escolas, também abordou a Saúde Pública por meio de videoconferências intituladas "Temas da Atualidade". Destacando a importância de ações que incrementem a disponibilização de recursos públicos e, conseqüentemente, possibilitem enfrentar as doenças causadas pela carência dos mesmos, buscou despertar seus gestores para um trabalho voltado à saúde.

Ainda voltado as ações de aprimoramento e formação contínua do corpo docente, o governo do estado instituiu pelo Decreto $n^{\circ} 48.298$, de três de dezembro de 2003 o Projeto Bolsa Mestrado que tem em seu Artigo 2o - "A Bolsa Mestrado destina-se, exclusivamente, ao titular de cargo efetivo do Quadro do Magistério da Secretaria da Educação, integrante de classe de docentes ou de suporte pedagógico, admitido em curso de pós-graduação ministrado por instituição de ensino de nível superior, da rede pública ou privada...”(SEE-SP 2008b)

De fato, o compromisso das escolas com a melhoria do aprendizado de seus alunos deve ser concretizado, também porque nossa Lei Magna, que se refere à educação, deve ser respeitada. Porém, não poderíamos deixar de referenciar a importância de se voltar aos pressupostos da Promoção da Saúde.

Abordar o tema de forma tradicional, sem oferecer a instrumentalização aos professores e gestores para que adquiram condições de agir de forma emancipatória e realmente entender seu papel na promoção da saúde, é continuar tornando-os meros executores de propostas apoiadas em momentos políticos.

É oportuno ressaltar ainda que, concordando com VALADÃO (2004), a promoção da saúde na escola poderá contribuir na busca de alternativa emancipatória, quando sair dos limites das ciências da saúde para legitimar-se como prática dialógica, 
aceitando a participação entre os membros da comunidade, sendo que, nesse contexto, o professor é peça fundamental.

A emancipação aqui referida requer consciência crítica, a decisão democrática, implicando em envolvimento responsável e compartilhado, a transformação que está relacionada às alterações geradas coletivamente, e a crítica educativa, que diz respeito à proposta oferecida por participantes do processo (SAUL, 1994).

Ao estabelecer bases de uma pedagogia a partir de sua convivência com a promoção da saúde, o educador poderá eliminar as raízes das relações autoritárias, buscando um modelo em que não há escola nem professor, mas, sim, círculos de diálogo comprometidos com um ambiente propício à aprendizagem e bem-estar de todos enfatizando a participação do aluno e reconhecendo a troca de experiência entre professor e aluno em uma abordagem crítica e construtiva.

\subsection{O papel do professor}

Foco do olhar de inúmeros pesquisadores e nas mais variadas áreas do conhecimento, o professor recebe destaque pelo seu real valor. Peça fundamental nas escolas pode orientar o aluno a uma teia de significados do conhecimento e promover a aprendizagem não só acadêmica, como também na construção da sua identidade, do seu caminho pessoal e profissional - do seu projeto de vida.

Para VYGOTSKY (1977)

[A aprendizagem] não é em si mesma desenvolvimento, mas uma correta organização da aprendizagem da criança, conduz ao desenvolvimento mental, ativa todo um grupo de processos de desenvolvimento, e esta ativação não poderia produzir-se sem a aprendizagem ( p. 47).

Ao mesmo tempo, educar na escola é colaborar para que professores e alunos transformem suas vidas em processos permanentes de aprendizagem, garantindo assim o 
desenvolvimento de habilidades que lhes permitam encontrar seus espaços pessoais, sociais e produtivos.

Nos dias de hoje, para se aproximar do aluno, o professor tem um grande "leque" de opções metodológicas, de possibilidades de organizar sua comunicação, de introduzir um tema, de trabalhar com os alunos de forma presencial e virtualmente.

Segundo ANASTASIOU e ALVES (2004),

...a formulação do conhecimento torna-se uma ocasião de alargamento ativo do aprendizado do aluno, de sua prática, que pode ser predominantemente perceptiva, motora ou reflexiva. Isso poderá ser organizado mediante ações tais como estudo de textos, vídeos, pesquisas, estudo individual, debates, grupos de trabalhos, seminários e práticas nas quais se exercitam as relações que possibilitam identificar, pela avaliação, como se elabora o objeto de conhecimento. Daí, então, a necessidade da escolha de estratégias com várias e expressivas práticas sugeridas ao aluno, objetivando ultrapassar seus dados iniciais sobre o objeto do conhecimento (p.31).

De acordo com GOMES e col. (2006), a prática docente envolve múltiplas ações do professor, não só na condução dos grupos como também na gestão de suas classes, na preparação dos conteúdos, na aproximação das disciplinas com o projeto pedagógico e o currículo, constituindo-se assim um saber próprio da docência. Para isso, é necessário manter-se atualizado, aprendendo e reaprendendo a ser, a conviver, alicerçado em novos valores e princípios.

As áreas de competência, tais como: organizar, gerir e animar situações de aprendizagem; envolver os alunos em sua aprendizagem; enfrentar deveres e dilemas da profissão são, segundo PERRENOUD (1996), pressupostos referenciais do cotidiano desse profissional que, muitas vezes, desempenha heroicamente sua função.

Porém, a eficácia pedagógica muitas vezes é resultado da cooperação dos alunos e de suas famílias. Certamente, a competência profissional consiste, em parte, em criar, manter e desenvolver essa cooperação, mas isso não garante aos alunos vontade de 
aprender, de estudar ou simplesmente de ir à escola; é preciso agir sobre valores e atitudes, o que não é fácil.

Romper inúmeros tipos de resistência a que nossos alunos estão sujeitos, associado à sedução da estrutura sociedade atual, tem sido tarefa de responsabilidade do professor. No entanto, não se pode julgar o professor contabilizando os resultados de sua ação sem considerar seus "adversários" na relação educativa. A cooperação e a resistência que encontramos numa sala de aula dependem de um grande número de fatores que podem remeter, muitas vezes, a uma incompetência coletiva mais que a uma incompetência individual.

É certo que a atuação docente está ligada a aspectos que ultrapassam o domínio dos conteúdos. Pertencer a uma etnia, a uma classe social, a um sexo, a uma faixa etária, e ainda a história do professor e sua cultura, de fato, exercem uma influência sobre a comunicação e a relação pedagógica.

Sendo assim, a profissionalização pode ser uma resposta à complexidade das situações e das relações educativas e às expectativas crescentes das sociedades em relação ao sistema educativo.

Enfrentar a complexidade é, segundo SCHON (1983) se aproximar da prática com reflexão. A capacidade de cooperação com os colegas, utilizando conhecimentos múltiplos, instrumentos metodológicos e, principalmente, um saber-analisar bem experiente pode guiar observações, interpretações e novas ações que reconduzem o trabalho docente.

Segundo SERRÃO (2005),

...a prática exige determinados comportamentos do professor como, por exemplo: surpreender-se com o aluno; buscar as razões dessa surpresa para poder compreendê-la, formulando problemas e hipóteses de resolução que serão possíveis de serem verificadas. Esse processo é denominado pelo autor [Donald A. Schön] como o momento da reflexão na ação que deve ser seguido pela reflexão sobre a reflexão na ação, que por sua vez proporciona ao professor reconstituir o trajeto percorrido desde a surpresa até a solução do problema originalmente advindo da ação docente... (p. 152). 
Nesse sentido, AQUINO (in SAYÃO e AQUINO, 2004) adverte que nunca se é professor por completo. O autor defende a idéia de que há um espaço aberto e em constante mutação no ofício docente. Com isto, sempre podemos pensar em novas propostas pedagógicas para atender nosso alunado, já que seria pressuposto na profissão docente jamais se esgotar.

Já há muito tempo a criatividade do professor também vem sendo apontada como recurso para lidar com o processo, mas falta a ele tempo para inventar novidades todos os dias. ALMEIDA (2001) ressalta: "existem procedimentos criativos e pertinazes marcando nossos produtos e práticas educativas que são absolutamente inovadores, frutos de imaginação sensível e muita dedicação de indivíduos e grupos organizados”. O autor destaca ainda: "se uma rede inteira de educadores toma consciência de seus processos de identidades pedagógicas, cognitivas e epistemológicas teremos um mapeamento de como é produzir saber sobre o ato de pensar, de aprender e de construir conhecimento" (p. 94).

A sensibilidade do professor criativo geralmente vem acompanhada da consciência da difícil caminhada, já que na subjetividade das relações escolares se insere a responsabilidade de poder auxiliar o aluno em suas superações. Afinal, "quanto mais solidariedade exista entre o educador e educando no trato deste espaço, tanto mais possibilidades de aprendizagem democrática se abrem na escola" (FREIRE, 1996, p.97).

O diferencial da presença do professor pode ser comprovado mais uma vez por CHIARO E LEITÃO (2005), que, ao trabalharem com dois grupos de alunos, sendo um deles com a mediação do professor durante um debate sobre conteúdos de História, concluíram o seguinte:

...embora a argumentação em ambos os grupos possibilite reflexão, discussão e construção de novos sentidos, o processo de apropriação do conteúdo curricular depende significativamente da mediação do professor na medida em que suas ações discursivas conferem estatuto epistêmico ao discurso dos alunos (p.356). 
O grupo que não contou com o apoio do professor, embora com participação ativa, não pôde recriar, através de suas atividades e experiências, um conhecimento culturalmente produzido, tornando o professor, assim, fundamental representante do saber convencional a ser aprendido pelos alunos.

Com todo seu valor, não nos parece exagero fazer uso das palavras de POUGY (2007) e considerar que o papel do professor é

...o de alguém atento, preparado, ensaiado, um ser que inspira seus alunos por ser um verdadeiro apaixonado pelo saber nômade. O devir mestre deseja um agenciamento que propicie a interação no espaço da sala de aula e construa seu próprio método, o que o fará produzir, em conjunto com seus alunos e com os signos presentes no processo de ensino e de aprendizado, verdadeiras obras de arte pedagógica (p.9).

\subsection{Tabagismo e promoção de saúde escolar}

A escola desponta como cenário propício ao debate sobre o tabagismo, também porque convive com jovens que se iniciam mais cedo no consumo de cigarros e outras drogas que os afastam da qualidade de vida tão ressaltada na promoção da saúde.

Como já foi apontada, a maioria dos tabagistas começa a fumar na adolescência, sendo que, se o indivíduo for mantido longe do cigarro nessa idade, dificilmente se tornará um fumante. Segundo dados da pesquisa Perfil do Usuário de Tratamento do Tabagismo, realizada em 2006 pelo Centro de Referência de Álcool, Tabaco e Outras Drogas -CRATOD - São Paulo, 36,54\% dos fumantes começaram com o hábito aos 12 - 14 anos de idade e 28,85\%, aos 15 - 20 anos (LAGO, 2006).

O fumo também tem sido descrito como a "droga de entrada" (gateway drug), já que, segundo pesquisas, a maioria dos jovens que usam drogas pesadas, como maconha, cocaína ou heroína, teve experiência prévia com o tabagismo (Silva apud MS/OPAS, 2004, p.37).

No entanto, a preocupação em abordar o tema não deve estar apoiada apenas em verbosidade. É certo que precisamos da teoria, do conhecimento científico, também 
porque são eles que nos oferecem a base para estabelecer nossos objetivos. Mas, muito mais do que isso, precisamos estar inseridos na realidade social, num contato analítico com o ambiente escolar para levar a teoria para além da comunicação, complementandoa com mudanças de atitude.

Criar a disposição para eliminar antigos hábitos desfavoráveis à promoção da saúde e contribuir para o controle do tabagismo é adotar um agir educativo, comprometido com a reflexão sobre o que poderia dar cor e tom à convivência do alunado com o mundo ao seu redor.

GORDON e TURNER (2003) pesquisaram duas escolas americanas de ensino fundamental, nas quais havia uma diferença significativa na taxa de alunos fumantes, procurando identificar outras diferenças que pudessem estar associadas a esse fato ou que permitissem explicá-lo. Os autores revelaram que a escola cujos alunos apresentavam baixo tabagismo pautava o trabalho educativo em valores holísticos, operava de acordo com uma filosofia centrada na criança e em seus interesses, oferecendo um programa diferenciado para suporte às suas necessidades. Em contraste, as escolas com alta taxa de fumantes mantinham o foco de seu trabalho nos resultados educacionais.

Entendido aqui o conceito de promoção da saúde, este último relato vem ao encontro da proposta da Escola Promotora da Saúde, que tem como princípio de trabalho não apenas debater os focos de doenças, mas também oferecer condições de reflexão sobre os determinantes da saúde.

A relação entre atividade física e outros comportamentos relacionados à saúde em 11.631 adolescentes americanos, em dados coletados durante 1990 no Projeto Youth Risk Behavior Survey, também mostrou que o baixo coeficiente de atividade física estava associado ao uso de tabaco e maconha (PATE et al., 1996).

Portanto, a nosso ver, quando desvinculada da realidade, reduzida apenas aos meios de aprendizagem meramente conteudistas, a escola acaba por não desenvolver recursos, condições para acompanhar seus alunos diante da precariedade das relações familiares e do contexto social. 
É nesse aspecto que a promoção da saúde deve ser aprofundada. Segundo LEFÈVRE e LEFÈVRE (2004, p.34), "para compreender a promoção da saúde como transformação de paradigma é preciso também enfrentar um discurso que admita distinguir Promoção da Saúde de Prevenção da Doença, já que a prevenção está ainda integrada ao antigo paradigma",

No Brasil, com o propósito de informar e permitir que as crianças desenvolvam habilidades e competências no controle dos fatores de risco de câncer, o INCA desenvolveu o Programa Nacional de Controle do Tabagismo e Outros Fatores de Risco de Câncer nas Escolas - Programa Saber Saúde, com implementação nacional no início em 1998. Para manter sua abrangência, capacita representantes das Secretarias Estaduais de Saúde e Educação que habilitam os profissionais das Secretarias Municipais, os quais, por sua vez, capacitam os professores de cada escola em diferentes regiões brasileiras. As informações e atividades relacionadas ao consumo do tabaco e outros fatores de risco de câncer são aplicadas ao cotidiano da escola, de forma pulverizada sobre os temas transversais e em várias disciplinas do núcleo comum, e pretende-se agregar ao projeto pedagógico contando com o apoio de livros, guia metodológico, revistas para crianças e adolescentes, adesivos, cartazes e vídeos.

O Programa prioriza os alunos do Ensino Fundamental (6-14 anos) e aproxima alunos do Ensino Médio (15-18 anos) ao processo como multiplicadores, recebendo para isso uma capacitação especial utilizando o mesmo material.

O mesmo programa contempla uma proposta de Ambiente Escolar Livre do Tabaco, procurando estimular mudança de comportamento frente ao tabagismo por professores, alunos e toda a comunidade escolar, estabelecendo ações organizadoras e normativas (INCA/CONPREV, 2001).

No intuito de acompanhar as ações de controle do tabagismo, a OMS, em cooperação com o Centro de Prevenção e Controle de Doenças dos Estados Unidos (CDC), programou em 1999 um Global Tobacco Surveillance System (GTSS) em todos os continentes e na região das Américas, através da Organização Pan-Americana da 
Saúde. O sistema reúne três grandes inquéritos que têm como população-alvo estudantes e profissionais que atuam em escolas e universidades.

Um desses inquéritos é o "Global Youth Tobacco Survey" (GYTS), que, no Brasil, é conhecido como VIGESCOLA. Seu objetivo é monitorar, por meio de pesquisas repetidas e periódicas, comportamentos, hábitos, atitudes e conhecimentos relacionados ao uso do tabaco, entre os escolares de $7^{\mathrm{a}}$ e $8^{\mathrm{a}}$ séries do Ensino Fundamental e $1^{\mathrm{a}}$ série do Ensino Médio. O VIGESCOLA, conduzido no Brasil desde 2002 com a contrapartida dos governos federal, estadual e municipal, tem seus dados publicados para as capitais de dezesseis estados brasileiros; assim, na região norte, Boa Vista, Belém e Palmas; na região nordeste, Aracaju, Fortaleza, João Pessoa, Natal Salvador e São Luís; na região centro-oeste, Campo Grande e Goiânia; na região Sudeste, Rio de Janeiro, Vitória e Cataguases e na região sul, Curitiba, Florianópolis e Porto Alegre (Hallal, 2008).

Com questionário padronizado, definido pelo Programa Mundial, além de questões que dizem respeito a aspectos locais, seu instrumento de coleta inclui informações sobre a prevalência do uso de cigarros e outras formas do tabaco, percepções e atitudes sobre o tabaco, acesso e disponibilidade aos produtos, exposição e fumo passivo, currículo escolar, mídia e propaganda e cessação ao fumo (INCA, 2008).

Porém, apenas cumprindo agenda normativa e informacional, embora intersetorial, essas ações não se colocam em total acordo com as propostas de promoção da saúde, também porque esta deve ser sustentada por uma reação "positiva" ao costume "negativo" de conceber a saúde.

Promover vai muito além de prevenir, e a visão "positiva" apontaria para uma percepção ampliada, integrada, complexa, além de intersetorial, relacionando saúde a meio ambiente, ao modo de produção, ao estilo de vida (LEFÈVRE e LEFÈVRE, 2004, p.27).

Promoção da saúde é a ciência e arte de auxiliar as pessoas a modificar seus estilos de vida em direção a uma condição de saúde mais favorável; ou seja, a um equilíbrio entre saúde física, emocional, social, espiritual e intelectual. As mudanças no estilo de vida podem ser estimuladas pela combinação de esforços para aprimorar a 
percepção, mudar comportamentos e criar ambientes que propiciem boas práticas de saúde (O’ DONNEL, 1989).

Recentemente, estilo de vida foi substituído pelo conceito de qualidade de vida que, segundo MINAYO (2000) refletem conhecimentos, experiências e valores reportados a várias épocas, espaços e histórias diferentes.

Nessa perspectiva, abarcando um programa apenas informativo, sem considerar os fatores relativos à baixa qualidade de vida do seu alunado, a escola estaria trabalhando na superfície de questões e problemas sociais e, portanto, sem se inserir em um contexto e época política particular.

No entanto, longe de propor a interrupção dessas iniciativas, destacamos aqui que elas podem ser complementadas, contando com equipes mais preparadas e inseridas nas necessidades peculiares do seu ambiente de atuação.

Já descrita neste trabalho, a nova proposta curricular da rede estadual de ensino de São Paulo - "São Paulo faz escola" -, também inseriu o tema tabagismo como momento de aprendizado. Porém, é oportuno reforçar que, se sua abordagem for apenas por meio de "verbalizações", não se aproximará da prática docente reflexiva e, conseqüentemente, pouco contribuirá para melhorar o ambiente escolar e reduzir o tabagismo. (SEE-SP, 2008)

O pensar crítico e reflexivo envolve não apenas a dialética, mas também a comunhão com seus pares e o reconhecimento do seu contexto. Quanto melhor fizer essa operação, tanto mais ganhará comunicabilidade em torno da superação das condições desfavoráveis que levam ao uso de "válvulas de escape", como o tabagismo e outras drogas.

A importância da mobilização da sociedade atuando em vários setores do controle do tabagismo também deve ser enfatizada. Órgãos como a Aliança para o Controle do Tabagismo (ACT), composta por organizações da sociedade civil, associações médicas, comunidades científicas, ativistas e pessoas interessadas em coibir a expansão da epidemia tabagista, podem ganhar credibilidade, garantir parceria e contribuir positivamente, revertendo os números alarmantes de jovens que se iniciam no tabagismo. 
Recentemente, em parceria com a Faculdade de Direito da Pontifícia Universidade Católica de São Paulo, a ACT realizou em 2007 um seminário nesta instituição com o título: "Estratégias da indústria do tabaco: Uma história de manipulações", para celebrar um convênio de cooperação cultural com a universidade. Envolvendo estudantes de diversas áreas em controle do tabagismo e com o objetivo de incentivar os alunos a proporem projetos de iniciação científica sobre o tema, a ACT acredita que o número de advogados nessas áreas tende a aumentar conforme aumente o debate sobre o assunto e a pressão da sociedade civil.

É reunindo esforços e buscando envolver os jovens nas diferentes fases de sua vida que ampliamos nossas ações de promoção de saúde e combate ao tabagismo.

O momento atual, enfatizado pela ratificação ao tratado internacional de controle ao tabagismo, torna-se estimulante para desvelar a visão do professor e a reflexão da sua prática como agente participante dessas ações. É necessário produzir conhecimento para fundamentar políticas, programas e intervenções visando à melhoria da situação e do cuidado à saúde, não somente para aqueles que não se iniciaram no hábito de fumar como também para os que podem mudar suas preferências e alcançar uma qualidade de vida.

\subsection{Representação social e tabagismo}

Em sua grande maioria, as pesquisas qualitativas permitem que se reúna o pensamento de grupos sociais quando são colhidos depoimentos ou quando é analisado material documental.

As mudanças dos paradigmas de formas de viver, por sua vez, são alcançadas com uma investigação, em profundidade, dos pensamentos que permeiam os grupos sociais. Portanto, ao optarmos por utilizar a abordagem qualitativa de pesquisa, a qual trabalha com o universo de significados, aspirações, crenças, atitudes e com o saber do senso comum, nos propomos a compreender a formação do pensamento social. 
Para MOSCOVICI (in GUARESCHI, JOVCHELOVITCH e col., 1995), além de um sistema econômico e político, a sociedade é um sistema de pensamento.

Nos universos consensuais estão as práticas iterativas do dia-a-dia, produtoras das representações sociais; isto é, conhecimentos formados espontaneamente dentro de grupos, fundados na tradição e no consenso, dentro de uma lógica e metodologia diferentes.

Segundo JODELET (in GUARESCHI, JOVCHELOVITCH e col., 1995, p. 202), Representação Social é "uma forma de conhecimento, socialmente elaborado e partilhado, tendo uma visão prática e concorrendo para a construção de uma realidade comum a um grupo social".

Como ressalta MINAYO (2000), as categorias de pensamentos, de ações e de sentimentos que expressam a realidade explicam-na, justificando-a ou questionando-a. Com isso, a identificação dessas representações pode proporcionar um ganho qualitativo na atenção a grupos populacionais e possibilitar a visualização de uma faceta da realidade que, habitualmente, não é considerada nos modelos de planejamento ou de educação em saúde.

É oportuno destacarmos que as representações colhidas traduzem os contextos nos quais emergem as comunicações que circulam em um grupo, em uma época e sociedade particulares. Portanto, suas opiniões retratam, muitas vezes, problemas surgidos em núcleos que, apoiados no senso comum, encaminham à sua maneira as formas de fazer as coisas.

A tentativa de captar o pensamento do grupo de professores desta pesquisa com depoimentos a questões abertas, embora não seja fácil, tem a intenção de reduzir as deformações que poderiam estar presentes nas respostas a questionários quantitativos fechados.

Segundo LEFÈVRE (2003), na qualidade de expressão de subjetividade humana, os pensamentos precisam passar previamente pela consciência. Sendo assim, uma forma de permitir essa expressão da consciência pressupõe que o entrevistado elabore suas respostas fundamentando-se em questões que respeitem suas divagações de forma espontânea. 
Para SIMIONI (1996), as abordagens de corte qualitativo permitem a compreensão dos campos na medida em que remetem a uma teia de significados de difícil recuperação através de estudos de corte quantitativo.

POSSATO e col. (2007), por exemplo, analisando os discursos construídos a partir das falas das gestantes tabagistas que mantiveram o hábito de fumar durante toda a gestação, observaram que a vontade de deixar de fumar é predominante. Nessa abordagem qualitativa, através do Discurso do Sujeito Coletivo (LEFÈVRE, 2000), essas mulheres mostraram dificuldades na cessação, mesmo considerando os efeitos do tabagismo. No entanto, os discursos forneceram clara representação negativa do cigarro na gestação, tornando essencial o trabalho no período pré-natal com vistas à interrupção desse hábito.

Para esses pesquisadores, caberá ao profissional de saúde, portanto, apoiar as grávidas para que alcancem êxito no processo de cessação, devendo-se levar em conta a perspectiva das próprias gestantes, com o intuito de romper com as representações cristalizadas e limitantes, em que o problema é posto de forma intransponível.

Outro trabalho, decorrente da nossa dissertação de mestrado, a partir de depoimentos de mães que tornam seus filhos fumantes passivos (ELMÔR, 2005), trouxe a reflexão sobre a importância de projetos educativos e permanentes nas escolas, não obstante todas as ações políticas e sociais voltadas ao combate e prevenção do fumo nos mais diferentes níveis de comunicação da sociedade.

Os depoimentos colhidos de 15 mães fumantes com filhos na faixa etária de 11 a 14 anos permitiram identificar suas idéias centrais quanto ao ato de fumar. Os resultados nos mostraram que a dependência ao vício as impede, mesmo diante do conhecimento dos prejuízos ou da preocupação com os filhos, de parar de fumar.

Ao mesmo tempo em que algumas delas destacaram a angústia do mau exemplo frente ao filho e a preocupação com a possibilidade do tabagismo ser "a porta de entrada para as drogas" o conceito de fumante passivo, destacado por apenas uma das 15 mães entrevistadas, e os agravos à saúde a que está sujeito por ser fumante, sob o ponto de vista epidemiológico, apresentou-se como uma visão superficial e distante 
A troca de saberes com a população e a adequação às suas estruturas sociais e culturais, que podem ser, portanto, investigadas com esses discursos, apóiam a promoção da saúde, principalmente voltada às ações educativas. Assim, os benefícios da abordagem educativa podem se estender não apenas ao indivíduo/criança como também ao grupo familiar.

Para apoiar essas ações educativas, aparecem em destaque a escola e o professor, reforçando a possibilidade investigativa de coleta de dados que poderão nortear um trabalho sólido de prevenção e promoção de saúde.

Também porque, segundo AQUINO (in SAYÃO e AQUINO, 2004, p. 109)

... existem três tipos de seres humanos: os que inventam o conhecimento, os que usufruem do conhecimento, e uma categoria muito especial: aqueles que recriam com os mais novos o que foi legado por todos. Esses últimos são os professores. Aqueles que cuidam dos que vão ficar.

Uma característica importante também dessa abordagem é o reconhecimento do "entorno", ou seja, o ambiente social próximo da criança, como elemento que se aproxima do paradigma de promoção da saúde.

A atenção e foco da luta antitabagismo, voltada ao ambiente escolar e ao papel do professor, reforça a iniciativa de fortalecer as escolas promotoras da saúde como aliadas na busca de comunidades e municípios saudáveis. Pensando numa real contribuição para o estabelecimento dessa aliança é que pretendemos direcionar esta investigação. 


\section{OBJETIVOS}

"Não há entrada já aberta para a ciência e só aqueles que não temem fadiga de galgar suas escarpas abruptas é que têm a chance de chegar a seus cimos luminosos".

(MARX, 1983, p. 23) 


\subsection{Objetivo Geral}

Investigar a Representação Social dos professores de duas escolas de Ensino Fundamental II, da rede pública estadual do município de São Paulo, frente a ações de controle do tabagismo na escola.

\subsection{Objetivos Específicos}

- Pesquisar o conhecimento desses professores sobre os prejuízos causados pelo fumo aos fumantes e aos fumantes passivos.

- Investigar a atitude desses professores frente às questões do tabagismo na escola.

- Analisar as representações desses professores quanto ao ato de fumar de seus alunos.

- Investigar como esses professores percebem seu papel no controle do tabagismo na escola.

- Investigar como, na visão desses professores, o tabagismo poderia ser abordado na escola. 


\section{Material e Métodos}

"Uma jornada de duzentos quilômetros começa com um simples passo" Provérbio Chinês 


\subsection{Escolha da população alvo}

O presente estudo foi desenvolvido em duas escolas públicas de Ensino Fundamental II da Diretoria Centro, pertencentes à rede estadual do município de São Paulo, com a aprovação do Comitê de Ética em pesquisa da Faculdade de Saúde Pública da Universidade de São Paulo.

Por ser uma instituição de importância social na formação dos indivíduos e estando o professor diretamente inserido no contexto diário dessas escolas, torna-se significativo reconhecer sua atuação como elemento disponível ao diálogo na prevenção do tabagismo e promoção da saúde da comunidade.

Por se tratar de amostra intencional, todos os 39 professores de $5^{\mathrm{a}}$ a $8^{\mathrm{a}}$ série do Ensino Fundamental das escolas escolhidas que mostraram disponibilidade e aquiescência para responder às perguntas, preenchendo o termo de consentimento (Anexo 1), foram submetidos a uma entrevista direta gravada.

Com o propósito de obter a maior aproximação possível da realidade local, procuramos manter em sigilo a identidade dos entrevistados e de suas escolas.

A preocupação na identificação das representações sociais de uma população que está em estreito contato diário com crianças e adolescentes que segundo ROSEMBERG, 1987 cada vez mais cedo, estão iniciando o tabagismo é de suma importância. Poder agir, portanto, nessa faixa etária, impedindo os jovens de ingressarem na experiência do tabaco nos parece relevante, já que esse hábito pode se instalar por múltiplas motivações sociais e psicológicas.

O termo de compromisso apresentado no ato da entrevista (Anexo 2) colocou claramente aos entrevistados a intenção do pesquisador de somente utilizar as declarações em pesquisa de divulgação científica, resguardando a confidencialidade e o sigilo da identidade dos depoentes.

Os estabelecimentos de ensino também foram formalmente esclarecidos sobre o objetivo da pesquisa e puderam conceder seu consentimento na coleta dos dados frente à assinatura de um documento comprobatório. 


\subsection{Procedimentos metodológicos}

Os dados foram colhidos por meio de um roteiro de entrevista individual direta semi-estruturada gravada (Anexo 4). Sua aplicação aos professores ocorreu na própria escola durante os meses de agosto a novembro de 2006, em ambiente adequado, atendendo a uma proposta metodológica de corte qualiquantitativo.

As entrevistas transcorreram em clima cordial, excluído de intervenções de juízo de valor por parte do entrevistador, até se esgotarem os relatos dos atores de maneira espontânea, durando de 10 a 35 minutos aproximadamente.

O roteiro da entrevista foi pré-testado com professores de escolas não participantes da pesquisa, como instrumento de averiguação das dificuldades de entendimento das perguntas ou mesmo de quaisquer outras possíveis falhas que pudessem dificultar o levantamento dos discursos.

O conteúdo gravado nas entrevistas foi, posteriormente, transcrito de forma integral e literal pela própria autora desta tese.

$\mathrm{Na}$ ocasião, foi também aplicado questionário individual ao professor, visando explicitar características do entrevistado (Anexo 3).

A análise dos discursos produzidos pelos pesquisados apoiou-se na técnica qualiquantitativa de representação social, denominada Discurso do Sujeito Coletivo, proposta por LEFÈVRE e col. (2000).

O conceito de Representação Social aqui adotado refere-se à teoria inaugurada por MOSCOVICI (1978) e mais recentemente explorada por autores brasileiros.

Essa teoria tem sido um valioso instrumento para a compreensão das concepções do senso comum sobre diferentes aspectos relacionados à saúde, também porque, segundo MAINGUENEAU (2000), todo discurso é recoberto pela memória de outros discursos.

A memória, por sua vez, é uma construção social, um processo psicossocial de representação de si mesmo que fornece quadros de orientação e códigos para classificação e para intercâmbio social (MENEZES, 1992). 
FLICK (1995) observa que, apesar de existirem outras abordagens para a investigação das concepções de saúde e doença, os estudos fundamentados nas representações sociais podem dar sua contribuição pela necessidade atual de entender o binômio saúde/doença para além da questão individual.

O Discurso do Sujeito Coletivo, proposto por LEFÈVRE e col. (op.cit.), implica em analisar a utilização de figuras metodológicas elaboradas para ajudar a organizar e tabular os depoimentos permitindo, assim, a construção de seus discursos. Portanto, essas abordagens podem ser assim expressas:

Ancoragem: quando é possível encontrar nele traços lingüísticos explícitos de teorias, hipóteses, conceitos e ideologias existentes na sociedade e cultura interiorizados no indivíduo.

Idéia central: afirmações que permitem traduzir o essencial do discurso explicitado pelo sujeito em seus depoimentos.

Expressões - chave: são constituídas por transcrições literais de partes dos depoimentos, que permitem o resgate do essencial do discurso.

Discurso do sujeito coletivo (DSC): discurso que se elabora a partir do processamento dos depoimentos colhidos pelo pesquisador, resultando em um único discurso que traduz como os indivíduos reais pensam.

Os DSC construídos podem ser posteriormente quantificados, através dos atributos Intensidade e Amplitude, que poderão traduzir a freqüência das idéias levantadas e seu grau de abrangência.

A analise dos depoimentos destes professores permitiu a apreciação quantitativa segundo a variável intensidade, medida pela freqüência de respostas categorizadas em cada idéia central. Esse atributo mostrou o grau de compartilhamento de uma mesma idéia.

Pelo fato de estarmos trabalhando com todos os professores das duas escolas selecionadas, sem excluir da pesquisa aqueles que manifestaram o hábito de fumar, agrupamos em uma categoria específica este profissional, a cada vez que ele se identificava como fumante em seus discursos durante as diferentes perguntas formuladas. 
A amplitude, que se refere à dispersão de uma mesma idéia central entre diferentes grupos, não foi aqui analisada dado que consideramos apenas um grupo de estudo, isto é, o grupo de professores de duas escolas pertencentes à Diretoria Centro da região sudeste de São Paulo.

Em auxílio à tarefa da construção dos DSCs, foi aqui utilizado como recurso o Qualiquantsoft. Trata-se de um programa de computador elaborado pela Universidade de São Paulo, com a supervisão dos professores Fernando Lefèvre e Ana Maria Cavalcanti Lefèvre, em parceria com uma empresa de informática. (SPi - Sales \& Paschoal Informática, 2007)

Embora representando um avanço importante para esse tipo de pesquisa, é importante salientar que, enquanto recurso facilitador, esse instrumento não substitui o papel do pesquisador. Também porque a utilização do software em questão exige categorização de idéias centrais que apenas podem ser organizadas sob o olhar do pesquisador. Um exemplo do resultado da aplicação direta do Qualiquantsoft pode ser observado no anexo 5 deste trabalho.

O universo dos discursos, elaborados a partir das representações dos professores deste estudo, poderá constituir um material repleto de impressões que trarão orientações para um caminhar mais audacioso, ou talvez até mesmo mais efetivo no combate ao tabagismo. 


\section{Resultados}

“...trabalhar o velho para renová-lo até o limite"

Boaventura de Souza Santos 


\subsection{Caracterização dos entrevistados}

Ao iniciarmos a apresentação dos resultados, é pertinente identificar características individuais dos professores entrevistados (anexo 3) .

No que se refere ao grau de escolaridade, sendo a pesquisa voltada a professores de escola de nível fundamental II, foi constatado que todos os 39 envolvidos apresentavam nível superior completo atendendo à legislação vigente para o exercício da

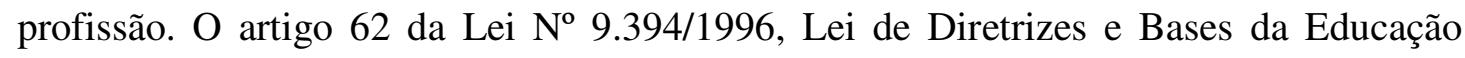
Nacional (LDB) estabelece que: “A formação de docentes para atuar na educação básica far-se-á em nível superior, em curso de licenciatura, de graduação plena, em universidades e institutos superiores de educação...”.

A distribuição por gênero (Figura 1) indica um índice de $70 \%$ para o sexo feminino e 30\% para o sexo masculino, confirmando levantamentos estatísticos anteriores. Uma pesquisa realizada pela UNESCO em 2002 apontou 81,3\% de mulheres para $18,7 \%$ de homens, evidenciando a predominância feminina, principalmente no ensino fundamental (UNESCO, 2004).

FIGURA 1 - Distribuição da proporção (\%) dos professores entrevistados segundo sexo. São Paulo, 2006.

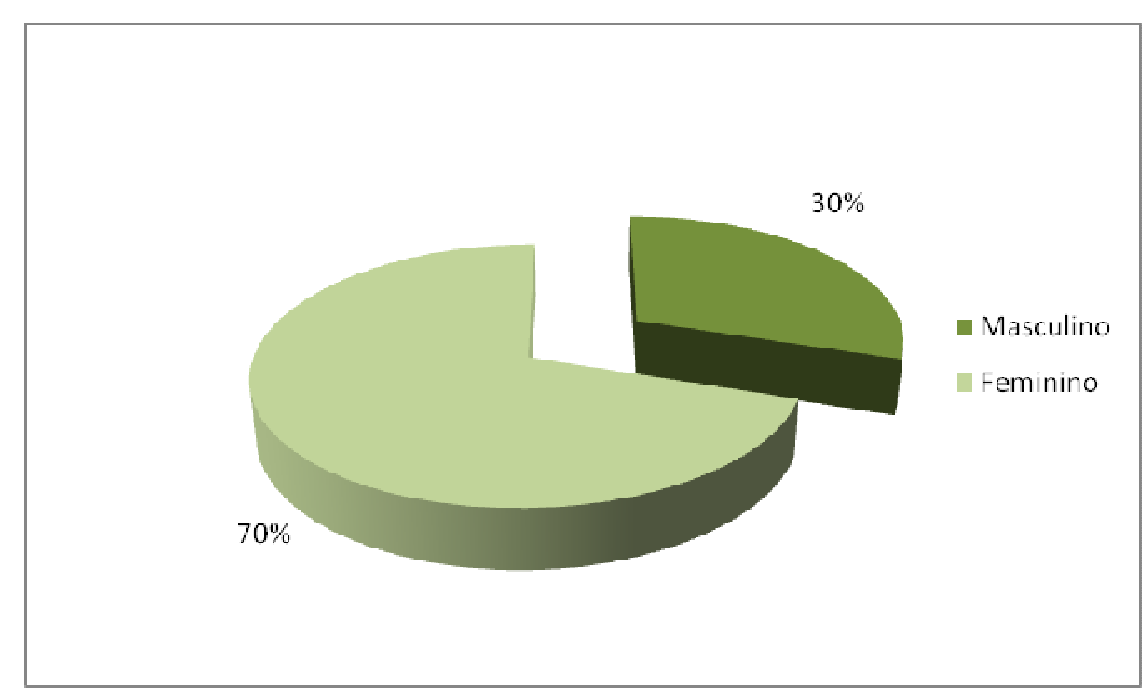


Quanto ao hábito de fumar, encontramos a porcentagem de $87 \%$ de não-fumantes entre os entrevistados, dado relevante para análise dos discursos obtidos, já que o levantamento foi pautado na opinião pessoal dos professores quanto ao tabagismo e à atuação deles frente ao tema (Figura 2).

FIGURA 2: Distribuição da proporção (\%) de professores quanto ao hábito de fumar. São Paulo, 2006.

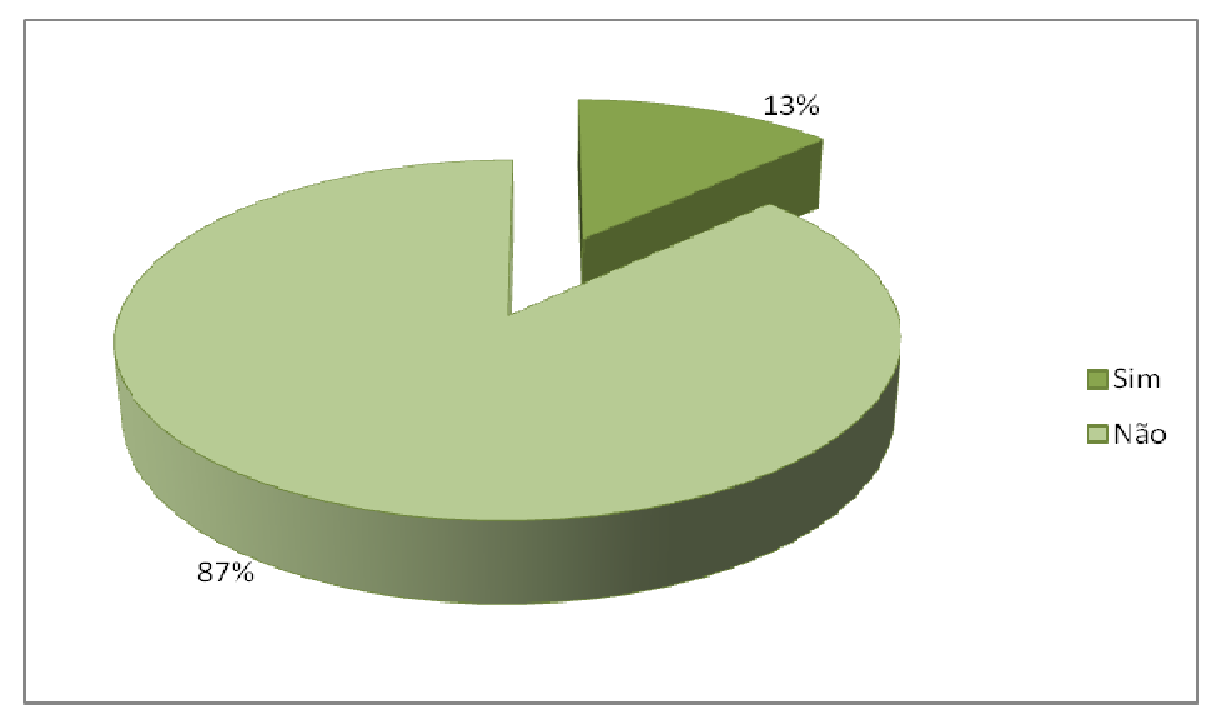

$\mathrm{Na}$ distribuição em porcentagem que evidencia a faixa etária dos professores (Figura 3) é possível notarmos a maior concentração dos entrevistados entre as idades de 31 e 50 anos. O índice de $74 \%$ pautado sobre esse número de anos caracteriza uma população que traz consigo uma experiência prévia de vida, podendo assim oferecer depoimentos que revelam uma grande diversidade de situações vivenciadas. 
FIGURA 3: Distribuição da proporção (\%) dos entrevistados segundo idade. São Paulo, 2006.

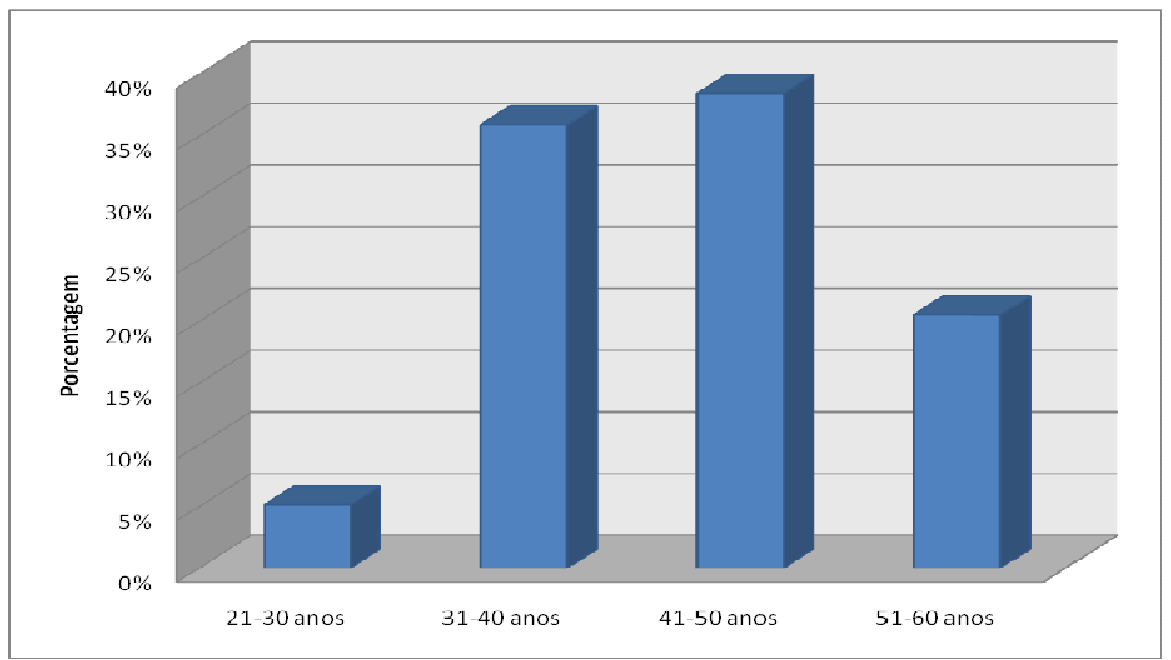

Em relação às escolas onde os professores ministram aulas, constatamos que $82 \%$ deles pertenciam exclusivamente à rede pública de ensino (Figura 4), o que aproxima a pesquisa da visão desse tipo de profissional e de seu ambiente de trabalho.

FIGURA 4: Distribuição da proporção (\%) de professores segundo exercício do cargo. São Paulo, 2006.

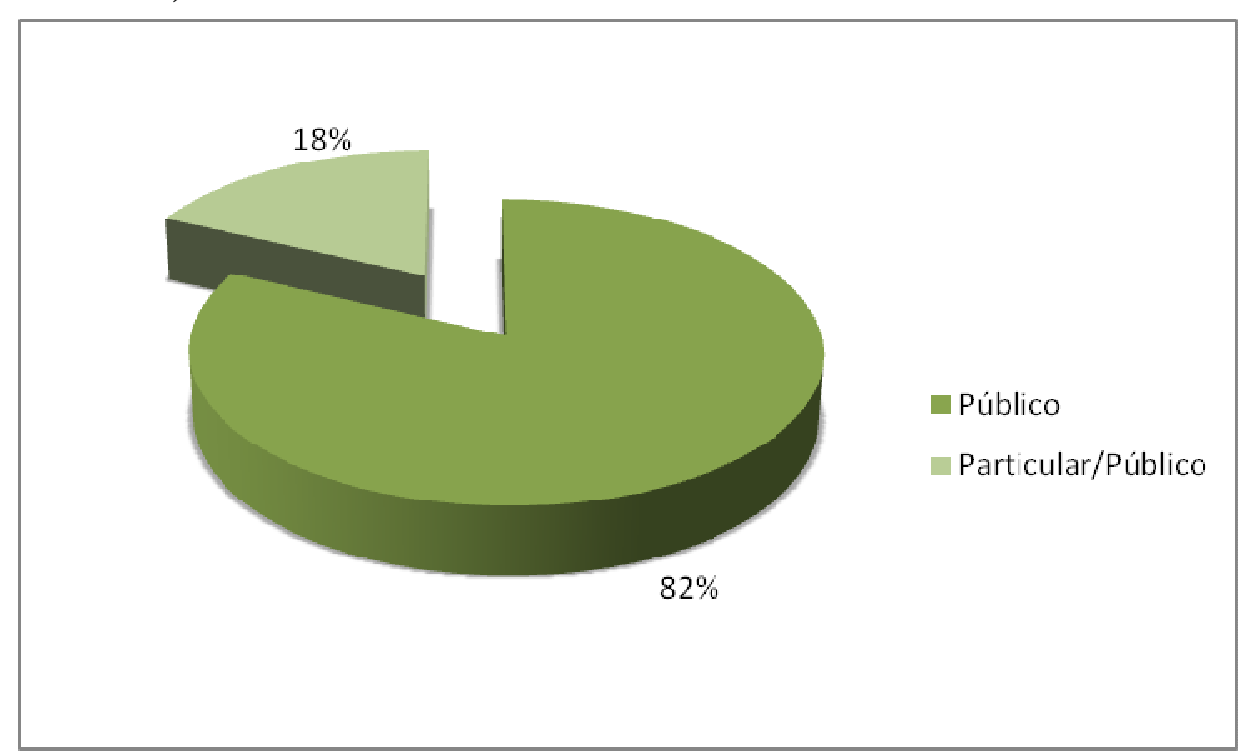


A distribuição de professores por área de atuação na escola mostra que as maiores porcentagens estão concentradas nos componentes curriculares Português e Matemática, isto se deve ao maior número de aulas que compõem a matriz curricular do Ensino Fundamental, exigindo, assim, mais especialistas nessas áreas (Figura 5).

FIGURA 5: Distribuição da proporção (\%) dos entrevistados segundo componente curricular. São Paulo, 2006.

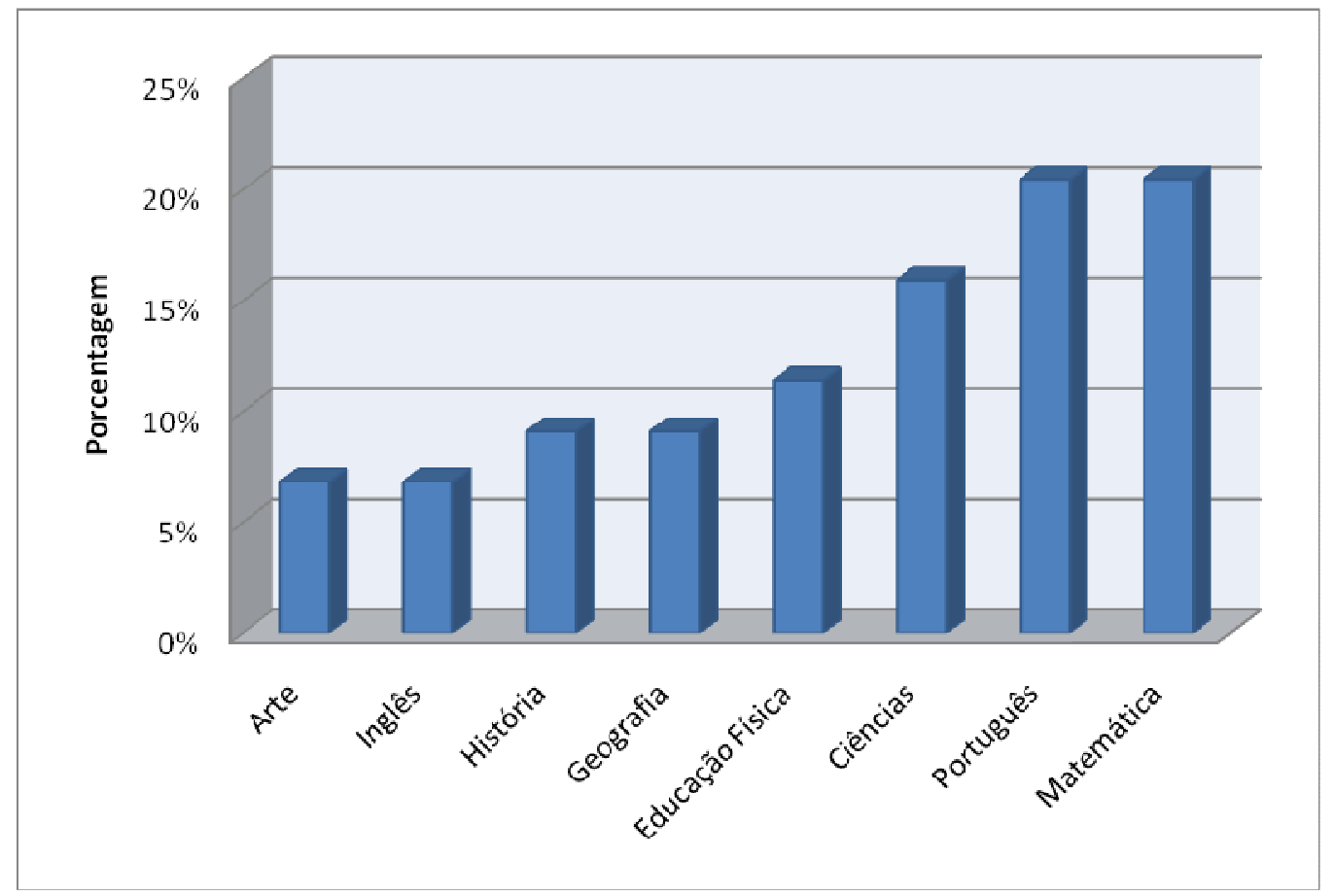

Recentemente, a Secretaria Estadual de Educação, reforçando o compromisso com as habilidades e competências específicas de cada componente curricular da Base Nacional Comum, implantou a Resolução $N^{\circ}$ 92/ 2007 (quadro a seguir), mantendo assim maior atenção à Língua Portuguesa e Matemática. 


\section{RESOLUÇÃO No 92 DE 19 DE DEZEMBRO DE 2007}

Estabelece diretrizes para a organização curricular do ensino fundamental e médio nas escolas estaduais.

\begin{tabular}{|c|c|c|c|c|c|c|}
\hline \multicolumn{7}{|c|}{ Matriz Curricular Básica - Ensino Fundamental } \\
\hline \multicolumn{7}{|c|}{ Ciclo II - 5a A $8^{\text {a }}$ Série Diurno com Dois Turnos e Período Noturno* } \\
\hline \multirow{2}{*}{\multicolumn{2}{|c|}{ Disciplinas }} & \multicolumn{5}{|c|}{ Séries / Aulas } \\
\hline & & $5^{\mathrm{a}}$ & $6^{\mathrm{a}}$ & $7^{\mathrm{a}}$ & $8^{\mathrm{a}}$ - Diurno & $8^{\text {a Noturno }}$ \\
\hline \multirow{8}{*}{$\begin{array}{c}\text { Base } \\
\text { Nacional } \\
\text { Comum }\end{array}$} & L. Portuguesa & 5 & 5 & 5 & 5 & 5 \\
\hline & Arte & 2 & 2 & 2 & 2 & 2 \\
\hline & $\begin{array}{l}\text { Educação } \\
\text { Física** }\end{array}$ & 2 & 2 & 2 & 2 & 2 \\
\hline & História & 2 & 2 & 2 & 2 & 2 \\
\hline & Geografia & 2 & 2 & 2 & 2 & 2 \\
\hline & Matemática & 5 & 5 & 5 & 5 & 5 \\
\hline & $\begin{array}{c}\text { Ciências Físicas } \\
\text { e Biológicas }\end{array}$ & 2 & 2 & 2 & 2 & 2 \\
\hline & $\begin{array}{c}\text { Ensino } \\
\text { Religioso }\end{array}$ & & & & 1 & 1 \\
\hline $\begin{array}{c}\text { Parte } \\
\text { Diversificada }\end{array}$ & $\begin{array}{c}\text { Língua } \\
\text { Estrangeira } \\
\text { Moderna }\end{array}$ & 2 & 2 & 2 & 2 & 2 \\
\hline \multicolumn{2}{|c|}{ Total Geral } & $22+5=27$ & $22+5=27$ & $22+5=27$ & $* 23+5=28$ & $* 22+5+27$ \\
\hline \multicolumn{7}{|c|}{$\begin{array}{l}\text { *Distribuir, em cada série do período diurno, as } 05 \text { aulas semanais entre as disciplinas constantes da } \\
\text { matriz curricular, à exceção de Educação Física e Ensino Religioso. No período noturno, distribuir, em } \\
\text { cada série, } 05 \text { aulas semanais quando Ensino Religioso não comportar turma de alunos e } 4 \text { (quatro) } \\
\text { quando esse componente comportar turma específica. } \\
\text { **Educação Física será ministrada, dentro do horário regular de aulas, no período diurno, e fora desse } \\
\text { horário, no período noturno. }\end{array}$} \\
\hline
\end{tabular}

Fonte: SEE/SP/lise, 2008

Além disso, por ocasião da coleta dos dados desta pesquisa, contribuiu também para essa concentração de profissionais a vigência da Resolução SE 16, de 1-3-2005, que dispõe sobre aulas complementares de enriquecimento curricular na rede estadual de ensino (Projeto de Leitura), tendo em seu Artigo 50: "As aulas serão atribuídas pelo diretor da escola a docentes em exercício na unidade escolar ou admitidos para esse fim, 
portadores de licenciatura plena, habilitados preferencialmente em Língua Portuguesa, nos termos da Resolução SE nº 135/2003".

De acordo com os dados obtidos (Figura 6), apenas 16\% dos professores aqui entrevistados ocupavam o cargo há 21 e 30 anos de profissão. Entre os demais, $45 \%$ e $39 \%$ estavam no magistério há, no máximo, 10 e entre 11 e 20 anos, respectivamente.

FIGURA 6: Distribuição da proporção (\%) dos professores segundo tempo em anos de exercício da profissão. São Paulo, 2006.

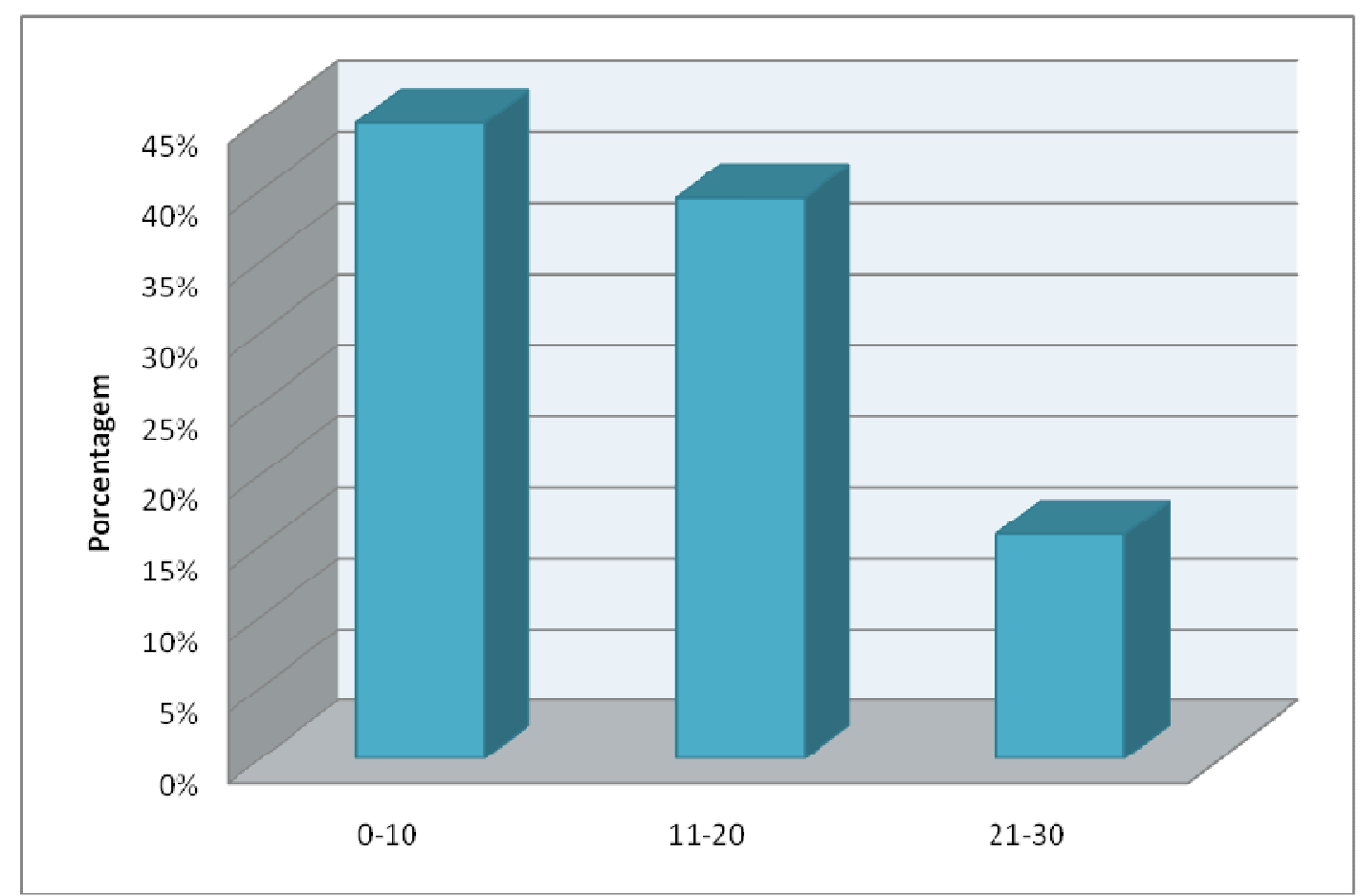

O fato de ministrar aulas no ensino fundamental apenas ou concomitantemente no ensino médio (Figura 7) pôde trazer um enriquecimento aos depoimentos, já que o profissional mantinha uma aproximação com indivíduos de faixas etárias diferentes. 
FIGURA 7: Distribuição da proporção (\%) dos professores por nível de ensino no exercício do magistério. São Paulo, 2006.

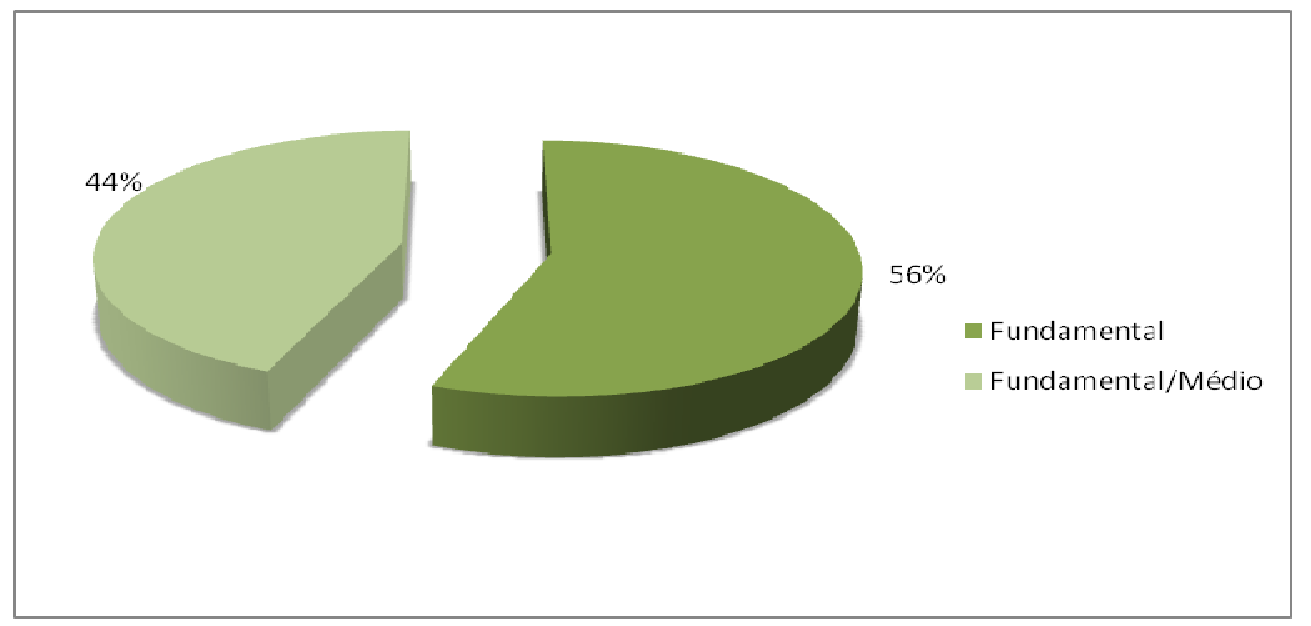

Quanto ao estado conjugal dos entrevistados (Figura 8), 51\% deles eram casados, $44 \%$ solteiros e os viúvos e divorciados compunham, ambos, apenas 2,5\% da amostra.

FIGURA 8: Distribuição da proporção (\%) de professores segundo estado conjugal. São Paulo, 2006.

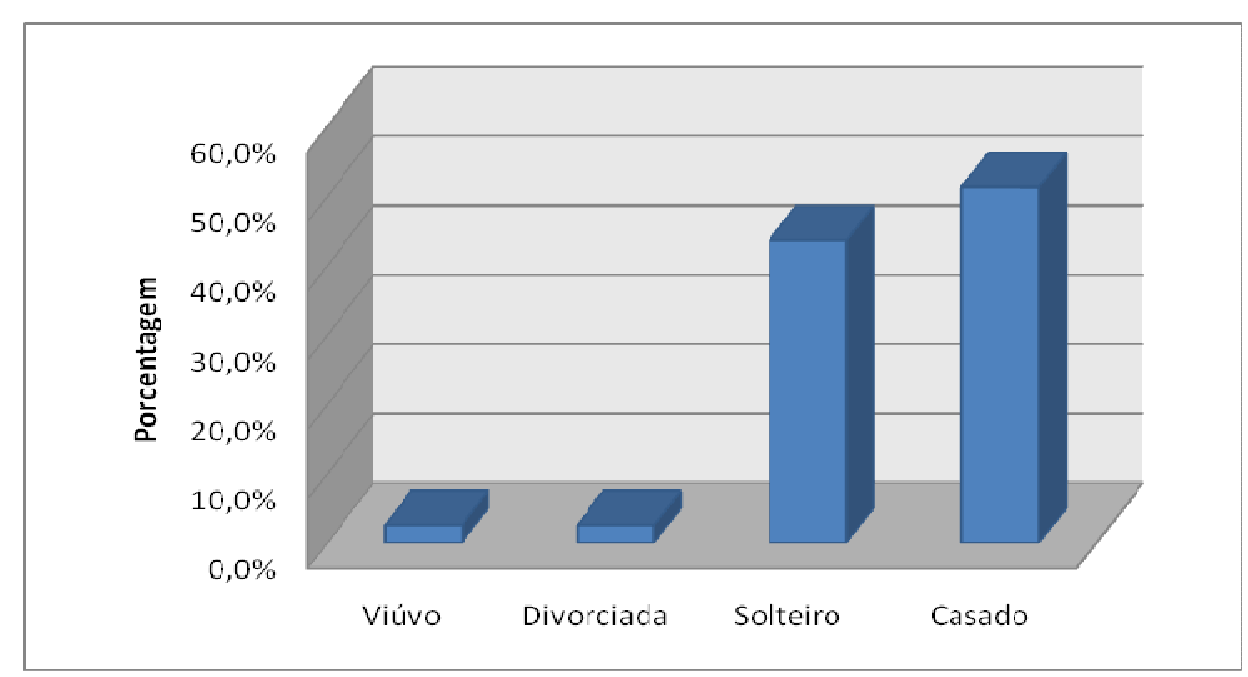


Em relação ao número de filhos dos entrevistados (Tabela 1), 41\% deles não possuíam filhos e 43,5\% informaram ter apenas um ou dois filhos.

Tabela 1: Distribuição em número e proporção (\%) dos professores segundo o número de filhos. São Paulo, 2006.

\begin{tabular}{c|cc}
\hline Número de Filhos & Número & \% \\
\hline 0 & 16 & 41,0 \\
1 & 9 & 23,0 \\
2 & 8 & 20,5 \\
3 & 5 & 13,0 \\
4 & 1 & 2,5 \\
\hline Total & $\mathbf{3 9}$ & $\mathbf{1 0 0}$ \\
\hline
\end{tabular}

Quanto à faixa etária, a maior porcentagem foi revelada nos intervalos entre $21 \mathrm{e}$ 30 anos, o que caracteriza uma grande vivência familiar com as diferentes fases de crescimento de uma criança (Tabela 2).

Tabela 2: Distribuição do número e proporção $(\%)$ de professores ${ }^{*}$ segundo faixa etária dos filhos. São Paulo, 2006.

\begin{tabular}{c|cc}
\hline Idade dos Filhos & Número & \% \\
\hline $0-10$ anos & 9 & 32,0 \\
$11-20$ anos & 9 & 32,0 \\
$21-30$ anos & 10 & 36,0 \\
\hline Total & $\mathbf{2 8}$ & $\mathbf{1 0 0}$ \\
\hline
\end{tabular}

*possibilidade do mesmo professor ter filhos em faixas etárias diferentes.

A renda mensal familiar dos entrevistados pode ser observada na Tabela 3: 
Tabela 3: Número e proporção (\%) de professores segundo renda mensal familiar em reais. São Paulo, 2006.

\begin{tabular}{c|cc}
\hline Renda Familiar Mensal & Número & \% \\
\hline $\mathrm{R} \$ 1.000-2.900$ & 12 & 37,5 \\
$\mathrm{R} \$ 3.000-4.900$ & 12 & 37,5 \\
$\mathrm{R} \$ 5.000-$ ou mais & 8 & 25,0 \\
\hline Total & $\mathbf{3 2}^{*}$ & $\mathbf{1 0 0}$ \\
\hline
\end{tabular}

*sete professores não informaram sua renda.

\subsection{Apresentação dos Discursos do Sujeito Coletivo}

Optamos por apresentar os resultados quantitativos desta pesquisa apoiados na proporção de professores, de acordo com as respostas dadas a cada pergunta feita durante a entrevista. Desta forma, acreditamos oferecer uma visão maior da abrangência das respostas entre o público analisado.

Os discursos foram produzidos na primeira pessoa, a partir do agrupamento das idéias centrais categorizadas pelo pesquisador, após exaustiva leitura.

A primeira pergunta apresentada aos professores entrevistados foi: "O que é fumar para você? Fale um pouco sobre isso para mim."

Com esse questionamento, o pesquisador procurou identificar o grau de aproximação e aceitação do cigarro pelos professores no seu dia-a-dia.

A distribuição das idéias centrais em porcentagens, segundo o número de respostas a primeira pergunta, “O que é fumar para você? Fale um pouco sobre isso para mim", podem ser observada na Tabela 4 e Figura 9: 
Tabela 4: Numero e proporção (\%) de respostas dadas pelos professores de acordo com as Idéias Centrais" da pergunta "O que é Fumar para você? Fala um pouco disso para mim" São Paulo,2006.

\begin{tabular}{lcc}
\hline \multicolumn{1}{c}{ Idéias Centrais } & no & \% $^{* *}$ \\
\hline É um vício & 10 & 26 \\
Prazer que faz mal & 4 & 10 \\
Traz malefícios & 17 & 44 \\
Suprir necessidades, se ocupar & 12 & 31 \\
Falta de educação & 3 & 8 \\
Perda de tempo. Sou contra & 3 & 8 \\
Não sei, não fumo & 4 & 10 \\
Não tenho problemas com ele & 1 & 3 \\
Sou fumante, criei este hábito & 3 & 8 \\
\hline \multicolumn{1}{c}{ TOTAL } & $\mathbf{5 7}$ & \\
\hline
\end{tabular}

*possibilidade de mais de uma Idéia Central por indivíduo.

** calculada em relação ao total de professores.

FIGURA 9: Proporção (\%)* de respostas dadas pelos professores de acordo com as Idéias Centrais da pergunta " $O$ que é Fumar para você? Fala um pouco disso para mim” São Paulo, 2006.

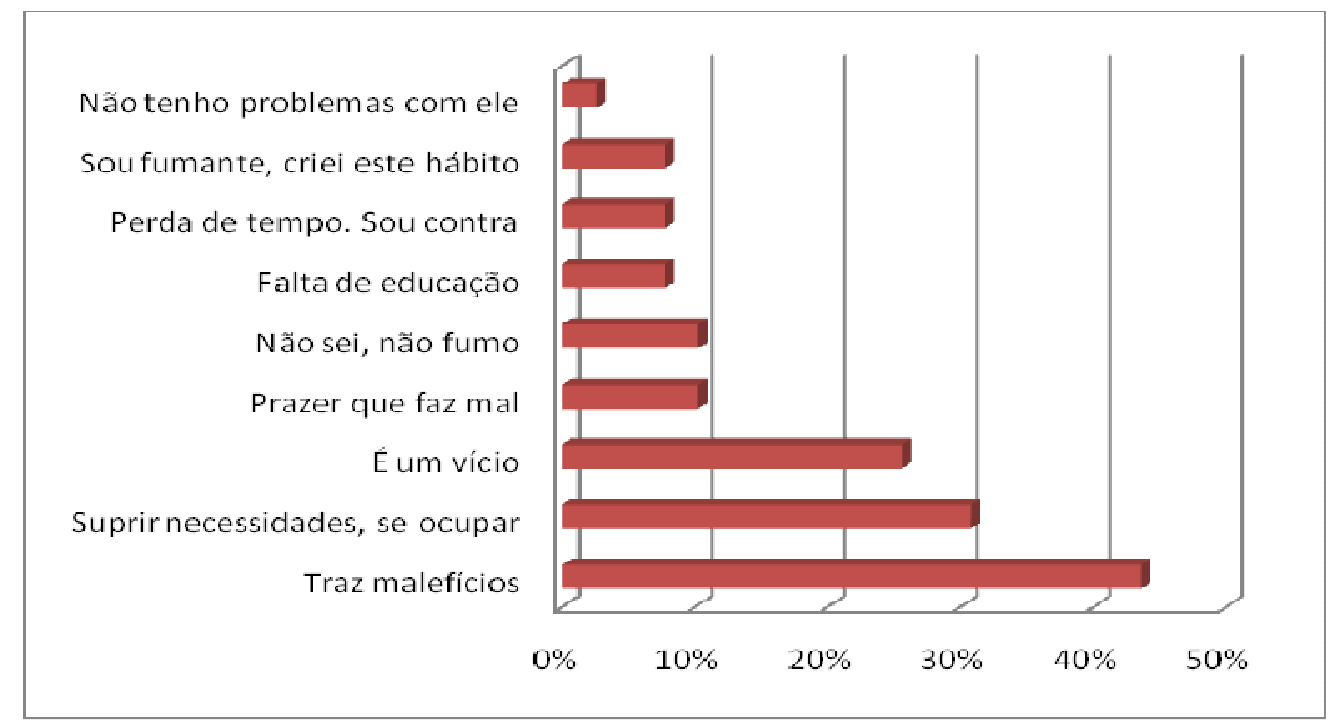

*calculada pelo número total de professores. 


\section{DSC obtidos a partir da pergunta 1: "O que é fumar para você? Fale um pouco sobre isso para mim".}

\section{IDÉIA CENTRAL A - É um vício.}

Bom, fumar é um vício que... Como beber, como usar droga, feito uma maconha, uma cocaína. Como qualquer outro, faz com que você fique dependente dele.

Individualmente é uma dependência, porque é nítido que a pessoa se torna dependente é... ansiosa, né ? Dependente químico inclusive. E o fumante ele busca uma afirmação social. Então socialmente é como se fosse liberdade e individualmente é como se fosse dependente, mas eu não gosto. Trabalhei sete anos com uma pessoa que fumava, eu aqui e ela ali, então eu fumei quase que praticamente indiretamente, né? E não gosto do cheiro de cigarro. Tem alunos que aparecem por aí com cheiro de cigarro, eu percebo na hora. Aí a gente tenta conversar com os alunos aqui, de treze, quatorze anos, mas eu acho que quando você começa com esse vício vai ser difícil você parar.

Conheço pessoas que acham difícil mesmo. Param de fumar, aí engorda, caem em depressão, tem vários outros problemas, né? É uma coisa muito ruim pra quem fuma, mas talvez teria até sido melhor continuar fumando.

Eu acho que não tem nenhuma necessidade. A pessoa não precisa desse vício para nada. Além da questão da saúde daquele que ta recebendo aquela fumaça, não é ativo, mas fuma passivamente, né? Eu acho extremamente prejudicial. E não só físico, como emocional.

Algumas comidas, algumas bebidas fazem com que eles fumem mais ainda. E é um mal que existe há muito tempo.

Hoje em dia tá piorando por causa de, até da própria qualidade do cigarro. Porque tem muitas misturas, muitas coisas além do tabaco, que eles colocam ali.

Então, eu não tenho nada de bom pra dizer a respeito do cigarro não. Traz vários problemas pra pessoa.

\section{IDÉIA CENTRAL B - Prazer que faz mal.}

Fumar nos da uma sensação de bem estar, um certo prazer. Momentâneo, bastante pequeno, né? Pra mim pessoalmente é um prazer. Eu sei que faz mal, eu não posso porque eu tenho bronquite, tenho diabetes, mas me dá prazer. E eu não fumo nada assim, mas fumo. Sei de todos os males, reconheço que incomoda as outras pessoas.

Tem momentos que eu não posso ta fumando, quando ta trabalhando. Eu não posso ta fumando em alguns locais que não são permitidos, mas eu gosto de fumar, esse é o problema. 


\section{IDÉIA CENTRAL C - Traz malefícios.}

Eu acho que fumar, pra mim, é desperdício de dinheiro e de saúde. É não respeitar o corpo, porque a gente não vê ninguém que fuma, que nem, um exemplo que eu tenho: minha mãe foi fumante. Hoje ela tem 77 anos, correto, e tem problemas de pulmão porque ela fumou praticamente 50 anos da vida dela.

Então isso trouxe prejuizo, hoje ela ta com insuficiência pulmonar devido aos anos que ela fumou. Por ela ter morado na roça, ela disse que pra afastar percevejo essas coisas, o pai ensinou a fazer o cigarrinho de palha e o vício ficou nela. Hoje faz 20 anos que ela parou de fumar.

Eu acho que é a degradação do próprio corpo. É você inalar substância que não é natural, entendeu. Que não tá na natureza disponível de modo natural. É inalar fumaça com tantos derivados aí, né? Tóxicos, que têm dentro do cigarro e outras coisas mais de drogas.

É uma autodestruição e faz mal também até quem fica perto, porque geralmente quem fuma não se dá conta de muitas das pessoas que estão ao seu lado não se interessam pela fumaça do seu cigarro.

Quer dizer, não é só por o cigarro na boca, o cara tá com cigarro na boca, e quem tá perto dele também tá fumando. Não tem sentido nenhum.

Não gosto do cheiro, é um hábito péssimo, que faz mal pra saúde a curto, a médio e a longo prazo. Então deveria ser radicalmente cortado porque as pessoas não têm consciência.

O que tá acontecendo é que com tanta informação que se tem hoje o jovem continua fumando. Mantendo esse hábito, que é péssimo. Eu acho que fumar é uma coisa desagradável.

Há uma possibilidade de pesquisa que ele realmente provoca câncer, e quem não fuma, que é o fumante passivo, tem grande probabilidade de ter câncer. Muito mais do que quem fuma.

Agora não é porque eu vou ver uma pessoa com o cigarro que precisa brigar, não sou moralista. Sei lá, tudo tem o seu momento, sua hora, desde que ela fume em local apropriado. Eu procuro ficar bem longe de quem fuma. Eu não gosto e eu vejo dessa forma.

\section{IDÉIA CENTRAL D - Suprir necessidades, se ocupar.}

Fumar em minha opinião é uma atividade. Até pouco tempo atrás eu achava até que era uma atividade de distração. Mas é uma maneira infeliz de se ocupar. É uma saída, como se diz, é a busca de algum tempero da vida, é uma necessidade que algumas pessoas têm de extravasar seu nervosismo, seu estresse.

Tem pessoa que fuma quando tá nervosa. Como algumas pessoas que descontam a ansiedade em outras coisas. Tem a necessidade de preencher um vazio na sua vida, né? 
Descarregar suas emoções de alguma maneira, afogar alguma mágoa e eu acho que cada um foge dos seus problemas de uma forma. Fumar é uma delas, o problema é que não é uma forma saudável.

As pessoas que fumam parecem que elas estão descontando no cigarro alguma frustração, mas é um ato errado, eu não concordo.

Eu não gosto, eu acho que as pessoas que fumam são sempre aquelas que procuram se colocar numa condição melhor, aquela postura, quem fuma tem status. Ou, por exemplo, tá sempre armada, tá sempre se defendendo de alguma coisa, não sei se quer chamar a atenção.

E pra quem já até experimentou, o fumar é o momento assim que às vezes você quer descontrair um pouco e você não leva em consideração todo o mal que pode causar. Então às vezes você fala, ah eu to cansada, to meio estressada então vou fumar um cigarro pra espairecer. E eu acho que tem muito a ver com ansiedade.

Então é isso que acontece. Muitas pessoas acabam fumando, ou por isso ou pela curiosidade, né? Pra saber como que é, principalmente na idade que eu aprendi a fumar. Eu aprendi só que hoje eu não fumo mais.

\section{IDÉIA CENTRAL E - Falta de educação.}

O que é fumar, é uma falta de educação muito grande. Todo fumante é antes de mais nada um mal educado.

Dependendo até dos lugares é meio até inconveniente. E fora o cheiro que fica nas pessoas e fora o mal que faz também, né?

Agora, o que eu acho mais estranho é o seguinte: Tem tanta propaganda em escola, tanto curso e você tem professor que fuma, tem funcionários que fumam, atende pais fumando e não tem nenhuma restrição ao uso de tabaco nas dependências da escola.

Você não tem nenhuma ação de diretoria da escola em relação ao cigarro. Aqui à noite, quando começou o supletivo, piorou neste sentido porque vinham os adultos, eles se achavam no direito de sair entre uma aula e outra pra fumar.

A molecada aqui de cima viu que o pessoal do EJA estava fumando, achou que tinha o direito de fazer a mesma coisa. Então eu acho que é um absurdo a escola não, quer dizer, ter uma teoria tão grande a respeito disso e permitir que professor fume ou que funcionário fume ou que aluno fume.

Eu fico até horrorizada quando eu vejo um professor de educação física fumar, né? E eu realmente não gosto. Às vezes até em ponto de ônibus, aquele povo jogando fumaça na gente. Eu acho assim uma falta de educação.

Não é porque é um lugar público que pode ficar jogando a fumaça na cara das pessoas. Tem que ter um lugar certo. É falta um pouco de educação.

\section{IDÉIA CENTRAL F - Perda de tempo. Sou contra.}

Fumar pra mim é horrível, eu sou totalmente contra o fumante. Fumar eu acho que é uma perda de tempo, é perder tempo de nossa vida. 
Eu acho que quando a pessoa começa a fumar, é porque falta... Ela é adolescente, ele é inseguro, então, infelizmente quando ele descobre tudo isso já tá viciado. Então, fumar pra mim é isso.

\section{IDÉIA CENTRAL G - Não sei, não fumo.}

Não sei. Não fumo, não gosto de jeito nenhum. Não curto essas coisas.

Olha, fumar eu acho que pra mim não significa absolutamente nada. Eu não vejo nenhum gosto, eu não consigo entender assim as pessoas que fumam. Não saberia te dizer coisa mais profunda. Em termos de fumar, bebida, eu não entendo nada. É porque dentro do meu meio social, dentro das pessoas que eu convivi desde adolescente, nunca convivi com pessoas assim. Então é bem fora do meu universo.

\section{IDÉIA CENTRAL H - Não tenho problemas com ele.}

Eu não tenho grandes problemas com o cigarro. Não é uma coisa que me agrida, não é uma coisa que me irrite muito, mas eu nunca comecei, eu nem sequer experimentei justamente por ser uma pessoa um pouco ansiosa e achar que eu ia me viciar nele.

\section{IDÉIA CENTRAL I - Sou fumante, criei este hábito.}

Ah, mas eu sou fumante. É complicado. Eu fumo já há muitos anos e eu criei este hábito, mas eu não sinto assim nada de bom nada de ruim.

O meu organismo pede, eu fumo. Eu acho que é um abuso da pessoa.

É um vício, né? É um vício, eu sou consciente disso, mas não tenho vontade de largar.

A pergunta dois, "Você acha que o cigarro afeta outras pessoas? O que você acha disso?", pretendeu identificar a presença do conceito "fumante passivo" entre os entrevistados.

A Tabela 5 e a Figura 10 explicitam as porcentagens de respostas obtidas para a pergunta: "Você acha que o cigarro afeta outras pessoas?, para cada Idéia Central categorizada. 
Tabela 5: Numero e proporção (\%) de respostas dadas pelos professores de acordo com as Idéias Centrais" da pergunta "Você acha que o cigarro afeta outras pessoas?" São Paulo, 2006.

\begin{tabular}{lccc}
\hline \multicolumn{1}{c}{ Idéias Centrais } & No & \% $^{* *}$ \\
\hline Sim, incomoda & 12 & 31 \\
Sim, o fumante passivo & 17 & 40 \\
Sim, prejudica quem tem problema respiratório & 6 & 15 \\
Sim, professor fumante dá mau exemplo & 1 & 3 \\
Sim, a saúde e o cheiro & 3 & 8 \\
Sim, filho de fumante tem problema & 1 & 3 \\
Sim, sei porque fumo & 4 & 10 \\
\hline \multicolumn{1}{c}{ Total } & $\mathbf{4 4}$ & \\
\hline
\end{tabular}

*possibilidade de mais de uma Idéia Central por indivíduo.

** calculada em relação ao total de professores.

FIGURA 10: Proporção $(\%)^{*}$ de respostas dadas pelos professores de acordo com as Idéias Centrais da pergunta "Você acha que o cigarro afeta outras pessoas?". São Paulo, 2006.

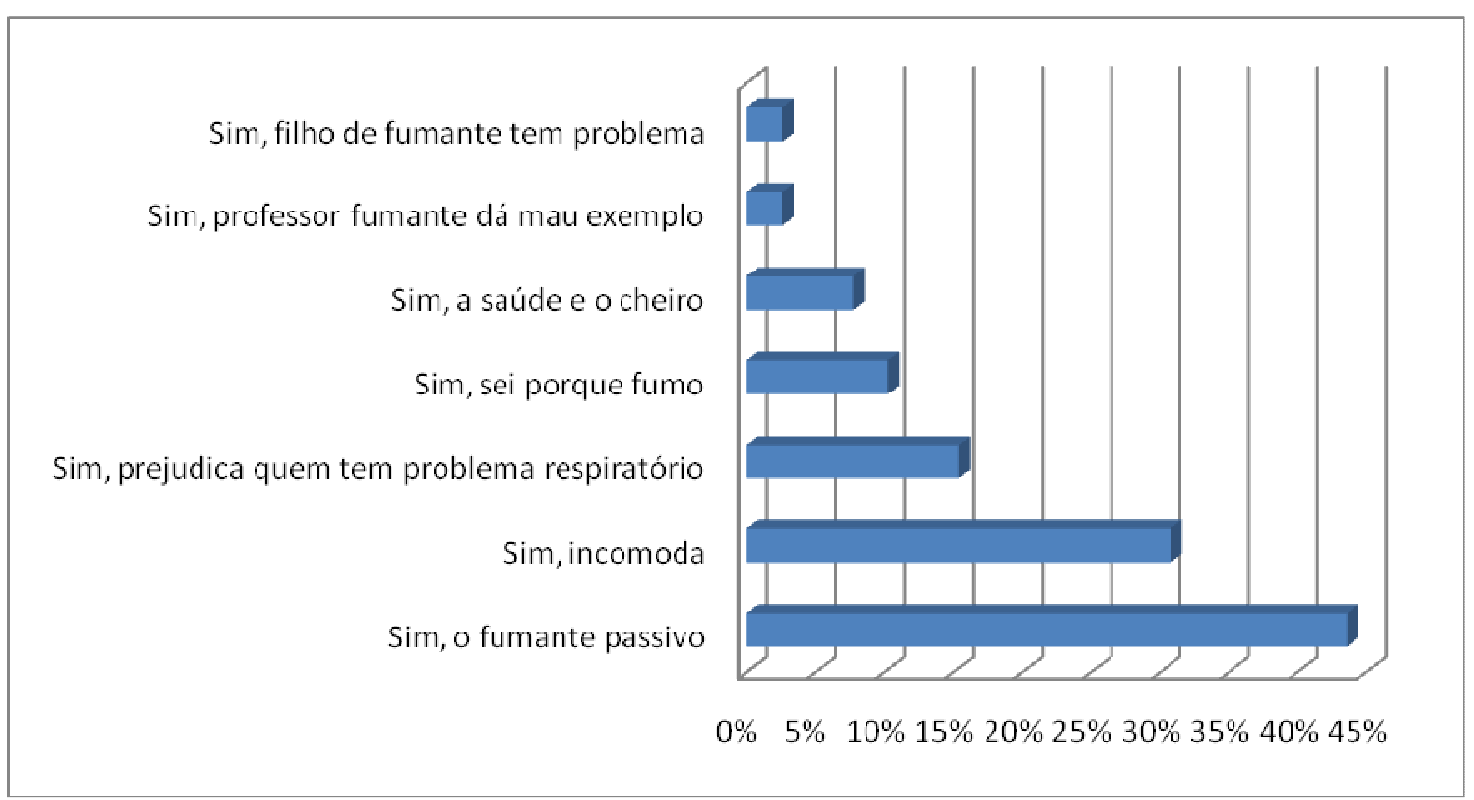

*calculada pelo número total de professores. 


\section{DSC obtidos a partir da pergunta 2: "Você acha que o cigarro afeta outras} pessoas?

\section{IDÉIA CENTRAL A - Sim, incomoda.}

Afeta sim. Nesse caso, as pessoas que são fumantes passivos. Que tiveram doenças sérias, inclusive câncer, né?

Sabe por que, eu digo assim? Quando nós estamos na fila de ônibus nós estamos em locais onde as pessoas fumam, o que que acontece, eu me sinto incomodada com a fumaça.

Às vezes, mesmo na sala dos professores, a pessoa entra fumando, além de ficar um mau cheiro, fica o resíduo também.

O cheiro do cigarro fica na minha roupa, você fica com o cabelo cheirando. Você vê, tem avisos não fume, proibido fumar, as pessoas não ligam e aquela fumaça não incomoda.

A mim, pelo menos, incomoda. Eu acho que essa lei de ter lugar pra fumante e não fumante devia prevalecer e muito, mas não essa mentira. Só se for um lugar fechado. E geralmente acontece isso em restaurante.

Porque se fica assim duas, três mesas no restaurante longe da pessoa não adiantam, a fumaça não tem como. Você tá no restaurante, termina de almoçar ou jantar e a pessoa do seu lado acende o cigarro. Ou você tá com criança. Prejudica demais o ambiente e as pessoas que fumam geralmente não respeitam os outros, né?

Até não sei a relação entre afetar e incomodar. Eu acho que por não fumar me incomoda bastante. Ás vezes até tem lugar que eu evito ir porque tem gente que fuma. Principalmente locais que são mais fechados, onde há aquela concentração da fumaça e não é uma situação muito agradável.

Por isso que eu acho que deveria mesmo ter um lugar separado pra quem fuma e pra quem não fuma. Eu sou contra as pessoas que não respeita quem tá do lado. É aquela coisa, eu não sou obrigada. Se ela quer fumar, tudo bem, problema dela. Mas a mim incomoda bastante.

Às vezes você não quer ser indelicado com a pessoa que tá fumando, que ela não percebe que ela tá te incomodando, então você acaba ficando no ambiente que não é agradável.

No contexto familiar, assim, meu marido fumou durante muitos anos. Foi um alívio ele ter parado de fumar. Então minha casa é mais até... Não é tão pesada, eu tô com a casa sempre arejada, sempre tranqüila, não preciso me preocupar em ficar abrindo e tirando cinzeiro. 


\section{IDÉIA CENTRAL B - Sim, o fumante passivo.}

Com certeza. Isso é provado cientificamente que a pessoa que fuma ela tem o... um certo nível de problemas internos, a nivel respiratório e o não fumante que convive com esse fumante ele acaba fumando por tabela.

É como a gente diz, você é um fumante passivo que ao mesmo tempo que a pessoa ativa tá fumando, passa também aquela fumaça, a nicotina passa pra você, então você sofre mais até do que a pessoa que tá fumando.

Acredito que existem situações limite como gravidez, a gente sabe todos os prejuízos. E, mesmo que de uma maneira mais branda, atinge.

Porque basta você querer conviver com um fumante quando ele não pode fumar. Ele se torna insuportável. Aquilo realmente faz falta pra ele. E ele fica numa irritabilidade muito grande.

Embora eu acho que é assim ,é uma droga que a sociedade tolera assim como tolera também o álcool, porque não deixa de ser uma droga.

As pessoas que estão em ambiente onde tem outras pessoas que fumam elas também estão sobre a ação maléfica do cigarro. Quando tem alguém fumando perto de mim eu saio. É a mesma coisa de um carburador de um carro que fica soltando fumaça à toa ou um gás tóxico que tá por aí contaminado a gente. Eu acho que é o mesmo efeito, não tenho dúvida.

Além de afetar outras pessoas, afeta o raciocínio das pessoas. Eu mesmo, se tem alguém fumando meu raciocínio já não é mais o mesmo. A questão da pele, a questão do cabelo, fuma por tudo quanto é lado.

Então é uma falta de higiene tremenda. Eu acho que principalmente quem não fuma tem o direito de cobra isso, que é lei já. Não tem a menor dúvida. É uma situação anormal você ficar fumando, cheirando fumaça dos outros. É anti-social, extremamente.

\section{IDÉIA CENTRAL C - Sim, prejudica quem tem problema respiratório.}

Ah, acredito porque eu tenho reniti alérgica e me prejudica, me incomoda bastante. O cheiro do cigarro, a fumaça.

Porque eu acho que se a fumaça fosse boa as pessoas não teriam que ficar pondo pra fora. Ela pegaria e consumiria tudo. Até a própria fumaça. Então isso incomoda bastante. Ao lado de uma pessoa que tá fumando se você tem algum problema respiratório, já começa a irritar suas narinas na hora.

Uma época eu tive esse problema de sinusite, se tivesse alguém fumando perto de mim, o nariz já começava a responder. Eu acho que a pessoa que fuma, que tem o hábito de fumar, deve fumar no seu lugar separado, não junto das pessoas. Na cidade que nós estamos praticamente todas as pessoas têm problema respiratório e a fumaça do cigarro me irrita.

Quando eu estou em ambiente limpo se chegar alguém fumando, por mais discreto que seja, eи sou a primeira pessoa que percebe. Imediatamente eu sinto alergia, minha garganta fica assim como que arranhando, incomodando.

Então afeta, com certeza. Isso é pra mim uma coisa impressionante. 


\section{IDÉIA CENTRAL D - Sim, o professor fumante dá mau exemplo.}

Acredito. Eu sou bem tradicional, por exemplo: o aluno faz o que o professor faz, e muitos me pedem pra sair pra fumar.

Adolescente, de 12 a 19 anos não pode fumar. Então ele diz: como a professora fulana de tal sai pra fumar? Entendeu?

E aí, eu acho péssimo quando na sala dos professores, que eu considero extremamente negativo, um professor fuma.

\section{IDÉIA CENTRAL E - Sim, a saúde e o cheiro.}

Afeta. De alguma maneira afeta.

Ou saúde, ou cheiro que fica na roupa. Aquela fumaça traz outras substâncias que entra no corpo da pessoa, que faz mal do mesmo jeito da pessoa que tá fumando.

Quando eu tô com um pessoal que fuma e, pode ser tarde da noite, eu chego em casa tenho que tomar banho senão eu não consigo dormir.

$O$ cigarro se fosse bom, todos aderiam, deveriam aderir e acho que as pessoas que fumam acabam ficando assim meio que de lado. Eu falo por mim, né?

Eu acabo ficando bem longe. Eu não gosto nem do cheiro.

\section{IDÉIA CENTRAL F - Sim, o filho de fumante tem problema.}

Ah, com certeza. Filhos de mães fumantes têm sérios problemas. Só pelo fato de nascer de uma mãe fumante. O cigarro afeta muitos, principalmente a gestante.

E a gente vê muito. Muitas mulheres gestantes fumando e isso prejudica demais o feto. Ou a mãe que fuma e tá sempre com o filho no colo. Querendo ou não, de uma forma ou de outra, tá sempre afetando.

\section{IDÉIA CENTRAL G - Sim, sei porque fumo.}

Eu acredito que sim. Tanto que eu procuro fumar sempre em lugar aberto, nunca fumo em sala, que nem a sala dos professores aqui.

Na minha casa eu nunca fumo em ambiente que estão as outras pessoas. Eu fumo no quintal, mas eu não consigo parar de fumar. Eu já tentei, mas não consigo.

Eu acredito que afeta outras pessoas, todos os seres vivos que estão no entorno. Até aquela plantinha que está ali como as outras pessoas. Isso incomoda porque pra quem fuma também é um tanto constrangedor. A gente fica um meio sem graça de tá buscando locais onde não incomode outras pessoas. Sem... não muito a vontade também principalmente quando elas externam isso.

- Não da pra tá fumando aqui, né...

Então, ou contém a vontade, o desejo, já que o outro não fuma, ou vê outro momento, ou sai do local para não estar atrapalhando tanto. 
Se eu entro num lugar que eu não fumo e alguém tá fumando eu sinto. Às vezes eu fico até incomodada, mesmo fumando. Então eu sei, eu sou consciente disso. Incomoda porque incomoda inclusive meus filhos.

Ao compor a terceira pergunta: "E o aluno fumante, como é isto para você?", a pesquisadora procurou investigar a aceitação do professor e a atitude a ela associada quanto ao hábito de fumar cigarros dentro da escola.

A Tabela 6 e a Figura 11 explicitam as porcentagens de respostas obtidas a partir da pergunta: "E o aluno fumante, como é isto para você?", para cada Idéia Central categorizada.

Tabela 6: Numero e proporção (\%) de respostas dadas pelos professores de acordo com as Idéias Centrais" da pergunta "E o aluno fumante, como é isto para você?". São Paulo, 2006.

\begin{tabular}{lcc}
\multicolumn{1}{c}{ Idéias Centrais } & No & \% $^{* *}$ \\
\hline Eu alerto porque sou fumante & 2 & 5 \\
Não permito que fume & 2 & 5 \\
Oriento porque é um prejuízo para ele & 9 & 23 \\
Alerto, mas cada um escolhe seu caminho & 6 & 15 \\
É “coisa” de adolescente & 15 & 38 \\
Já vem de casa & 4 & 10 \\
É difícil conscientizar & 2 & 5 \\
Não me incomoda & 2 & 5 \\
Problema pequeno em relação a outros & 4 & 10 \\
Não combina com Educação Física & 1 & 3 \\
Não posso falar porque sou fumante & 1 & 3 \\
Não vi nenhum & 2 & 5 \\
Deixo sair para fumar & 2 & 5 \\
Problema sério em relação à saúde & 2 & 5 \\
\hline \multicolumn{2}{c}{ Total } & 54
\end{tabular}

*possibilidade de mais de uma Idéia Central por indivíduo.

** calculada em relação ao total de professores. 
FIGURA 11: Proporção $(\%)^{*}$ de respostas dadas pelos professores de acordo com as Idéias Centrais da pergunta "E o aluno fumante, como é isto para você?". São Paulo, 2006.

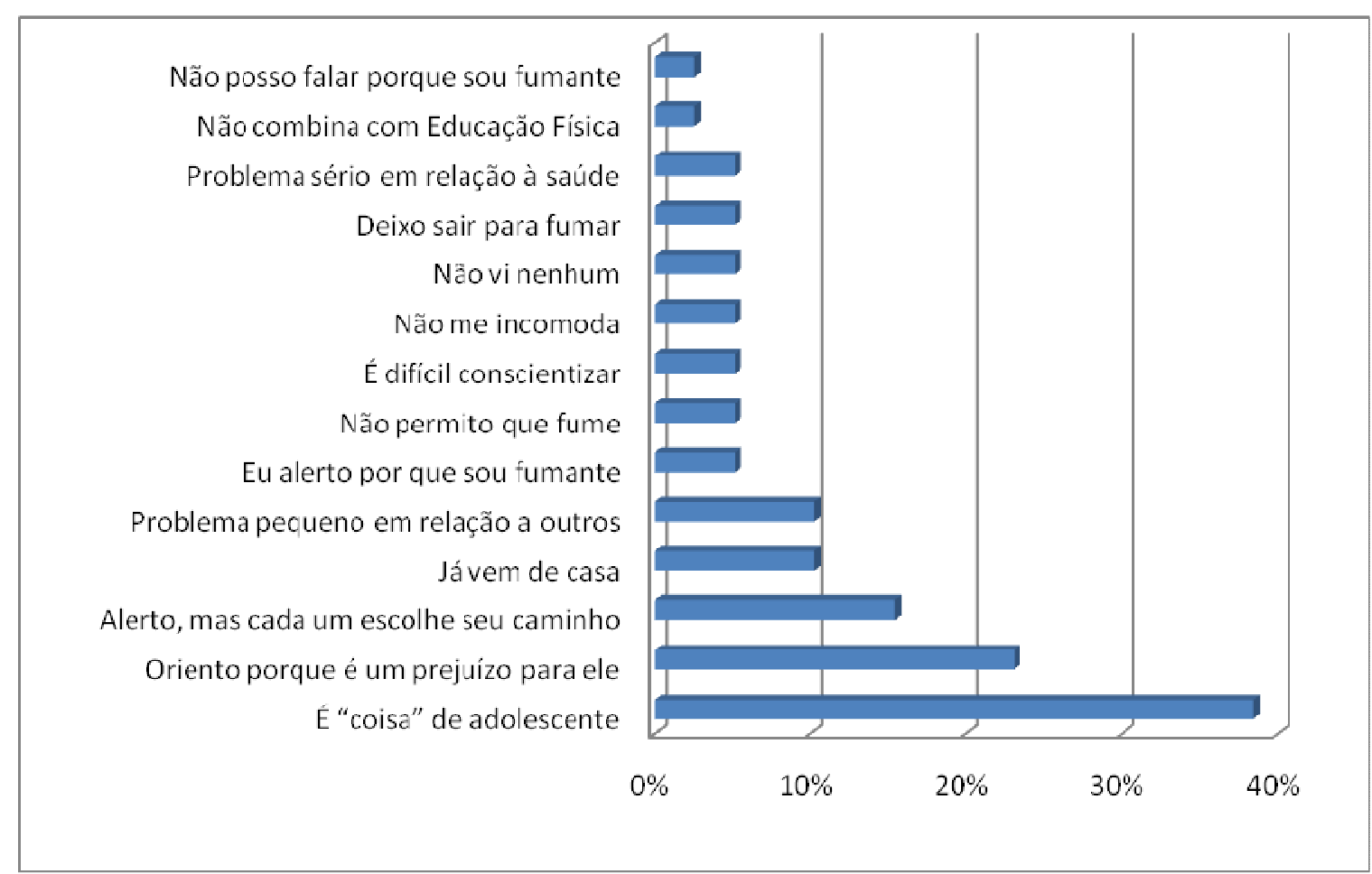

*calculada pelo número total de professores.

DSC obtidos a partir da pergunta 3: "E o aluno fumante, como é isto para você?"”

\section{IDÉIA CENTRAL A - Eu alerto porque sou fumante.}

- Ó, como eu sou fumante, o aluno fumante pra mim me preocupa bastante. Porque os fumantes normalmente são aqueles adolescentes no nível de 14, 15 anos de idade.

Então me preocupa bastante, inclusive eu comento com eles: olha, eu sou fumante e não é nada agradável. Depois que você entrou no vício é muito complicado você sair dele. Então, cara, reflete, é isso mesmo que você quer? Pra quê? Não vai resolver seu problema. 
Então não é porque eu fumo que... Eu alerto as pessoas sim, eu acho importante. E, eu não dou o exemplo, não fumo nos corredores.

Ontem, inclusive, um viu e disse: - O senhor fuma?

Porque a aluna foi à sala dos professores e eu tava fumando. Então eu falei: Não, eu fumo de vez em quando.

Mas o aluno, seria bom que não fumasse, né? Porque, dependendo da idade, fase de crescimento, né? A gente faz o trabalho para que eles não fumem.

Eu acho triste, acho muito triste porque se hoje eu tenho esse prazer adquirido numa época da adolescência, eu não concordo até. Na realidade eu também não concordo.

\section{IDÉIA CENTRAL B - Não permito que fume.}

- Olha, o aluno fumante... Eu não tenho contato com aluno dentro da sala de aula porque eles não fumam durante as aulas. Eu não permito que fume dentro da sala de aula.

Então, o que eu percebo, principalmente no noturno, né? $O$ aluno entre um intervalo e outro, ele precisa fumar. Porque é uma ansiedade dele, ele acha que ele não

pode. É proibido, então, ele acha que tem a necessidade de fumar. Ele precisa sair daquilo.

Então, eu acho que é uma falta de controle dele. O que é bem desagradável.

\section{IDÉIA CENTRAL C- Oriento porque é um prejuízo para ele.}

Bom, aqui pelo menos não tenho nenhum aluno que fuma. Na outra escola eu tenho. E sempre eu falo, desde que eu sou professora, eu aconselho.

Que pode causar câncer ou problema no pulmão.

A gente orienta. Fazemos sempre palestras, trabalhos como drogas, que é pra não fumar. Brinco com eles. Fumar dá câncer, fumar da impotência, fumar dá outras doenças, né? Pra vê se...

$E$ as mulheres precisam se conscientizar ainda mais. Então, por exemplo, mulheres vão ter comprometimento da pele, os homens também. Na menopausa vai ter perda de cálcio muito mais rápido do que o homem. Na fertilidade, na questão cardiovascular, fica tudo comprometido. Isso aí na questão da meia idade é muito terrivel, com certeza.

- Olha, você vai viver bem menos do que eu, porque eu não sou fumante.

Não faço assim sermão, mas eu não passo assim como se nada tivesse acontecido perto de mim.

- Ah, é muito triste porque ele é jovem. Eu acho que seria um prejuízo pra eles, pra saúde deles. Ele não sabe disso, não tem a noção de como é perigoso pra saúde dele quando ele chegar na nossa idade.

Então, a gente fica triste. E assim, quando eu percebo que o aluno é uma pessoa que dá pra conversar, que vai ouvir, não vai se ressentir, eu procuro conversar, eu 
procuro explicar, né? Mostrar que têm outras coisas que ele pode fazer do que fumar, né?

Só que é complicada essa idade deles. Então é essa postura que a gente tem que trabalhar. E é difícil eles mudarem porque parece que eles sentem segurança naquilo. Fumar é alguma coisa que prende, é auto-afirmação. Eu vejo muito isso no cigarro.

\section{IDÉIA CENTRAL D - Alerto, mas cada um escolhe seu caminho.}

Eu acho muito pessoal. Acho que cada um escolhe o caminho que ele quer. O aluno sendo maior de idade eu acho que ele já é dono do seu caminho. Alertar a gente alerta, mas se ele acha legal pra aparecer pros outros.

Assim, eu falo pelo seguinte. Eu não fumo, não concordo, mas se você quiser fumar pode fumar, mas não na dependência da escola, não é legal. Tem o vício dele até na rua, na casa dele, entendeu?

Porque aqui eu já dou exemplo. Eu acho que cada um tem que ter a sua responsabilidade. Se ele acha que fumar faz bem pra ele, quem sou eu pra impedi-lo, né?

Eu oriento, peço, faço algumas brincadeiras. Falo: - Ah, que coisa feia! Você fumando! Você é tão novinho, isso faz mal.

Conscientizo pra que ele não fume, mas eu não posso falar: - Você não fume mais.

A gente tenta como pode e fica na consciência do aluno. E, em escola, geralmente não se pode fumar. Então, naturalmente eu nunca entro com aluno, falando assim da minha experiência, eu nunca encontro com aluno fumando na escola.

Se tá em sala de aula, a gente procura falar, procura orientar porque se há regras, tem que ser seguida mas, geralmente essa meninada tá gostando de fumar. Virou moda, né? Pra eles é como se fosse importante, a meninada de 15, 16 anos fuma como se fosse bonito. Faz parte da turminha deles, né? Mas eu sou contra mesmo, o aluno menor eu não concordo com o fumo.

Acho que isso vem da educação mesmo. De orientação. Porque é um, é um vício como outro que te causa dependência.

\section{IDÉIA CENTRAL E - É “coisa” de adolescente.}

Em relação ao aluno eu vejo uma fragilidade mesmo, embalo pra ser aceito no grupo porque é tentado por outro colega. Ele quer fazer parte. Pra se auto-afirmar em alguns momentos, ele quer mostrar uma espécie de poder também. Principalmente na figura masculina. Se acha menos homem ou menos menina, menos mulher se não aceitar a fumar a aprender a tragar.

$E$ É isso aí. O vício começa justamente na adolescência, que é uma fase onde eles estão a todo momento querendo se auto-afirmar. Querendo se posicionar como adultos, antes, né? Antes mesmo de se tornarem adultos.

Muitas pessoas que eu conheço tiveram iniciação aí, na adolescência. Eu acho que aqui é a maior incidência do início do fumo, é na adolescência mesmo. 
Como adolescente eu entendo, é curiosidade, o cara quer transgredir regras. Ele muitas vezes ele fuma pra aparecer e, sobretudo, porque isso é aceito na sociedade como sendo bonito. Como sendo atraente. É mais pra ostentar, é a fase que ele tá querendo se aparece pra arrumar um namorico ou coisa parecida.

Então você já sente o cheiro, mas é aí é o que eu falo, acho que por falta de auto-afirmação, por falta de um objetivo, por falta de sei lá, de alguma coisa mais atrativa pra fazer. Por falta de orientar pra praticar um esporte ou trabalho.

É um pecado porque é um vício que começou e não termina. E chega aquela certa hora o organismo vai pedir como pede um almoço, como pede um jantar. Todo vício é muito fácil de adquirir, mas pra deixar é complicado.

É aquela fase de rebeldia, então eu fumo que é pra agredir meus pais. Eu fumo que é pra mostrar, principalmente pra se esconder no banheiro pra fumar, ou é afirmação deles. Vê no cigarro como uma moda. Uma modinha, né?

Vê o pai fumando, o colega fumando, ele vai falar: Ah, todo mundo fumando, né? Por que eu não posso fumar também?

Ah, é complicado. Porque eles não sabem o prejuízo que isso tá causando na saúde dele. Porque eles são muito novos, não têm uma formação adequada ainda.

O jovem, o adolescente, consequentemente nosso aluno, ele não tem muita visão assim a longo prazo. Então aquilo faz mal, ah, não faz mal agora, não sinto nada agora, então não tem problema. As conseqüiências vão vir mais pra frente. E o adolescente, ele tem problema de pensar no futuro. Ele é imediatista geralmente, né?

Eu acho que as pessoas também fumam porque acham charme. Fumando quer ser charmoso, elegante, entendeu?

Você pode ser charmoso, elegante também sem fumar. Não é o cigarro que deixa a pessoa mais elegante. Ele é aquela coisa, a tábua. Ele é a ponte, uma ajuda psicológica, mas isso aí tá em você.

Então eu acho que isso e prejudicial. Eles não têm consciência quanto isso vai fazer mal pra eles na vida futura.

\section{IDÉIA CENTRAL F - Já vem de casa.}

O aluno fumante eu acredito que ele normalmente traz essa bagagem de casa né? Porque numa casa onde ninguém fuma a probabilidade de você, do filho não fumar é maior do que numa casa onde existe fumante.

Dar conselho, nós como educadores, damos conselho tudo, mas infelizmente já vem de casa.

Agora se os pais sabem e autorizam, se dão dinheiro para comprar o cigarro, isso aí é responsabilidade deles.

Então, é complicado isso. Você já vê quem da orientação em casa. Se o pai fuma, a mãe fuma, não tem nem o que falar.

\section{IDÉIA CENTRAL G - É difícil conscientizar.}

Bom, ele fuma, né? É, nunca aconteceu de uma aluno acender um cigarro na minha aula. A gente até vê uma coisa ou outra, uma movimentação no espaço da escola. 
É que é muito difícil você fazer a conscientização eu acho. Porque se esbarra numa série de coisas, no aspecto inclusive de eles não acharem que você... eles te relacionam como uma coisa mais brega, de ta dando lição de moral.

Mas, eu pra mim, vamos dizer assim, quando eu vejo o aluno fumante eu tento falar com ele, mas também não fico insistindo muito não, ta? Porque às vezes ele fuma pra ser agressivo mesmo, né. Mas é um idiota, só isso. É um sinal de idiotice.

\section{IDÉIA CENTRAL H- Não me incomoda.} prasi.

Eu acho que é uma opção dele uma opção da pessoa. Cada um sabe o que é bom

Mesmo que você diga todos os malefícios do cigarro, se ela não se incomoda com aquilo. Incômodo pra mim, que tenho alergia as estas coisas, mas se ele se sente bem não me afeta.

Na realidade, pro todo, o aluno fumante é ruim pro ambiente que ele está. Pra ele mesmo. E mais, pra mim mesmo, como professora, isso aí não me afeta porque normalmente eles não fumam em sala de aula. E quando a gente conversa, eles passam a respeitar mais, ter um cuidado maior com o cigarro.

Eu acho que é uma coisa muito ruim, principalmente pro aluno que é muito jovem. Em geral são jovens. E a gente sabe o que o fumo causa. Uma série de conseqüências que levam até a morte, né?

\section{IDÉIA CENTRAL I- Problema pequeno em relação a outros.} temos.

É, eu acho que é um problema pequeno perto de outros problemas que nós

Ah, hoje fica difícil falar só do cigarro, porque eu tenho outras grandes preocupações. Se tivesse que colocar pra você com relação às drogas em geral, o cigarro é o que menos me preocupa. O fumar deles não é só cigarro.

É muito triste porque a gente sabe que começa no cigarro, hoje em dia e daí a pouco vai... ta querendo uma coisa mais forte.

Aqui a gente já tem histórias de alunos que já tiveram um final triste devido a isto, começaram lá no cigarro e aí depois é um baseado, depois é um pozinho e depois é uma pedrinha e aí acaba não muito bem. Quer dizer, muito ruim. É uma pena, mas em fim.

\section{IDÉIA CENTRAL J- Não combina com Educação Física.}

Ah, nem me fala. Principalmente na aula de Educação Física. Olha, a gente vê os alunos. Eles param de falar, eles têm pouca resistência, ficam tossindo, tem assim posturas diferentes, tem mais agressividade que eu falo não é só postura corporal não, é postura de respeito de tomar decisão. Tudo diferente. Porque, eles se apóiam no fumar, eles se apóiam no ídolo deles que é agressivo. 
E o cigarro eu vejo bem assim, com atividade física não combina. Não combina mesmo, e a gente sente que eles têm um problema muito sério pra acompanhar a atividade, porque sua capacidade respiratória fica diminuída e comprometida. Então não tem jeito. Alguns, a gente percebe assim que ele fuma, ele faz questão de falar isso pra mim:

- Pra fumante, né professora? É difícil.

Então eu falo: - Para de fumar.

Então ele não tem consciência, se aquilo não é bom, porque eu vou continuar fazendo?

\section{IDÉIA CENTRAL K- Não posso falar porque sou fumante.}

Então, o aluno fumante. Eu vejo assim. Como eu fumo né? Então é como se estivesse... vamos pegar uma campanha na sala de aula que eu pudesse estar falando sobre o parar de fumar. Sobre a proibição. Eu não me sinto a vontade de ta falando. Mesmo porque eu fumo.

Em alguns momentos, se o aluno fora me ver fumando então vai achar que a minha fala não ta só associada a minha prática. Eu acho que tem até certa coerência nesse sentido.

Eu vou chegar e falar pra ele, você não fuma, enquanto que eu fumo.

Nós sabemos que é prejudicial, que traz, é (pausa) os malefícios para a saúde, financeiros, sociais. Difícil agente falar pro outro né?

Não tenho este direito. A não ser que seja uma coisa que eu também esteja envolvido e que haja essa conscientização.

E alguns até são conscientes. Eles que sabem né? Mentalmente sabem quais espaços, em quais momentos devem fumar, ou podem fumar. E eu vejo isso com uns alunos principalmente no noturno.

Fala:- Olha... Não fumar né? Eu acho que isso é mais prejudicial. Porque tem os efeitos psíquicos. Até que grau a pessoa pode ta parando assim de fumar?

Enfim, acho que não é muito fácil não. Acho que... não me sentiria muito a vontade não.

\section{IDÉIA CENTRAL L- Não vi nenhum.}

Eu ainda não me deparei com aluno fumante. Tenho 8 anos de escola e, não me deparei assim em sala de aula. Se eles fumam ai fora, nunca, nunca me deparei com nenhum.

Eu nem vejo por aqui. Aqui, e tão proibido que a gente... dizem que na parte de noite, EJA tem muita aula, ai tem aluno fumante, mas eles nunca fumaram na minha frente. E sempre no pátio, longe né? Agora, minha opinião, sei lá, ele ta afetando a saúde dele né? 


\section{IDÉIA CENTRAL M- Deixo sair para fumar.}

Atrapalha, porque o vício, eu vejo assim, que muitas vezes você percebe que ele tem aquela necessidade de fumar. Você tem que liberar o aluno pra sair da sala de aula ir pra algum lugar pra ele poder fumar. Mesmo não sendo permitido na escola, a gente sabe que no período noturno, você trabalha com EJA, você trabalha com adulto.

Você não tem como podar isso, então você tem que saber administrar essa situação. Sem fumar, ele fica inquieto, não consegue prestar atenção na aula, o rendimento também, não adianta em nada.

O aluno fumante, ele é, sem o mérito da questão da saúde, ele é um aluno extremamente ansioso. Segundo, continua perturbando a aula porque vai passando o tempo ele vai pedindo, vai passando ele vai pedindo, então você tem que liberar.

Pra ele também é prejudicial porque ele vai perder a aula só pra poder sair pra satisfazer o vício dele e depois voltar. Atrapalha bastante.

$O$ aluno fumante, eu diria que se ele fosse só aluno já era muito bom (risada) o fumante atrapalha muito. Ele vem cheirando pra sala, um cheiro! E a gente sabe o que ele acabou fazendo no banheiro.

- Lavou as mãos, fulano?

-Ah, professora não precisa, vou fumar outro daqui a pouco.

Apesar de ter nas escolas plaquinhas "Não fume". "É proibido fumar", lei num sei quanto. Eles não observam não. Aquela letra é como se não existisse como todas as letras que você implementa assim uma conscientização prévia, eles não lêem.

\section{IDÉIA CENTRAL N - Problema sério em relação à saúde.}

Eu não vejo necessidade no fumar, tem outros modos de você resolver seus problemas. Entendeu? Outros modos mais saudáveis. Dialogando, conversando, procurando algum, procurando alguma ajuda. Não é fugindo pro cigarro.

Mas com relação a saúde é quando a gente fala de indivíduo e de qualidade de vida, aí a gente vê que o problema é sério.

É um problema que cada um devia estar mais atento com seu próprio corpo e eu acho que a gente ta caminhando pra isso, mas ainda assim vai ter muito chão pela frente pra gente pensar no corpo da gente com mais respeito. Eu acho que aí começou um manifesto em prol do corpo mais sadio, mas eu acho que ainda ta demorando pra gente realmente concretizar a coisa.

Ao formular a quarta pergunta: "Você já participou de alguma atividade ligada ao tabagismo na escola? Fale um pouco sobre isso", a pesquisadora procurou investigar a presença de ações ligadas ao tabagismo na escola, durante os últimos anos.

A tabela 7 e a figura 12 explicitam as porcentagens de respostas obtidas a partir a partir da pergunta: "Você já participou de alguma atividade ligada ao tabagismo na escola? Fale um pouco sobre isso", para cada idéia central categorizada. 
Tabela 7: Número e proporção (\%) de respostas dadas pelos professores de acordo com as Idéias Centrais da pergunta "Você já participou de alguma atividade ligada ao tabagismo na escola? Fale um pouco sobre isso". São Paulo, 2006.

\begin{tabular}{lcr}
\hline Idéias Centrais & $\mathbf{n} \mathbf{o}$ & \% \\
\hline & & \\
Não & 24 & 62 \\
Sim & 10 & 26 \\
Não, mas fiz conscientização. & 2 & 5 \\
Não, mas sei de algumas campanhas. & 2 & 5 \\
Não, mas gostaria de fazer. & 1 & 3 \\
\hline \multicolumn{1}{c}{ Total } & $\mathbf{3 9}$ & $\mathbf{1 0 0}$ \\
\hline
\end{tabular}

FIGURA 12: Proporção (\%) de respostas dadas pelos professores de acordo com as Idéias Centrais da pergunta "Você já participou de alguma atividade ligada ao tabagismo na escola? Fale um pouco sobre isso". São Paulo, 2006.

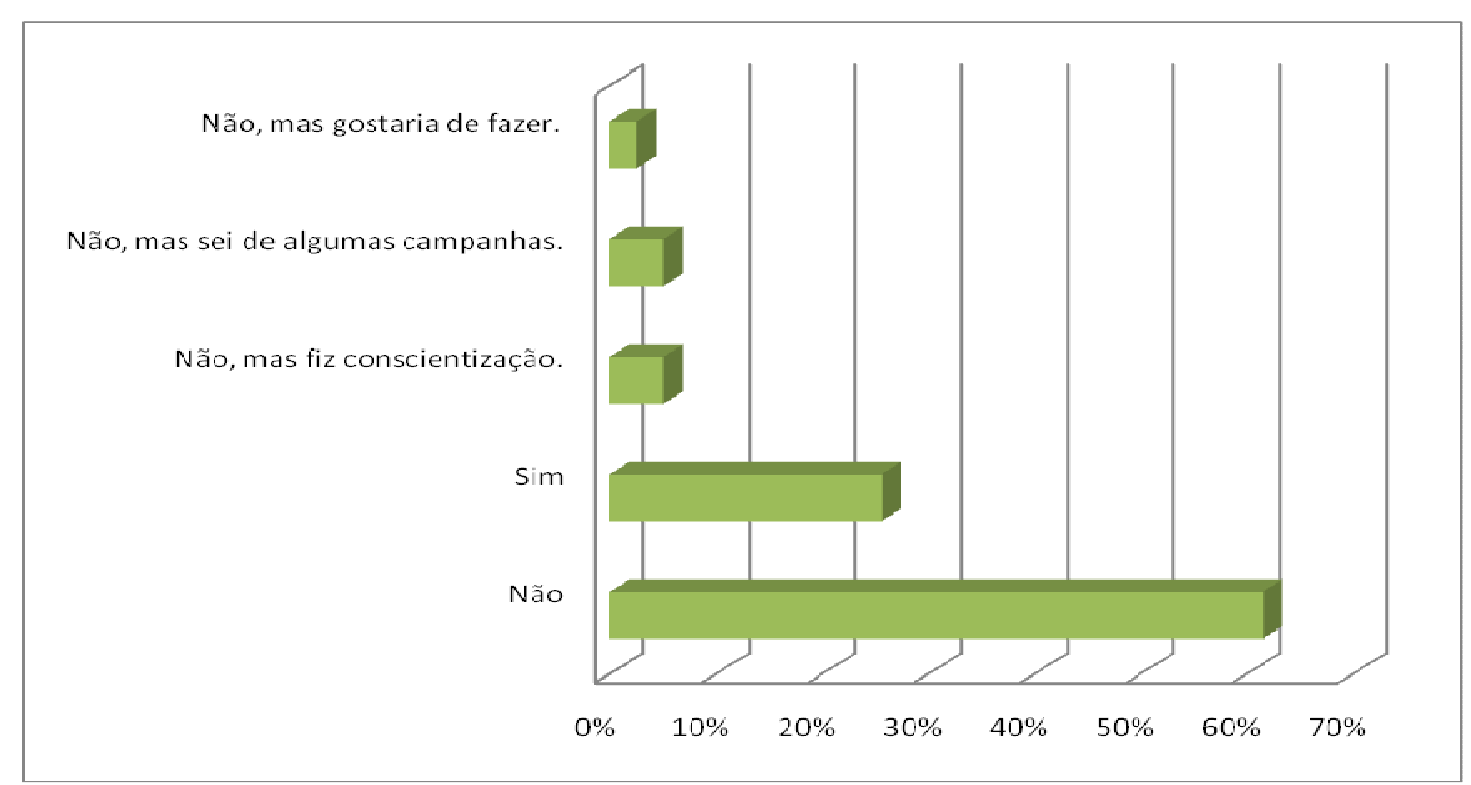




\section{DSC obtidos a partir da pergunta 4: "Você já participou de alguma} atividade ligada ao tabagismo na escola? Fale um pouco sobre isso".

\section{IDÉIA CENTRAL A - Não.}

Não, não. Já comentamos assim, fiz comentários, mas trabalho mesmo ou projeto não. De prevenção, não tive essa oportunidade. Nem em outra escola. Nenhuma escola aconteceu qualquer coisa, qualquer projeto, qualquer palestra.

Às vezes você bate no preconceito dos pais que não admitem este tipo de diálogo de comportamento e fica muito complicado você sozinho tentar fazer.

A não ser que surja um projeto na escola que você, como se diz, você tenha respaldo da Diretoria de Ensino, da Secretaria de Educação, que possa te fornecer material.

Existem campanhas de prevenção, né? Mas nunca trabalhei com pessoa nem do tabagismo, nem das drogas. Eu fiz mais de DST, mas não tem como deixar de falar nisso. Sempre a gente acaba falando.

\section{IDÉIA CENTRAL B-Sim.}

Em outra instituição já. Com cartazes, exposição de trabalhos com o aluno, demonstrando o que pode acontecer com ela no futuro.

Já trabalhei com alunos fazendo campanhas, fizemos debates na sala de aula.

Já trabalhei com palestras. Tiveram enfermeiros, médicos e foi falando como ele age no pulmão.

As crianças ficaram bem interessadas, se envolvendo muito com o que ele estava falando.

Já fiz um trabalho de conscientização dos malefícios, sobre o cigarro, né? Pros fumantes e pros não fumantes que convivem com os que fumam e teve gente que veio, avisou que parou de fuma. voltando.

Outros ficaram apavorados, mas dali a pouco o vício falou mais alto e acabaram

Aqui nesta escola, o que a gente observou é que não é um dos problemas mais gritantes, acho que pela proibição nas escolas e como hoje já liberou até certo ponto. Eles estão a procura de coisas assim até piores.

Na minha época acho que já foi mais é, procurado, né? Experimentar o cigarro eu acho que era uma curiosidade maior antigamente, agora eu acho que tantas outras coisas já surgiram que o cigarro ficou ultrapassado, fora de moda.

Olha, eu lembro que na época, quando tinha educação moral, a gente falava muito sobre vícios. E aí a gente falava todos os tipos de vícios, inclusive o fumo. Depois 
essa matéria acabou, saiu do currículo, mas eu às vezes falo sobre violência e aí eu falo sobre os vícios, que acaba acarretando até uma certa violência e aí eu já entro um pouquinho no cigarro.

Uma vez na escola pública, no noturno, nós fizemos um trabalho, acho que era uma coisa assim, Semana da Saúde, e no HTPC, foram feitos sorteios, né? Cada professor tinha que falar de um assunto, para não massificar a situação e ficar uma coisa maçante pro aluno, cada um pegou um assunto diferente. E o meu foi é, um foi o tabagismo e a outra foi sobre gravidez na adolescência.

Aqui nos tivemos atividades né? Um projeto que é do INCOR e, vamos dizer assim, de todas as atividades que a gente fez que seria o álcool, a alimentação e o fumo é, a gente mostrou algumas experiências pra eles ficarem conscientes do problema que o cigarro causa .

\section{IDÉIA CENTRAL C- Não, mas fiz conscientização.}

Não. Eu andava com uns botonszinhos, não sei se era do INCOR uma época, fazendo propaganda, mas por conta própria. Não da escola.

Fizemos uma campanha assim, mas foi informal. Não foi um trabalho realmente feito. A única coisa que a gente fez foi assim a conscientização que não deve fumar.

\section{IDÉIA CENTRAL D- Não, mas sei de algumas campanhas.}

Não. É assim, eu já fiquei sabendo de algumas campanhas é, sempre tem campanhas não só na escola mas na comunidade, em televisão tem aquele dia antitabaco, que eles fazem uma vez por ano, mas eu não participei porque eu não sou fumante.

Na escola, não.

Ah, voltando um pouquinho que agora eu me lembro, é, tem alguns trabalhos que alguns alunos apresentam falando assim da questão dos efeitos das drogas em geral. O cigarro é outra forma citada. Aqui mesmo no ano passado teve, mas era uma atividade que eles abordavam isso, traziam à tona essa questão do cigarro.

\section{IDÉIA CENTRAL E- Não, mas gostaria de fazer.}

Ainda não participei, mas eu teria vontade de participar com os professores, com os próprios alunos, conscientizando sobre o tabagismo.

O que ele pode acarretar na pessoa que fuma. Quais as conseqüências também que trazem isso, o fumo pra ele. Como ele poderia parar de fumar.

Eu sei que isso não é possível, fazer a cabeça de uma pessoa assim, mas eu acho legal trabalhar o tabagismo pra alertar o mal que o cigarro ta trazendo pra ele. Este seria um trabalho interessante que eu gostaria de estar fazendo.

Com a pergunta 5: "Como poderia ser abordada a questão do tabagismo pelas escolas?", a pesquisadora procurou abrir um espaço para a reflexão e intervenção 
espontânea do professor sobre o tema na escola, utilizando seu repertório de experiências em sala de aula.

A Tabela 8 e a Figura 13 explicitam a porcentagem de respostas obtidas a partir da pergunta: “Como poderia ser abordada a questão do tabagismo pelas escolas?”, para cada Idéia Central categorizada.

Tabela 8: Número e proporção (\%) de respostas dadas pelos professores de acordo com as Idéias Centrais" da pergunta "Como poderia ser abordada a questão do tabagismo pelas escolas?". São Paulo, 2006.

\begin{tabular}{lcc}
\hline Idéias centrais & No & \% $^{* *}$ \\
\hline Alertando a respeito dos prejuízos e qualidade de vida. & 17 & 44 \\
Com trabalhos feitos com os alunos. & 10 & 26 \\
Em forma de projeto na escola. & 4 & 10 \\
De forma diferente. & 5 & 13 \\
Com proibição e punição. & 2 & 5 \\
Não sei como. & 5 & 13 \\
Depende da escola. & 1 & 3 \\
Começar pela mídia. & 1 & 3 \\
Através de conscientização junto aos pais. & 2 & 5 \\
\hline total & 47 & \\
\hline *possibilidade de mais de uma Idéia Central por indivíduo. & \multicolumn{3}{l}{} \\
**calculada em relação ao total de professores. & \multicolumn{3}{l}{}
\end{tabular}


FIGURA 13: Proporção $(\%)^{*}$ respostas dadas pelos Professores de acordo com as Idéias Centrais da pergunta "Como poderia ser abordada a questão do tabagismo pelas escolas?’. São Paulo, 2006.

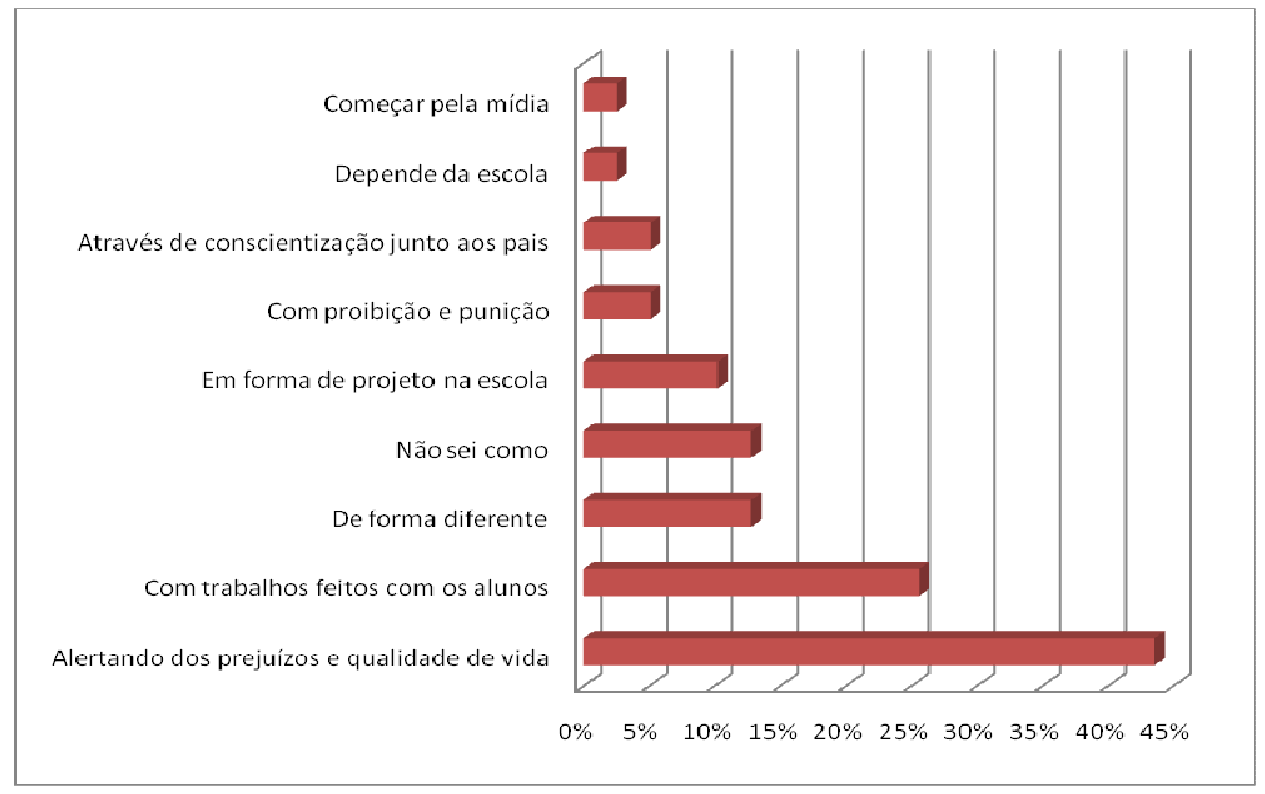

*calculada pelo número total de professores.

DSC obtidos a partir da pergunta 5: “Como poderia ser abordada a questão do tabagismo pelas escolas?"

IDÉIA CENTRAL A- Alertando a respeito dos prejuízos e qualidade de vida.

Ai que complicado! Eu acho que alertando.

Através de palestras mesmo, demonstrar através de filme como vai ficar o pulmão dele no futuro, o que pode acarretar o que pode prejudicar na vida dele. Dentro do conteúdo, no caso, ou de biologia, ou de ciências no ensino fundamental. Com naturalidade. E falar na real. Quais os perigos pra saúde, pro bolso. Eu acho que é bem por aí. Eu acho que, eles fumam bastante.

O que causa, que tipos de doenças. O que vai te fazer hoje e pro futuro. Pra você, pra sua família, pra comunidade, entendeu. Então a gente fala pro pessoal que o cigarro, ele ta prejudicando a ele e toda a comunidade, entendeu? Porque o cigarro traz problemas.

É, seria interessante passar vídeo, né? Fazer conferências. Dar palestras. Fazer realmente projeto de esclarecimento.

Porque hoje em dia é muito fácil cair nas drogas. E começa pelo cigarro. Que as pessoas entram como curiosidade, como válvula de escape pra vê e pra sair é que é difícil. 
Poderia ser abordado assim com quem tenha assim um conhecimento amplo, por especialista, viu? Porque eu acho que também pra alguém ta falando qualquer coisa não serve, como é um caso sério, o cigarro causa muitos problemas.

É claro que os professores podem estar orientando também, dentro do conhecimento deles, mas eu acho que nada seria melhor do que o especialista pra tratar dessa situação.

Porque tem muitas matérias, muitas disciplinas, no caso, que os alunos ficam meio que como que eu vou dizer, pra eles é tudo muito abstrato. Então eu acho que nesse tempo que os alunos têm de abstração em determinadas matérias é onde deveria entrar o especialista, como se fosse um psicólogo e dar aulas pra eles. Mostrar o caminho correto. Com palestras, com, testemunhos. Pegar pessoas que fumaram muito e que pararam.

Claro que a gente não vai consegui que todo mundo pare de fumar, mas acho que se eles tiverem mais consciência, acho que a grande maioria ajuda.

Eu acho que tem que ser uma coisa que chame mesmo atenção. Eu sou bem a favor das propagandas que ta sendo divulgada na televisão. A gente fala, a pessoa sabe que faz mal, mas não tem aquela consciência.

Acho que tinha que ser uma coisa, como estão falando nos comerciais, mostrando aquela coisa que choca, um feto, a pessoa que ta grávida interrompe uma gravidez ou ataque de pulmão, edema pulmonar. Eu acho que tem que ser uma coisa que causa impacto mesmo. Pra pessoa ter consciência do que é o tabagismo. Porque senão a meninada não tem muita consciência, e vão atrás dos pais também.

Geralmente os pais fumantes têm os filhos que fumam também. Então, palestras e essas palestras seriam levadas aos familiares, ao conjunto dos funcionários, e também a escola como um todo.

Eu acho que de qualquer maneira a gente teria que dar. Eu acho que é função da escola também ta levando isso pro aluno; quer dizer, mostrando pro aluno que o cigarro é uma coisa muito prejudicial. Não é brincadeira mesmo.

\section{IDÉIA CENTRAL B- Com trabalhos feitos com os alunos.}

Os professores já abordam. Os professores de outras disciplinas até fazem um trabalho interdisciplinar, aonde eles abordam e trabalham em cima disso com cartazes, fazem seminários. Esse trabalho já existe.

Acho que através de pesquisas, que pesquisassem sobre o assunto. Sobre os males, o porquê da necessidade de eles estarem fumando, experimentando. $O$ que os leva a isso. Fazendo conscientização.

Eu acho que a partir do momento que eles tomarem consciência de que é muito fácil iniciar e muito difícil parar, então talvez eles tenham uma preocupação um pouco maior em não experimentar.

É bem complicado e com todo esse processo de propaganda que está se fazendo dá para trabalhar acho que multidisciplinarmente.

Dá pra trabalhar matemática, ciências, mais até nestas duas partes, mas eu ainda sinto falta de material pra trabalhar, porque às vezes eu vejo uns cartazes muito legais. 
Inclusive tem um que tem todas as substâncias que tem no cigarro, mas é de difícil acesso. Não sei se tem disponível por aí, não sei se também tem toda uma jogada das grandes marcas que eles não querem que seja mesmo visto, falta um pouco mais desse aprofundamento de substância, do mal que pode fazer pro indivíduo.

Dizem assim, só o professor de ciências deveria fazer isso por uma questão de se relacionar com a saúde. Eu não acho assim, eu acho que todos os professores deveriam se unir e fazer campanhas, fazer trabalhos, falando, tudo assim, o que pode ser bom e o que pode ser ruim. Acredito que tudo na vida tem o lado bom e tem o lado ruim. E no caso do tabagismo, no caso do cigarro, tem mais coisas ruins do que coisas boas.

Então se a gente, ta certo que ali ta colocando um lado assim meio ruim do que acontece com as pessoas, mas eles tão interessados em saber o que acontece.

Então se agente coloca, dessa forma pro aluno, mesmo que seja por meio de cartazes, é que nem no meu caso, no caso do inglês, colocar frases e alguns símbolos, contra o cigarro, contra o fumo talvez desperte o não interesse deles por essa atividade, por esse vício.

O professor de história mostrar o que aconteceu com algum personagem histórico devido a isso. O professor de ciências falar com relação à saúde, a professora de português e a professora de inglês montar esses cartazes e aí trabalhar estrutura de frase, então eu acho que deveria acontecer isso. Seria uma idéia, né?

E começar no fundamental II, né? Até, se bobear no fundamental I, na $4^{a}$ série. Porque a criança, eu vejo assim, que quando você atinge um adolescente com mais idade, a partir dos 15, 16, no Médio, ele já tem consciência. Seja através da mídia, seja em casa tendo acesso a compra mesmo do cigarro, e tudo mais.

Eu vejo que a criança, quando ela é abordada muito cedo, 8, 9, 10 anos, a tendência dela de se manter no vício é muito maior, porque ele não tem uma consciência que aquilo realmente vai fazer mal. Não tem tanto discernimento, se aquilo é bom ou ruim.

Tanto é que a gente percebe que você consegue aliciar uma criança pra drogas também nessa idade. Eles chegam na $5^{a}$, querem experimentar muita coisa, aquilo que eles não poderiam fazer no fundamental I. Bobagens, tipo, ter que andar em fila, sair organizadamente da sala, coisas que o fundamental trabalha muito bem, né? E quando chega no II ele começa a testar, começa a observar o aluno de $7^{a}$ de $8^{a}$ e ele começa:

- Bom, mas eles fazem isso, então eu também posso fazer.

E ficam te testando até o meio do ano, mais ou menos, pra saber qual é o limite de cada professor. O que ele pode o que ele não pode. Então, eu acho ali que se ele é convidado a experimentar o cigarro ou qualquer coisa, é o momento que ele acaba decidindo se vai ou não.

Eu acho assim que esse trabalho que eles fizeram de uns anos pra cá de colocar aquelas fotos atrás dos maços de cigarro realmente tem surtido muito efeito. Você entra num debate, e verifica assim a oportunidade dentro de sala de aula de discutir isso, é interessante.

Discutir muito isso em sala de aula, mas de uma forma assim mais descontraída, deixar a criança fazer seminário. Eu acho que funciona muito quando eles pesquisam, quando eles vão expor aqui o que eles aprenderam eu acredito também que fixe mais. Pesquisa mesmo, a criança ir atrás. 


\section{IDÉIA CENTRAL C- Em forma de projeto na escola.}

Eu acho que em forma de projeto, né? Envolvendo todos os professores, envolvendo a coordenação tudo.

Teria que ser discutido, ser uma coisa assim pra poder trabalhar melhor com o aluno e integrado a toda a turma.

Eu acho que em forma de projeto é melhor do que só você falar em livro. No livro comenta você lê o assunto, faz algumas experiências, fica só informativo. $O$ projeto sempre é mais dinâmico, é mais longo e envolve mais.

Você conhece melhor o aluno e tem tempo de retornar pra você algumas coisas que aquelas aulas mais curtas não tem.

E durante as aulas você não precisa necessariamente falar do assunto tabagismo, porque tem alguns momentos em outras aulas que ele acaba vindo à tona, apesar de ser uma coisa assim pequenininha. Mas eu acho que vai infiltrando na cabeça, pelo menos da maioria.

Por exemplo, eu to falando um assunto sobre pele, que é um assunto que o cigarro, ele tem esse poder, tem algumas substâncias que fazem com que a pessoa aparente mais velha. A pele envelhece. Então nesses momentos você já aborda esse assunto.

Não da pra gente alcançar todo mundo, mas ajuda e aí até o vídeo não fala diretamente tabagismo, fala de outras coisas, de outras coisas que envelhecem a pele, como o sol que queima, tal. Mas aí eu fiz um resuminho do vídeo e eu coloquei do lado. Quando ele falou, a pele mostra a idade, eu coloquei tabagismo para eu comentar, então eu faço essas intervenções também.

E é assim através de projetos, todo um envolvimento eu acho da escola que vai trabalhar esse projeto. E, eu acho que é papel da escola porque é na escola que começa.

\section{IDÉIA CENTRAL D- De forma diferente.}

É, eu acho que deveria se feita de uma forma diferente do que a gente simplesmente dizer que faz mal a saúde.

Eu acho que faz parte, mas esse discurso não cola com eles. Sabe, eu acho que existe, como existe na questão das drogas, uma distância muito grande entre o discurso de prevenção que é feito e o que vai realmente ser efetivo com o jovem, né? Aquilo não vai surtir efeito nenhum. tenho.

As campanhas têm que ser um pouco diferente, pelo menos é essa imagem que eu

Eu tenho a idéia de que quando você oferece outras soluções, outras coisas mais interessantes, como a possibilidade de apreciar arte, de fazer um esporte, de ta movimentando todos eles de uma forma mais produtiva mesmo e mais gostosa, eu acho que essa curiosidade por esse cigarro, por outras coisas ficam em segundo plano.

Então, é uma coisa assim de tentar suprir alguma coisa que ta faltando. Assim como eu acho que o cigarro é distração, muitas vezes pode ser assim uma ocupação, 
pode ser substituído por uma ocupação um pouco mais inteligente uma coisa mais interessante. Então se você oferece essa distração mais interessante talvez seja um caminho.

Eu acho que cigarro é uma fuga de alguma coisa. Então vai fazer outras coisas mais legais, entendeu? Que te dá o prazer, mas que não vai te prejudicar, como as outras pessoas também.

Então se pegar isso aí pra molecada, que tem prazer na vida sem o cigarro, porque a molecada é muito ligada a prazer. Vai deixar você mais bonita, mais interessante, mais atraente, mais chamativa, eu acho que é por aí. Porque ficar falando, mostrando as conseqüências, mostrando as doenças, eu acho que já não ta fazendo mais efeito também. Já passou também a época de ta alarmando e assustando.

E não é que eu não me sinta preparada para trabalhar com projetos na escola, não tem tempo hábil pra você fazer esses tipos de projeto. Porque você se envolve com uma série de coisas, aí vem uma série de coisas que você tem que executar, de cima pra baixo, e quer dizer, de repente outra coisa que seria interessante você estar trabalhando com o aluno você não consegue.

Quer dizer, às vezes não é nem a questão do professor não estar preparado, eu até acho que o professor não está preparado pra uma série de coisas, mas o problema não é só falta de preparação. A falta de tempo, a falta de material técnico, talvez um espaço pra que seja desenvolvido algumas atividades pertinentes.

Por exemplo, no caso em geografia eu procuro trabalhar a questão econômica, a questão cultural ligada ao tabagismo, mas assim mesmo é difícil. Ou a escola ter mais oportunidade. Ter mais profissionais que pudessem desenvolver trabalhos ou esporte, fora do período da escola, mas uma coisa organizada, que o governo pensasse nisso. Porque se as pessoas não têm, naquele espaço de tempo, não tem o que fazer, ele vai procurar uma outra coisa e geralmente procura... né?

São alunos que os pais trabalham o dia inteiro, ele vive em companhia de amigo, o amigo fuma, a família do amigo fuma, o outro fuma, ele fuma também. É o convívio que ele tem. Agora se a família não fuma, ele não convive com as pessoas que fumam, ele vai acabar fugindo disso. Agora, chance pra qualquer tipo de escola, não é só estadual não.

\section{IDÉIA CENTRAL E - Com proibição e punição.}

O que eu entendi até agora é que aconselhamento não funciona. É, essas campanhas muito, vamos dizer assim, entre aspas, informativas não funciona.

Pra mim tinha que ser uma lei, assim pau, pau pedra pedra.Não pode fumar aqui, acabou e pronto. E ter alguma punição pro cara que fuma. Advertências, tinha que ser considerada uma falta disciplinar grave. Eu acho. Porque falar e aconselhar, isso aí eu nunca vi eficiência em nada.

Esclarecer. Comparo isso daí com outras medidas, por exemplo, de gravidez na juventude, uso de camisinha. Qualquer campanha que você faz nesse sentido, ela é destruída na hora do testemunhal. O sujeito ta fumando, ele vê, chega um colega perto dele, o cara oferece um cigarro, tem muito mais força do que qualquer campanha. 
Então tem que ter punição pro cara que fuma. Começando pelos professores. Professor, funcionário. Aqui houve um caso absurdo que eu achei, numa festa junina, os professores que estavam na porta atendendo os pais fumando. Com o cigarro, cinzeiro, sei lá, começa por aí.

Eu acho que o professor tinha que ser advertido, por parte da direção mesmo. Não vai fumar e pronto

É difícil. Na escola, por exemplo, existem leis proibindo fumar, restringir o máximo que puder o espaço pra quem fuma. Só que a gente viu, existe lei, em espaço público é proibido, mas a gente não consegue totalmente fechar o cerco não, é muito difícil.

As campanhas, por mais que você fale: tem que ser assim. Fala, fala e não sei. Vamos punir quem pegar fumando, medidas enérgicas, não vai fumar ali. É ser meio militarzão mesmo. Eu acho. Aqui não vai fumar e pronto. Por quê? Porque não pode, pronto acabou.

\section{IDÉIA CENTRAL F- Não sei como.}

Olha, não sei nem como vai ser abordado isso, porque existem problemas tão maiores que é a questão da cocaína, da maconha, do alcoolismo, que o tabagismo sinceramente acabou ficando meio de lado. Eu vejo dessa forma. Só o cigarro, a droga que é aceita socialmente.

Então ultrapassa um pouco até essa preocupação que nos temos com esse vício que é aceito socialmente. Não que o tabagismo não seja tão sério quanto, mas por ser permitido pela sociedade, talvez as pessoas não dêem a devida importância pra isso. Talvez estejamos até meio atordoados, anestesiados e não damos a devida importância pra isso. E, não temos como tomar providência. Não temos com quem contar, nem com direção nem com a polícia e nada a nosso favor. Estamos inseguros nesta situação.

Porque na verdade assim o vicio, você tem que tomar muito cuidado, com o que você vai falar. Como trabalhar. Porque você pode dar margem pra outras coisas, pessoas.

Tem pessoa que, você ta trabalhando uma coisa e quem ta recebendo a informação pode achar que é vantagem que é legal, não tem nada de mais. É muito complicado trabalhar o vicio em si. Incluindo o cigarro.

É uma droga lícita, que o que a mãe fala e que o pai fala nessa idade não serve. A experiência de quem é fumante não serve. É um desafio na verdade fumar, como é um desafio beber, como é um desafio fazer o que não é correto.

Eu acho sabe mais claramente assim: eu sei que se tudo fosse liberado desde que existisse uma palavrinha chamada educação, não é educação "dá licença" e "por favor", é educação de educar de aprender. Então você tem aquela linha, isso acontece isto, isto se você for por este caminho vai acontecer isto. Se você tem uma seqüência e se você quer experimentar? Tem que ser claro que o problema é seu. Inclusive na maconha.

Nunca fumei maconha não, tá? E nem conheço. Mas é um fato, só existe a maconha porque tem quem compra. Só existe cigarro porque tem que compra. Agora clarear a cabeça do adolescente é um trabalho difícil. Principalmente se for proibido. 


\section{IDÉIA CENTRAL G- Depende da escola.}

Olha, depende da escola, depende da classe. Tem escolas que se poderia falar de uma maneira mais, como se diz, aberta. Outra já de maneira mais restrita. Entendeu?

Seria de uma maneira mais e repressora. Porque depende do nível do aluno, da origem, da educação que ele teve.

\section{IDÉIA CENTRAL H- Começar pela mídia.}

Olha, começando pelos meios de comunicação, né? É que às vezes a gente vê propagandas em televisão ou outdoors, revistas. Então eu acho que a gente poderia começar a abordagem pelos meios de comunicação, pra eles observarem o que a mídia passa.

Se bem que eu acredito que isso já ta diminuindo bastante porque a gente vê que em novela os atores não fumam tanto.

\section{IDÉIA CENTRAL I- Através de conscientização junto aos pais.}

Ah, eu acredito que a escola sozinha não pode fazer nada. Se você não tiver os pais junto com você na escola pra tentar resolver a questão, conscientizando, mostrando pra eles que o exemplo deles conta muito. Pedindo pra eles observarem as crianças nessa adolescência.

Os professores também falando bastante, porque é um assunto que 50 minutos de aula, se não for tratado especificamente na aula de ciências, você não toca porque não tem tempo. Então acho que só aula de Ciências, Biologia, pra lidar com um problema que pra mim tem, além da questão do ver fazendo, tem a questão psicológica também. E eu acho que precisa ser trabalhado de forma lenta, cotidiana e conjunta. Porque só a escola não resolve nada. Porque, quem é a escola, a escola são os professores, né? O contato que a gente tem com os alunos é pouco.

Aí eu passo pra outra questão que é o que é que os professores podem tratar em sala? O que é delicado, o que não é? O que os PCN passam pra ser tratado na questão do tabagismo?

E a escola vai tratar daquele assunto por preocupação dela mesmo, problema que ocorreu ali no seu cotidiano então por isso ela quer tratar desse assunto. E que seja atingido o maior número de pessoas possiveis, mas se não for quem mais vai tratar desse assunto?

Na sexta pergunta: "E sobre projetos relacionados ao tabagismo na escola, o que você acha disto?", a pesquisadora procurou investigar a aceitação de projetos interdisciplinares como tema transversal, que, com muita freqüência, são inseridos na escola. 
A Tabela 9 e a Figura 14 explicitam a porcentagem de respostas obtidas a partir da sexta pergunta: "E sobre projetos relacionados ao tabagismo na escola, o que você acha disto?", para cada idéia central categorizada.

Tabela 9: Número e proporção (\%) de respostas dadas pelos professores de acordo com as Idéias Centrais" da pergunta "E sobre projetos relacionados ao tabagismo na escola, o que você acha disto?". São Paulo, 2006.

\begin{tabular}{lcc}
\hline Idéias Centrais & № & \% $^{* *}$ \\
\hline Acho interessante. & 25 & 64 \\
Já existe. & 1 & 3 \\
Acho válido, porém com outra linguagem. & 4 & 10 \\
Válido se envolver pais e comunidade. & 1 & 3 \\
Válido se o professor for preparado para isto. & 2 & 5 \\
Não acredito na eficiência dos projetos. & 5 & 13 \\
Não vejo necessidade. & 1 & 3 \\
Não faria porque fumo. & 1 & 3 \\
\hline total & 40 \\
\hline
\end{tabular}

*possibilidade de mais de uma Idéia Central por indivíduo.

**calculada pelo número total de professores.

FIGURA 14: Proporção $(\%)^{*}$ de respostas dadas pelos professores de acordo com as Idéias Centrais da pergunta "E sobre projetos relacionados ao tabagismo na escola, o que você acha disto?’. São Paulo, 2006.

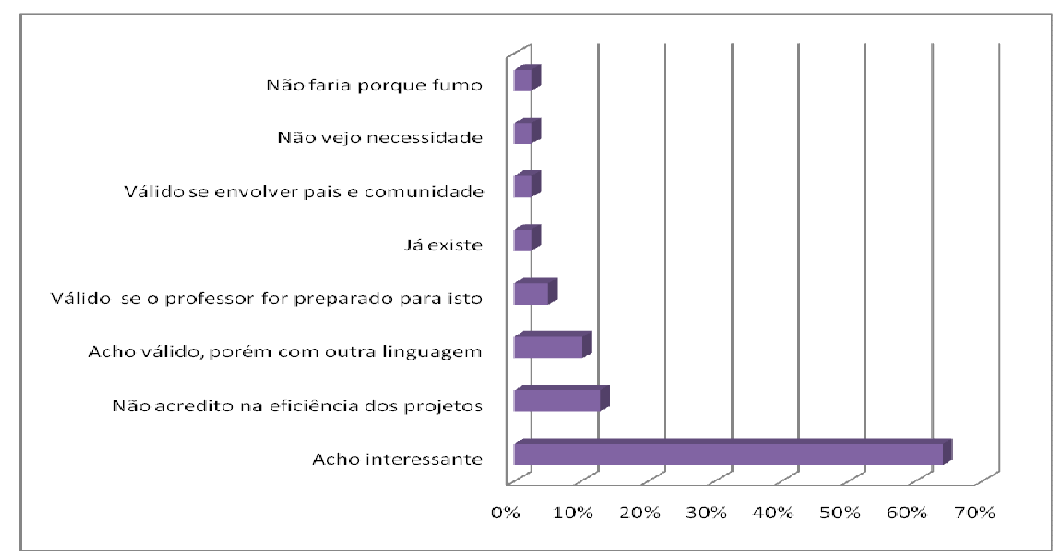

*calculada pelo número total de professores. 


\section{DSC obtidos a partir da pergunta 6: "E sobre projetos relacionados ao} tabagismo na escola, o que você acha disto?"

\section{IDÉIA CENTRAL A- Acho interessante.}

Eu acho interessante e seria benéfico. Porque o projeto, você pode desenvolver de diversas maneiras. Em forma de teatro, não é assim? Em forma de dança.

E é uma maneira de chamar a atenção no palavreado deles. Naquilo que eles gostam de fazer. Porque você coloca aí um cara falando, falando e ele escutando, não adianta você sabe que aluno não escuta mesmo.

Então eu acho legal trabalhar em projeto, tinha que ser por interdisciplinaridade, todos os professores entrarem, todas as matérias. Não só o ensino fundamental II, mas desde o pré, onde a criança teria noção do que afeta a sua saúde e para quando ele for adulto, ter noção do que ele realmente quer pra vida dele.

Pra trabalhar acho que eu teria que me aprofundar um pouco mais, ir à procura, trazer pra eles pessoas que estão no abismo mesmo pra que eles vejam essa participação.

Como é que é. Hoje eu sou jovem, eu posso tudo. Comparações. Porque eles gostam muito daquilo que eles vêem.

Então teria que levá-los pra casa de saúde, onde as pessoas estão em recuperação, ta? Um depoimento de uma pessoa que tem problema de saúde e não tinha consciência disso.

Os prejuízos, uma conscientização. Não é bom. Você mais tarde vai ter insuficiência pulmonar devido a isso. Às vezes a gente tem dados estatísticos de quantas pessoas morrem ao ano por efeito de câncer de pulmão, problemas gástricos, tudo que ta ligado ao cigarro.

A gente lida com menores, uma vez que ele põe um cigarro na boca já é um degrau pra ele ir para as drogas. Mesmo também porque o cigarro também é uma droga.

E tem que dar exemplo. Não adianta fazer um projeto e o próprio professor fumar. Aí é complicado.

E eu acho que a gente peca bastante. Deixa de falar de forma constante dentro da sala de aula. De uma maneira corriqueira, mas constante e de uma forma suave apenas, não aquela forma assim meio que de hora marcada. Um projeto então durante dois meses a gente vai estar falando sobre o assunto. Eu acho que tinha que ser uma coisa assim mais do dia- a- dia.Virar hábito.

Deixar ele fumar se ele quiser, o livre arbítrio, mas o importante é mostrar pra ele o que está acontecendo no mundo, nos outros países com as pessoas, até a parte financeira, o que ele está gastando de dinheiro, pra transformar isso em outro benefício pra ele, por que é um gasto. Um gasto que não tem volta. E estraga a saúde, os dentes.

E legal pegar uma pessoa com dentes perfeitos, bonitos, quando abre um sorrisão e a pessoa depois de 30 anos, precisando de tratamento de dente. Tudo 
amarelo, bem diferente.Tem que mostrar pra molecada como vai ficar depois. Praticamente.

O jovem tem que pegar por outro lado. $O$ apelo deles, como eles são muito visuais, você deve montar um projeto visual mesmo, esteticamente, é isso que eu quero dizer, esteticamente. Não só pra sua saúde.

O governo devia investir mais nesses projetos de saúde, né? Porque só os livros, lousa e giz não resolvem.

Agora, eu acredito que as escolas, particular, estadual, ou municipal, tem que ter durante o ano dois ou três trabalhos assim de palestra com especialistas com esses alunos e mostrando o mal que o cigarro causa, entendeu?

Porque na hora que se ta fumando, eu não acredito que seja bom, mas pra quem fuma é gostoso. Aí o fumo parece que já da vontade de estar com o álcool. Pelo menos todas as pessoas que a gente vê fumando sempre têm um copo de alguma coisa ao lado.

Os alunos precisam. Porque os professores em sala de aula por mais merecimento que tenha fica complicado. Muitas vezes a gente encontra barreiras com os próprios pais que não admitem que você dê esse tipo de conselho pros filhos. Conscientizar os pais, conscientizar os alunos.

Falam-se muito em cursos para os professores, reunião pra isso, reunião pra aquilo, não adianta. Eu acho que a base pra se educar é o aluno. O tanto de dinheiro que se investe nos cursos pra professores destina-se uma parte pra esse tipo de coisa. Eu não diria pra todas as séries, mas se você pegar aqui, por exemplo, que vai da quinta série a terceiro colegial, se vier o ano que vem um projeto desses, alguns estudantes fazer alguma coisa, um estágio aqui com as quitas séries, eu tenho certeza que na sexta eles já vão ter uma outra consciência. Aí já pode passar pro outro estágio, pro outro especialista. E por ai vai. Tenho certeza, que o caminho seria por aí.

Porque não adianta falar que tem que ter pedagogia do afeto, se a criança não sabe o que é afeto e se o professor não tem como distribuir esse afeto.

Uma pessoa que fica das sete às cinco da tarde em sala de aula, é complicado. E o que acontece é que nós estamos aí de frente com os adolescentes, e a gente percebe que eles estão se perdendo, se acabando e a gente tem muito pouco para fazer. Por que você exige conteúdo, se exige uma série de coisa, sendo que deveria mudar um pouco isso daí, conscientizar, conversar, orientar. Só caderno, livro, giz e lousa não, ficou provado que não ta dando certo.

Então eu tenho um fundamento, pra qualquer coisa que se esteja prejudicando os adolescentes o governo tem que pensar em entrar, pela educação pela escola.

Não é tão função específica da escola, mas acho que a gente ta no todo. Nós somos o reflexo da sociedade, se nosso aluno lá fora fuma então ele é nosso aluno, nosso problema também.

Por exemplo, a escola poderia ter o dia do esclarecimento, isto é, o dia que a gente pudesse falar do problema do cigarro. Uma vez no bimestre, uma vez no semestre, uma vez no ano. Vamos pensar com relação ao cigarro tal dia. $O$ que a gente pode ta trabalhando. $O$ que a gente pode ta passando pro aluno, o que a gente pode ta mostrando pra ele as conseqüências do cigarro. Eu acho que é uma preocupação nossa também. Sem duvida, é da escola também. Inclusive, a gente deixa passar muito, até porque muitos de nós, direção fuma. 
E a gente tem que cobrar, mas também tem que elogiar. Eu sempre falo, a gente perde muito tempo falando daquele que dá problema, esse dai a gente deve orientar, mas também temos que enaltecer os excelentes, se não fuma, nos temos que fazer um trabalho ótimo pra ele nunca fumar.

As meninas, que tem a paquerinha que fuma tudo bem. Você pode paquerar o garoto, não o cigarro. Você precisa fumar pra ele perceber que você existe? Existe outras maneiras. Então, não sei. Eu acredito que seja por aí.

\section{IDÉIA CENTRAL B- Já existe.}

Os professores já abordam. Os professores de outras disciplinas até fazem um trabalho interdisciplinar e trabalham em cima disso com cartazes, fazem seminários. Esse trabalho já existe.

\section{IDÉIA CENTRAL C- Acho válido, porém com outra linguagem.}

Ah, eu acho que é válido. Eu acho que a escola, essa coisa educadora mais ampla, entra isso também. Eu acho que a gente tem que pensar numa outra linguagem.

Não aquela coisa muito tradicional, porque eles vão achar que tão fazendo um trabalho como qualquer outro trabalho. Ai eles fazem lá, uma cartaz e colam umas coisas e depois eles vão fumando pra casa. Não adianta nada.

Então, se é pra fazer um projeto que realmente mude o comportamento deles então eu acho que tem que ser uma coisa pensada, eu não tenho muito receita pra isso, Talvez palestras, talvez com pessoas que choquem um pouco, talvez alguma coisa assim, alguma coisa mais real e não a gente, não os professores que tão sempre, todos os dias.

É difícil você falar alguma coisa, ele acha que você nunca sabe nada, que você nunca tem experiência de vida, é difícil ele admitir que você tem.

Talvez uma pessoa que tenha quase morrido por alguma doença por conta do cigarro, alguma coisa. A pessoa que tenha uma articulação muito boa, um jeito muito bom de fazer palestra, prenda a atenção de jovens.

Talvez isso, talvez mais ou menos esse lado a gente conseguisse, não com todos obviamente, mas com algum grupo.

Não adianta você ta mostrando que nem tem na capa do cigarro. Na caixa do cigarro, tem um cara bonitão e depois ele lá morrendo em conseqüiência do tabagismo. Aquilo lá chocou a princípio, agora que já tá acostumado com aquela imagem, não adianta.

Eu acredito que você pode dar voz pra eles, eu acho muito importante. Eu já tentei esse caminho e vi que o resultado é muito melhor.

É como na escola particular, que você trabalha muito mais isso de fazer seminário, fazer eles pesquisarem. Eu era cobrada muito nas escolas que eu trabalhei essa coisa do aluno pesquisar. E quando eu vinha, eu tinha que lincar isso, fechar o assunto. A fala deles era muito mais bem elaborada que se eu tentasse fechar isso na cabeça deles.

Agora na escola pública, por questão de superlotação na sala de aula, você vai tentar fazer um debate, nem todos tão centrados naquele que ta expondo ali na frente. 
Dispersa muito. Então você teria que criar grupos menores. É mais difícil de administrar isso.

Eu acredito que seminário ajuda. Pesquisa ajuda, mas pra manter a atenção, quando não tem um material lá na frente o aluno dispersa, acha que não está interessante, não quer ouvir, ou o colega fala muito baixo.

Administrar uma quantidade muito grande de alunos em sala de aula é complicado. Eu já tentei, no estado quanto menor os alunos, mais difícil é você aplicar um seminário, aplicar um debate. No Ensino Médio já não. Você pega e faz um trabalho de grupo, faz um seminário a classe respeita muito bem. Ele já gosta de ouvir o colega falar, já tem uma outra mentalidade, daí quer ver o que o colega trouxe. Ele analisa, né? Ele não derruba a aula do colega. É questão de respeito, ele já adquiriu esse respeito pelo colega. Então é um pouco mais fácil de trabalhar.

Só que, ali é mais a conseqüência já do que ta acontecendo. Não previne já se instalou o vício. Aquele que tem que entrar no vício, entra. É muito difícil, com 16, 17 anos entrar.

O trabalho de conscientização, eu acredito que pouquinho, pouquinho, tudo mundo, todos os professores acabam fazendo. Mas que causa impacto neles, tem que ser alguma coisa muito bem planejada. Muito bem pensada.

\section{IDÉIA CENTRAL D- Válido se envolver pais e comunidade.}

Eu acredito que os projetos são válidos, né? Tudo o que vem pra somar, pra ajudar, é válido, vale a pena investi nisso, mas eu não acredito também no resultado. Porque nossa realidade, ela é muito cruel nesse sentido.

Não sei se adiantaria um trabalho feito apenas com aluno, só com aluno, mas no meu ponto de vista deveria ser feita envolvendo família escola comunidade $e$ participação da sociedade como um todo porque ação individualizada por projetos, em minha opinião não resolve.

\section{IDÉIA CENTRAL E- Válido se o professor for preparado para isto.}

Se o projeto trouxer um material e também ajudar o professor a ter mais informações sobre isso eu acho válido. Por muitas vezes os projetos chegam à escola e assim você tem que fazer aplicação num espaço muito curto de tempo.

O professor não tem tempo pra preparação adequada e quando você vai fazer a realização do projeto ele fica com aqueles buracos e você tem a impressão que o projeto não deu certo.

É complicado fazer um trabalho, um projeto, um trabalho mais sério em relação ao cigarro nas escolas. Mas não é para desistir, a gente tem que tentar.

\section{IDÉIA CENTRAL F- Não acredito na eficiência dos projetos.}

Eu não acredito na eficiência disso, viu. Eu acho que informação todo mundo tem. O próprio maço de cigarros vem escrito, entendeu? O cara que fuma, fuma porque ele quer fumar mesmo. 
Eu acho que não funciona. Esse tipo de coisa acaba sendo uma propaganda para aumentar o tabagismo na escola. Porque todo mundo que fala inclusive da maconha só fala dos malefícios. Só que vem outra diz os benefícios. Você é mais importante de quem te disse do benefício? Não, você é menos importante. Então muitas vezes esse projeto de tabagismo na escola acaba sendo uma propaganda favorável ao experimentar.

Eu acho que o adolescente é uma curiosidade e tal, rebeldia, não sei o que mais, mas é também porque existe tolerância. Não deixou, acabou, pô!

Porque que antigamente ninguém fumava? Eu não acredito muito nesses negócios. Projeto. Isso aí fica tudo no papel e enquanto não tiver uma medida mesmo. $O$ que que acontece? Nada. Os incomodantes é que se retirem, não os incomodados.

E, os projetos muitas vezes vêm de cima pra baixo, e quem tá aqui, nós professores e alunos muitas vezes não conseguimos realizar os projetos porque não é a realidade que eles imaginam, né? Vem lá o projeto bonitinho, com objetivo tal, tal, tal e num tempo pra ser desenvolvido e que ele não consegue ser desenvolvido, ou então porque não tem como desenvolver.

Tal dia a gente vai fazer isso, aí a gente não consegue fazer, ou porque não entra na cabecinha deles que isso pode ser prejudicial pra eles. Então existe uma diferença, um abismo entre quem faz o projeto, quem planeja tudo e a realização dele e até dar certo ou não.

Eu acho que isso acontece, em vários lugares, não só aqui na rede estadual, que eu trabalho também no particular e é assim muito difícil a gente conseguir que um projeto avance, né? No particular não tem Secretaria, não tem Diretoria, a Diretoria de vez em quando aparece, a supervisão de vez em quando aparece, mas tem ali a diretora da escola tem a coordenadora e têm os professores, a gente planeja, mas é muito difícil conseguir chegar no objetivo.

Nos vamos sempre cair na mesmice, vamos ter campanhas, vamos ter palestras e eles vão continuar fumando. Adolescente é muito radical.

Uma vez com relação, as DSTs a pessoa falou, tem que mostrar mesmo, tem que mostrar aquelas coisas escabrosas, que é pra ele sentir os efeitos.

-Gente! Mas isso choca.

Não. Tem que mostrar. Esse é o único jeito do adolescente se tocar, mas a gente fica chocada. E talvez seja isso, talvez a gente precise ouvir um pouquinho eles e usar um pouquinho os recursos deles, mesmo sendo agressivo. Porque a gente vê na fala deles um com o outro, quando você coloca assim:

- Alá, ta começando a usar drogas. É tonto.

Ele tem essa leitura, e muito assim, de igual pra igual e quando é de igual pra igual eu acho que atinge mais. E deixar eles falarem, deixar eles fazerem essa experiência. A gente é muito polido, muito teórico, tudo muito bonito.

Eu sempre pensei, no dia que eu conseguir fazer um programa que eu atinja o psicológico deles. Então eu vou fazer. Enquanto for só de palestra, mostrar coisa assim muito igual, mesmice, não. Você tem que pegar com outro aspecto, não só ficar mostrando categorias, as teorias, não.

Quando é projeto no meu nome eu invento lá que eu fiz um monte de projeto, mas é só nome. Quando vai trabalhar o projeto é muito difícil. É um trabalho árduo. É 
um trabalho de equipe. Eu não entro em campanha por causa disso. Da droga eu acho muito difícil. Não consegui até hoje elaborar. O dia que eu conseguir fazer, eu faço.

\section{IDÉIA CENTRAL G- Não vejo necessidade.}

Não sei se tem a necessidade. Acho que não tem a necessidade.

Eu acho que no máximo pode ser trabalhado as conseqüências. Não é um vicio tão grave como drogas né? Eu acho que e mais leve, mas que prejudica também.

\section{IDÉIA CENTRAL H- Não faria porque fumo.}

Olha, eu sou suspeita.

Como eu vou fazer um projeto pra não fumar se eu fumo? Eu jamais poderia fazer isso. Porque o que eu vou falar?

-Não fumem que faz mal?

Eu acho que o aluno, é aquilo, faça o que eu digo, mas não faça o que eu faço. Eu acho que não é por aí. Aí fica desacreditável, professor fazer isso.

Agora se determinado professor que não fuma, eu jamais faria um projeto pra não fumar. Não saberia como fazer. A não ser que tivesse alguém que dissesse é assim: olha, eu fumo e as conseqüencias disso.

Eu não saberia fazer um projeto de tabagismo pra não fumar e eu fumando.

Ao questionar: "Você quer falar mais alguma coisa sobre tabagismo?", a pesquisadora buscou que o entrevistado estabelecesse sincronicidade do tema com a necessidade de falar ainda mais sobre o assunto durante a realização da entrevista, podendo, assim, expressar os pensamentos intercorrentes elaborados.

A Tabela 10 e a Figura 15 explicitam a porcentagem de respostas obtidas a partir da pergunta: "Você quer falar mais alguma coisa sobre tabagismo?", para cada idéia central categorizada. 
Tabela 10: Número e proporção $(\%)$ de respostas dadas pelos professores de acordo com as Idéias Centrais" da pergunta "Você quer falar mais alguma coisa sobre tabagismo?". São Paulo, 2006.

\begin{tabular}{lcc}
\hline \multicolumn{1}{c}{ Idéias Centrais } & No & \% $^{\text {** }}$ \\
\hline Não, mas acho que a escola deveria mesmo tratar o tema & 10 & 26 \\
Sou contra propaganda & 2 & 5 \\
Não, nada & 10 & 26 \\
Atitude do adolescente & 5 & 13 \\
Não sei o que funciona & 2 & 5 \\
Relaciona o tema com outras drogas & 3 & 8 \\
Problema muito complexo & 5 & 13 \\
Projeto de tabagismo nunca vi, mas seria legal trabalhar & 1 & 3 \\
Aconselha as pessoas a parar de fumar & 1 & 3 \\
Preocupa-se com o não fumante & 1 & 3 \\
Relaciona efeitos do tabagismo com efeitos da poluição ambiental & 1 & 3 \\
Ressalta que o preço do cigarro é muito baixo & 1 & 3 \\
Ressalta a necessidade de uma aliança social & 2 & 5 \\
Estabelecer parcerias com área da saúde & 1 & 3 \\
Toma consciência dos transtornos decorrentes do fumo & 1 & 3 \\
\hline total & $\mathbf{4 6}$ & \\
\hline
\end{tabular}

*possibilidade de mais de uma Idéia Central por indivíduo.

**calculada em relação ao total de professores. 
FIGURA15: Proporção $(\%)^{*}$ de resposta dadas pelos professores de acordo com as Idéias Centrais da pergunta "Você quer falar mais alguma coisa sobre tabagismo?". São Paulo, 2006.

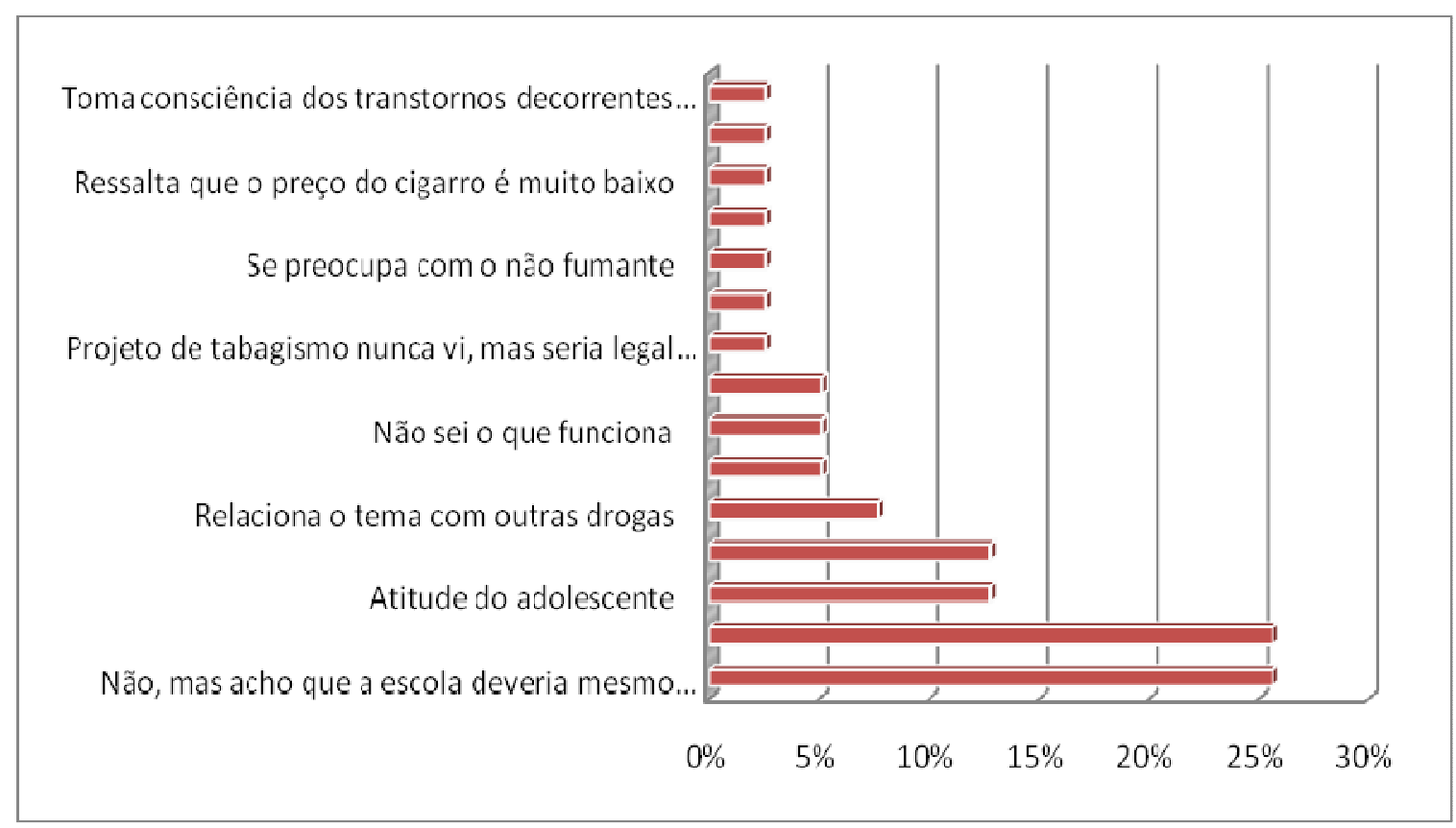

*calculada em relação ao total de professores.

DSC obtidos a partir da pergunta 7: "Você quer falar mais alguma coisa sobre tabagismo?"

\section{IDÉIA CENTRAL A- Não, mas acho que a escola deveria mesmo tratar o tema.}

Não. Tá tranqüilo, mas eu acho que deveria mesmo introduzi isso ai na escola. Porque eu trabalho de manhã com eles, com adolescentes.

A gente vê eles fumando aí no pátio e fica morrendo de dó. Porque de repente não tem quem explica em casa. Ele vê o colega acha legal, e entra por falta de instrução. Ao passo que se a escola trabalhasse, mostrasse o lado ruim disso, porque lado bom não tem nenhum, de repente ele ia pensar duas vezes.

É esse problema das pessoas que tem assim vários exemplos na família, o irmão da minha mãe, ele também morreu fumando, sofrendo, não podia nem respirar. A respiração dele era um décimo de respiração, mas ele não largou o fumo.

Também as filhas dele nunca fumaram e eu acho que se a gente mostra esses exemplos pros alunos na escola eu acho que vai ajudar. $O$ sofrimento, as doenças que causa, o pulmão. 
Assim como as drogas causam problema no sangue, no organismo, o cigarro causa também, no pulmão principalmente, na respiração, quem tem problema de asma, bronquite, é um horror. É isso aí.

Eu acho que é uma mensagem que a gente tem pra mostra, pra conter isso, esse impulso. Só que com uma preparação bem feita do professor. Se o projeto for bem estruturado ele vale a pena ser aplicado na escola. E assim, seria interessante não só com relação ao tabagismo, seria interessante mais interação dos professores, com qualquer outra campanha, qualquer outro assunto, união dos professores pra poder trabalhar com isso.

A gente tem grandes índices de usuário de drogas numa escola, então a gente poderia trabalhar todos os professores juntos. Ou então se a gente tem um grande número de crianças com determinada doença, aqui a escola tem várias favelas do lado, então a gente percebe que têm crianças que passam fome, crianças que vêm pra escola só pra poder se alimentar, então deveria trabalhar isso, não sei de que jeito.

Eu acho que também as idéias surgem com a discussão de todos juntos. Não é? Mas talvez isso fosse uma maneira de melhorar o que nós temos aqui hoje.

Eu acho que existe muito empenho dos professores pra que as coisas melhorem. E eu gostaria muito que esses empenhos fossem lavados a sério. Eu participo do que eu posso participar, e assim eu comecei meio tímida, né, mas eu fui criando as minhas asas e hoje eu consigo fazer algumas coisas. Não muitas, mas eu consigo fazer algumas coisinhas. Porque às vezes se esbarra em alguma coisa que aí depois a gente desiste, desanima, e aí não tem vontade de continuar.

Nosso papel não é pequenininho, e se a gente pensa assim, ah, eu vou fazer o meu papel só dentro da minha área, que nem a gente trabalha aqui com matéria, se fosse de primeira a quarta série seria uma coisa, mas se eu for pensar só na minha aula, o que eu vou fazer dentro da minha aula, eu vou tá me anulando e dizendo assim: não me interessa o que acontece nas outras. Não, eu preciso saber o que tá acontecendo na escola porque eu trabalho aqui. Eu quero conhecer os meus alunos, eu converso com eles.

-Ah, mas é aula de inglês professor. Não, mas a gente vai ter que ter essa conversa agora.

Se divulgasse mais nas escolas... Porque infelizmente em casa não falam... Mostrassem mais as conseqüencias negativas do cigarro, seria muito bom.

\section{IDÉIA CENTRAL B- Sou contra propaganda.}

Ó, o ministério da saúde, eles fazem primeiro a sua propaganda, pra depois por aquele pedacinho, aquela tarjinha assim: Fumar é prejudicial à saúde.

Eu acho assim que eles deveriam não fazer propaganda do cigarro na televisão, né? Que seria o ideal eles mesmos consumirem por conta própria. Não através de anuncio de cigarro, propaganda de cigarro pra depois por aquela tarjinha. Aí sim deveria ser um trabalho de prevenção.

Eu acho que o fato de não se ter mais propaganda de cigarro na televisão foi uma grande coisa, mas mesmo assim ainda o índice é muito alto. 


\section{IDÉIA CENTRAL C- Não, nada.}

Não. No momento assim não. É só. Pra mim tá bom. Essas perguntas que foram feitas, foram todas adequadas. Eu acho que você já abordou tudo.

\section{IDÉIA CENTRAL D- Atitude de adolescente.}

Hum, no momento não. É assim...

A questão é a seguinte, eles começam, na realidade por conta de curiosidade, que é por volta de onze, doze, acho que no máximo treze anos que eles têm suas descobertas.

Então começa com essa coisa de fumar escondido, faz uma coisinha aqui, faz uma coisinha ali e quando vê criou-se hábito de fuma e vai embora, né? A não ser que a pessoa tenha um problema sério, que ela passe a ter consciência de que aquilo é um mal hábito pra poder encerra.

$O$ adolescente, ele é mesmo conduzido, ele é levado a experimenta e alguns tem o organismo predisposto ao vício. Porque tem alguns que experimentam e não têm outros que já, depois de algumas vezes tem aquela necessidade, mas, como a nicotina é altamente viciante e a partir de curta idade, a pessoa vai pegando aquela angustia aquela coisa e como se fosse um instrumento.

Pra ela descarregar as angústias e ai que ela não larga mais, junta os dois fatores né? Junta o fator da nicotina que e viciante e o outro fator, ai e difícil.

Na fase de adolescente é possível fazer alguma coisa, mas na fase adulta é muito difícil. Ai a pessoa vai sofrer, pra caramba, pra largar.

E tenho também o meu próprio exemplo que eu tentei ser fumante por certa vez até por esse glamour que a sociedade coloca, relacionada ao cigarro então é uma espécie de glamour aquele que fuma no filme Casa Blanca, aquilo é um charme, não é? Isso desperta a curiosidade. Pra você ser aceito socialmente. A beleza. Então tentei fumar, graças a Deus meu organismo não aceitou e até desmaiei, tive um desmaio e nunca mais me senti atraída por aquilo.

Eu creio que as pessoas devem iniciar outra espécie de glamorização que não seja um vício. Pra ser aceito. Isso talvez devesse ser um passo pra ser discutido, pra ser falado. Outras maneiras pra ser aceito pelo grupo pela sociedade.

Você tem que estudar primeiro o adolescente como ele é, a cabeça dele, no mundo dele, pra trabalha isso. Do adolescente que mora na favela, do adolescente que mora num condomínio de alto padrão, porque ele tem outras necessidades ali. Então ele tem que se acostumar naquele grupo. Entendeu?

É assim, determinados grupos exige certas posturas. Tá mostrando pra pessoa que ela pode ta naquele grupo, mas ter outra postura. Trabalhar também o grupo pra aceitar as diferenças. 


\section{IDÉIA CENTRAL E- Não sei o que funciona.}

Eu acho que o esforço que fizeram até agora na escola, mesmo o pessoal da PM que ta fazendo palestra aí, né? Em termos de esclarecimento tudo, já vi muita iniciativa. Mas eu não sei, pra te falar a verdade o que que funciona.

Por exemplo, em casa eu tive um exemplo engraçado, a minha filha quando tinha 14 anos, ela resolveu que ia fumar. Disse ela que ia fumar tal, e dai ela chegou pra minha mulher e falou que comprou cigarro, afrontosamente. Deixava na bolsa, saia e fumava. Ai eu falei pra ela:

- Olha, eu acho que pra fumar você deveria esperar pelo menos fazer 18 anos.

-É todos os colegas fumam.

Ah, então tudo bem, então fuma logo uns 19 maços por dia que é pra você ter... você quer sentir o gosto.

E daí ninguém proibiu. Eu via ela fumando, fazia de conta que não tava vendo. E então ela pegou nojo do cigarro.

Hoje ela não pode nem ver nem o maço. Mas em questão de meses, ela parou. Quer dizer, só experimentou.

Tem que ser assim uma coisa menos repressora, pro pessoal poder mostra realmente quem é. Uma coisa mais aberta, mais sossegada, mostrando que não é pra reprimir, mas pra conscientizar. Primeiro lugar pra conscientização, porque adolescente com repressão, ele faz ao contrário. Não dá certo...

\section{IDÉIA CENTRAL F- Relaciona o tema com outras drogas.}

$E$ É eu entrei até no assunto das drogas porque é o que nós vivemos assim de mais imediato e de mais duro de lidar. Triste, eu diria. É uma realidade que salta todo dia na nossa frente e nós nos sentimos impotentes. E é triste conviver com isso e não ter meios, não ter apoio pra consegui lidar com isso.

Eu acho legal eu ta falando, no caso, pra conscientizar todo mundo que o cigarro não traz benefício pra ninguém. Cigarro, no caso é um vício, o fumo é uma droga, como disse anteriormente, como a maconha como crack. É uma coisa que ele mesmo tá se viciando, mas o próprio nome dele ta falando, ta fazendo muito malefício pra ele mesmo e pra pessoa que ta ao reder dele. Que esse vício do cigarro pode transformar depois dele fumar um cigarro viu que não dá em nada, ele pode procurar alguma coisa mais forte como a maconha, como a cocaína, como o crack.

Eu acho que quando a gente fala sobre drogas, a abordagem deve ser feita com muito cuidado, é muito sutil. E às vezes acho que precisa de um tratamento de choque, a gente precisa mostrar os efeitos que aquilo causa pra que aquilo cause impacto, né?

Então eu acho que é como quando a gente fala da questão da AIDS. Quando a gente fala parece que é uma doença comum, como o câncer. E olha, o doente portador do HIV em fase terminal é terrivel.

Então eu acho que o aluno deveria ver mesmo os efeitos pra que aquilo chocasse e ele parasse pra pensar mais profundamente. 


\section{IDÉIA CENTRAL G- Problema muito complexo.}

Eu acho que o negócio do tabagismo como da bebida alcoólica também, do álcool é muito complexo isso. Entendeu?

Vai passar pelo problema psicológico também. Cada comunidade tem suas necessidades, tem que ser uma coisa voltada pra comunidade mesmo, o entorno, mas eu acho que se tem mais pra se falar, não tá esgotado esse assunto.

Eu tenho um pai que teve um câncer de boca. Em função de cigarro provavelmente, e foi retirada a metade da mandíbula. Até então eu achava que ele tinha razão em algumas coisas que ele dizia que era um prazer.

Então na minha cabeça até pouco tempo atrás essa coisa de fumar era o prazer dele, então eu chegava a defender. Já que tem tantas outras coisas que nos trazem transtornos e problemas, né?

É um assunto que trabalha subjetividade individual, psíquica, social da pessoa. Então isso requer certo cuidado. Porque, que tem efeitos tem. Malefícios, benefícios, sei lá. Físicos, psíquicos...

Resta saber se a pessoa deixando, parando de fumar, será que ela vai ter realmente uma qualidade de vida? Ou será que outras coisas poderão ser buscadas para suprir aquilo que foi tirado?

Essa é uma pergunta que eu... uma psicoterapia, ou uma terapia ocupacional, né? Não sei, porque alguma coisa tem que ta suprindo.

Então eu acho que se você for barrar muito, desperta mais a curiosidade. Eu acho que na escola, por exemplo, é barra você saber o que você vai fazer.

A não ser que você tenha uma legislação de apoio que eu acho. Olha, não pode fumar aqui. Você ta fumando.

Sei lá, dá uma suspensão, vamos supor que tivesse uma penalidade desse tipo, né? Porque a gente não tem ação. Falar não adianta.

Minha mãe dizia o seguinte:- Palavra não dói.

Porque os caros não têm consciência, não adianta.

\section{IDÉIA CENTRAL H- Projeto de tabagismo nunca vi, mas seria legal trabalhar.}

Olha, eu achei interessante essa tua pergunta de projeto de tabagismo nas escolas porque eu leciono a tantos anos e eu nunca vi.

Quase 20 anos que eu dou aula, nunca vi campanhas assim, pouquíssimas vezes, umas duas vezes.

E no dia-a-dia nós temos tantas atribuições é uma coisa que seria importante pra molecada. Mesmo assim na área de português, até é uma idéia boa trabalhar com a meninada porque eles são muito novinhos, né? Eles vão pelo movimento dos outros. Se não tiver bons exemplos, pessoas que indiquem.

E a escola é um espaço importantíssimo. Porque a gente tem tanta coisa que suprir do aluno. Essa é uma das coisas.

Nós tivemos aqui um projeto voltado pra problemas do coração. Projeto do INCOR. Foi muito bom. Já tivemos projetos contra as drogas, o PROERD, que a polícia ajudou. Então é uma sensibilização. Muito fácil. Hoje em dia os pais não ajudam muito 
na formação dos adolescentes. A escola está sobrecarregada, mas seria muito interessante pra gente colocar no planejamento durante o ano pra conversar com os professores.

È realmente é difícil, a gente ta sobrecarregada, mas seria uma coisa legal de ta trabalhando.

\section{IDÉIA CENTRAL I- Aconselha a parar de fumar.}

Que gostaria de dizer? Que as pessoas que fumam, que elas é claro que deve ter um certo grau de dificuldade. Eu não sei falar porque eu nunca fumei, mas se pudesse parar com essa prática que não traz nenhum bem. É, você só queima o seu dinheiro e a saúde.

Claro que eu to sendo assim, cada um faz o que quer, o dinheiro é seu, a vida é sua, mas eu se fosse falar alguma coisa assim falaria:

- Tente parar.

-É algo assim que ta complicando a tua vida. Tá gastando seu dinheiro e além do mais se você fumar perto das pessoas que não fumam e que tem problemas respiratórios você, vamos dizer assim, tá trazendo o mal pra essa pessoa que tá do seu lado.

- Você tá poluindo. Tá realçando o mal pra pessoa que tá ao seu lado.

\section{IDÉIA CENTRAL J- Preocupa-se com o não fumante.}

Não, eu acho que não.

A única coisa que eu acho é que as pessoas que fumam deveriam ter consciência de que se o vício é delas, os outros não tem que ser afetado. Então, que você tem que saber se colocar na hora certa, a hora que tem que fumar. Que às vezes tem muita gente que não sabe.

Tem gente que acende o cigarro, não tá nem aí. Não sabe nem se a pessoa que tá perto fuma, se a pessoa gosta de cigarro ou não.

\section{IDÉIA CENTRAL K- Relaciona efeitos do tabagismo com efeitos da poluição ambiental.}

Eu gostaria de te falar que eu tenho a capacidade. Se eu quiser eu paro. Eu não sou tão dependente assim. Me dá prazer. Eu gosto. Mas se eu, como já aconteceu de eu parar, e parar por longos anos.

E se eu decidir, eu vou parar. Eu não entro em depressão por isso não e ainda tenho a intenção de parar.

Eu poderia te dizer que em determinados momentos eu acho muito deselegante. Eu acho uma falta de educação fumar em restaurante.

O mal que causa internamente pra mim é questionável, ta? Eu sei que tudo que se faz nessa vida faz mal. Até comer faz mal. Comer gordura, agora assim, só o cigarro me proporcionou bronca. 
Minha mãe nunca fumou. Meu avô morreu com 98 anos, fumou a vida inteira. Mentira, ele parou quando tava com 70. Decidiu que ia parar mesmo porque é uma obrigação fumar. Porque se ele não fumasse ele era comido pelos pernilongos. Era fumaça pra espantar mosquito. Aos 70 meu avô parou e morreu com 98.

Sei lá, eu sei que não é bom comer gordura, mas até quanto só o cigarro é prejudicial. Quanto aos males, eu até questiono. Não sei se é ignorância minha, mas até questiono mesmo. Quem fuma dois maços de cigarro por dia e mora no campo acho que fuma menos cigarro do que quem fuma nada e mora em São Paulo. Poluição atmosférica. Então é muito relativo até.

\section{IDÉIA CENTRAL L- Ressalta que o preço do cigarro é muito baixo.}

- Não, não.

Ah! Eu acho uma coisa que eu não falei e que você também não perguntou, eu acho que o cigarro tinha que ser muito caro. O preço barato é igual à pinga.

Porque que tem tanto bêbado? Porque a pinga é muito barata, sabe? Então o cigarro também é muito barato para o que eles têm na mão. Entendeu? Qualquer um real eles vão lá e compram nem que for um ou dois cigarros entendeu? E compra picado, eles abrem o maço, vendem por 50 centavos, sei lá eu quanto que é e aí a pessoa sempre tem como fumar entendeu?

Então assim, o preço tinha que ser lá em cima. Assim diminuiria a quantidade de quem vai se interessar.

O poder aquisitivo também tem que ser muito alto pra poder comprar. Aí eles iam falam que eles iam roubar né? (risadas) Tem esse porem. Bom mas seria um meio de tentar diminuir.

\section{IDÉIA CENTRAL M- Ressalta a importância de uma “Aliança Social”.}

Não.

É, mas o que a gente percebe, eu vejo assim, que precisa uma aliança social, aí a coisa funcionaria bem. Por quê?

Você vai a um bar, em qualquer estabelecimento, uma criança compra cigarro, tranquilamente. Eu te digo porque, é proibido por lei, mas vendem. Infelizmente a gente vê pais, tio, tia:

-Ah, vai lá pra mim. Dá um pulinho lá, compra um maço de cigarros.

O dono do bar conhece, é como se diz, você conhece. É sobrinho de tal pessoa, é filho de tal pessoa, ele acaba vendendo porque sabe que é pro pai.

Mas também é aquela coisa, na hora que a criança for lá, se não é pro pai mais, se é pra ele, a própria pessoa do estabelecimento, porque vai, é seu conhecido, acaba afrouxando essa situação. Não tem aquele pulso firme de falar, não vou vender, pede pro seu pai vir e comprar e acabou. Porque ele pensa no lucro, ele pensa na situação dele.

Então aí que eu falo, falta essa aliança social, a conscientização em termos de mercado. Esse é o primeiro ponto. 
Segundo, se a criança tem contato muito cedo, com pessoas que ela tem realmente convívio, a tendência é ela falar, bom se meu pai faz, eu também faço.

Então você teria que fazer um trabalho junto à família. Porque aqui, eu vejo assim, o Estado nos proporciona capacitação, trabalho. Nós fizemos semana de prevenção disso, daquilo ta , ta, ta, trabalha toda essa geração esse ano.

É que nem o caso da dengue há uns anos atrás, foi trabalhado assim vastamente dentro das escolas. Se você pegar um aluno dessa geração e perguntar pra ele o que pode e o que não pode fazer, ele sabe te falar de cor e salteado e pode prevenir.

No entanto, ele tem uma mãe que sabe e que não ta nem aí. Então isso que eu acho complicado. E essas alianças, a gente tenta fazer, trazer a família pra escola, pra esse tipo de debate.

Muitas vezes não existe um interesse social, de vir também junto com a criança pra aprender alguma coisa de bom pra ela. Então é família, é escola aberta aos finais de semana, não estou vendo um direcionamento.

Então eu acho assim, as nossas propostas são muito boas. Você forma uma geração? Não sei, eu acho que com oito anos já deu pra formar alguma coisa. E eu não to vendo esse reflexo lá fora, né? E é isso que entristece. Talvez, quando eles formarem família, tiverem seus filhos, e vê que este trabalho continue e eles terem uma posição de pai, ele mude.

Eu acho importante a gente prevenir, a gente falar em todos os sentidos, ta semeando nessa geração pra ver se no futuro a gente consegue alguma coisa. Mas, desde que eu comecei a trabalhar, há oito anos, o meu maior entrave, é esse lado família não participar. E por mais que você tente é complicado.

E eu acho que a mídia é importante, infelizmente é a única que propaga. Eles que são capazes de realmente colocar, em segundos, uma fala que vai conscientizar realmente o social.

Então eu acho que eles também não terem a mesma fala da escola, é difícil.

\section{IDÉIA CENTRAL N- Estabelecer parceria com área da saúde.}

- Eu acho que eu já falei até bastante. Muita coisa.

Sei lá, talvez a área de saúde fazer uma outra, uma opinião. Um trabalho diferenciado aí com o pessoal. Porque eles não fazem assim, é de colesterol, tem né?

Eu vejo lá no posto de saúde, o pessoal faz caminhada, promovem sempre em posto de saúde. Então você vê umas coisas que deve fazer parte de algum projeto que eles fazem lá.

Você vai lá ao posto, tem problema de coração, ta obesa, num sei o que, tem uns projetos, tem caminhada, algumas coisas e eu não sei, pode ser que tenha em relação ao cigarro, eu estou por fora.

Ali dentro do posto de saúde, não só dentro da escola, porque a gente trabalha muito com os alunos, mas não com os adultos.

Seria interessante, uma parceria. E mesmo praquelas pessoas que tem dificuldade pra parar de fumar. 
O Centro cultural da Juventude é da prefeitura, dentro desse centro também pode desenvolver umas coisas assim, porque o posto de saúde não fica aberto direto. Muitas vezes ele não pode ficar direto em períodos que os adultos possam ir.

Por exemplo, tem período que funciona assim das sete das oito e as pessoas não podem. Então às vezes o pessoal da saúde também pode usar esses locais pra esse tipo de desenvolvimento dessas coisas. E lá no Centro Cultural tem que apresentar um projeto pra poder usar a sala, é lógico que tem que apresentar um projeto gratuito pra população mesmo. É um caminho também.

\section{IDÉIA CENTRAL O- Toma consciência dos transtornos do fumo.}

Só que, com o passar do tempo, eu percebi que o cigarro é mais uma coisa que traz mais um transtorno, mais um problema. Então não é uma coisa que é imediata, mas ocorre e poderia ser evitado também.

Eu acho que a gente é muito imediatista mesmo. E a gente peca por não ta tendo uma visão futura mesmo, por não querer pensar muito no futuro. Às vezes passa o dia, só quando chega no fim do dia que a gente se deu conta. Então não sei se por questão da idade eu acho que também o pensamento ta voltado mais a questão do tempo. Hoje em dia então eu to tendo maior preocupação em ta revendo algumas coisas e tentar modificar, apesar de que ta difícil.

Eu sinto hoje em dia que como passou muito tempo mudar determinados hábitos é difícil, bem mais difícil.

Os resultados em gráficos e tabelas obtidos diretamente do QualiquantSoft, programa de informática utilizado, encontram-se disponíveis para análise no Anexo 6. 


\section{Discussão}

"Homens e Mulheres desejam fazer um bom trabalho. Se lhes for dado o ambiente adequado, eles o farão".

Bill Hewlett 
As representações que permearam as respostas aos questionamentos propostos são discutidas aqui, apoiadas em pesquisa científica de autores que, com seriedade, tornaram público seus trabalhos. Sendo impossível esgotar o tema, objetivamos analisar aspectos dessas representações com base no pressuposto teórico da abordagem qualitativa, capaz de incorporar a questão do significado e da intencionalidade como inerente aos atos, às relações e às estruturas sociais apoiadas em construções humanas significativas (MINAYO, 2000a).

No entanto, cabe destacarmos que, segundo DELGADO (2003, p.9), “o conhecimento que construímos sobre o mundo é valorativo e, portanto, humano e subjetivo, que permite a cada um de nós criar uma representação de mundo que, quase sempre, não é coincidente com o mundo, é uma abstração". Além disso, como ressalta FERRAÇO (2002), todo conhecimento que criamos/inventamos revela, em parte, quem somos, é fragmento de nossas verdades/identidades.

O aspecto valorativo e subjetivo construído, destacado por DELGADO (op cit.), leva-nos à reflexão sobre a importância de se expandir os avanços do conhecimento científico para que as verdades produzidas permitam tomadas de decisão assertivas e agregadoras à promoção da saúde no ambiente social.

Com a intenção de contribuir para abertura de um caminho melhor no controle do consumo de cigarro pelos jovens é que refletimos, com base em referencial científico, sobre os DSC dos professores entrevistados.

É de real importância ainda reforçarmos que, embora apenas $13 \%$ dos professores tenham revelado serem fumantes (Figura 2), todas as respostas que contemplaram expressões do tipo, "sou fumante", "sei, porque fumo" ou outras indicativas deste hábito foram agrupadas em categoria própria nas diferentes perguntas formuladas.

Ao discursar sobre o ato de fumar, os entrevistados destacaram vários aspectos inerentes ao vício, tais como: dependência, dificuldade de parar, prazer e bem-estar, ainda que momentâneo, comparando o hábito até mesmo a outras drogas: 
Bom, fumar é um vício que... Como beber, como usar droga, feito uma maconha, uma cocaína... como qualquer outro, faz com que você fique dependente dele.

... Individualmente é uma dependência, porque é nítido que a pessoa se torna dependente é... ansiosa, ... dependente químico...

Realmente, a tabaco-dependência apontada pelo DSC apresentado se deve à nicotina presente na folha do tabaco, que é praticamente absorvida em sua totalidade no fumo inalado. Segundo ROSEMBERG (1985), experiências com nicotina marcadas com radioisótopo mostram que os fumantes tragadores absorvem mais de $95 \%$ de toda essa substância, que passa pelos alvéolos, sendo então absorvida no pulmão.

Não só inalada como também através da absorção cutânea, a nicotina pode causar doenças. Como já dissemos a UNICEF, em 1990, analisando dados mundiais concluiu que é enorme o contingente de crianças que, ao trabalhar em colheita do tabaco, são acometidas pela chamada "doença do tabaco verde". Seus sintomas são identificados, além de outros, por vômitos, dores de cabeça, cólicas abdominais e tonturas (ROSEMBERG, 2003).

A consciência da toxidade no consumo do cigarro também foi claramente manifestada em mais de $40 \%$ dos entrevistados (figura 9), como ilustrado abaixo:

... Eu acho que é a degradação do próprio corpo... É você inalar substância que não é natural, entendeu. Que não tá na natureza disponível de modo natural. É inalar fumaça com tantos derivados aí. Tóxicos que têm dentro do cigarro e outras coisas mais de drogas... É uma autodestruição...

O destaque para a questão de inalar substâncias tóxicas apresentada aqui evidencia a consciência do perigo associado à presença das mais de 4700 substâncias cancerígenas nas folhas de tabaco, independente do tipo, região ou modo como é cultivado (DUBE e GREEN, 1982). 
Interessante ainda identificar que alguns relatos revelaram a permanência da questão de afirmação social e status, padrão de consumo muito reforçado pelas propagandas de cigarro em décadas passadas.

A idéia de desperdício de tempo, dinheiro e saúde, além de falta de educação, embora apontada aproximadamente em apenas 10\% das respostas (figura 9), também fez parte das verdades consideradas na fala dos professores pesquisados. Algumas vezes indignados, prontamente destacaram a ocorrência de consumo de cigarro por professores, funcionários e até mesmo por alunos dentro da escola, contrariando a legislação vigente no país ( Lei 9294/96) de não fumar em estabelecimentos públicos. O fato foi apontado como de responsabilidade da direção escolar, que, segundo os professores, nada faz para reverter esse quadro:

... tem professor que fuma, têm funcionários que fumam, atende pais fumando e não tem nenhuma restrição ao uso de tabaco nas dependências da escola. Você não tem nenhuma ação de diretoria da escola em relação ao cigarro. Aqui, à noite, quando começou o supletivo, piorou neste sentido porque vinham os adultos, eles se achavam no direito de sair entre uma aula e outra pra fumar. A molecada aqui de cima viu que o pessoal do EJA l estava fumando, achou que tinha o direito de fazer a mesma coisa. Então eu acho que é um absurdo a escola não, quer dizer, ter uma teoria tão grande a respeito disso e permitir que professor fume ou que funcionário fume ou que aluno fume...

Em contrapartida, um professor revelou não encontrar problemas com o hábito de fumar, mostrando-se alheio a qualquer prejuízo decorrente da utilização do cigarro:

... Eu não tenho grandes problemas com o cigarro. Não é uma coisa que me agrida, não é uma coisa que me irrite muito...

1 EJA: Educação de Jovens e Adultos implantada pela Del. CEE nº 09/2000 
Outro, embora suspeitando da relação câncer e consumo do cigarro, revelando também conhecimento sobre fumante passivo, relacionou o hábito a leis da honestidade e pudor. Este DSC evidenciou a cautela do professor frente a uma intervenção, já que, em seu entendimento, esbarraria em aspectos da moral do indivíduo:

...Há uma possibilidade de pesquisa que ele realmente provoca câncer ... Quem não fuma, que é o fumante passivo, tem grande probabilidade de ter câncer. Muito mais do que quem fuma. Agora, não é por que eu vou ver uma pessoa com o cigarro que precisa brigar, não sou moralista. Sei lá, tudo tem o seu momento, sua hora, desde que ela fume em local apropriado ...

O destaque ao fumante passivo, apontado por esse DSC, apareceu mais evidente em apenas $40 \%$ das respostas dos entrevistados (figura 10) quando questionados sobre o fato de o cigarro afetar outras pessoas:

Com certeza. Isso é provado cientificamente, que a pessoa que fuma ela tem o... um certo nível de... problemas internos, a nível respiratório e o não fumante que convive com esse fumante ele acaba fumando por tabela.

... É como a gente diz, você é um fumante passivo que ao mesmo tempo em que a pessoa ativa tá fumando, passa também aquela fumaça, a nicotina passa pra você, então você... sofre mais até do que a pessoa que tá fumando.

O conceito de fumante passivo, introduzido em 1993 por HILLMAN e seus colaboradores, já conta com reconhecimento científico, mas não parece ter se constituído em discurso explícito dos profissionais da educação aqui entrevistados, dado que nem a metade deles o apontou em seu repertório de linguagem informal.

No entanto, o reconhecimento dos transtornos provocados pelo cigarro sobre outras pessoas foi inteiramente afirmativo entre os entrevistados (figura 10), e pode ser ilustrado pelos depoimentos: 
... quando eu estou em ambiente limpo, se chegar alguém fumando, por mais discreto que seja, eu sou a primeira pessoa que percebe. Imediatamente eu sinto alergia, minha garganta fica assim como que arranhando, incomodando. Então afeta, com certeza. Isso é pra mim uma coisa impressionante...

Afeta. De alguma maneira afeta. Ou saúde, ou cheiro que fica na roupa... aquela fumaça traz outras substâncias que entra no corpo da pessoa, que faz mal do mesmo jeito da pessoa que tá fumando. Quando eu tô com um pessoal que fuma e...pode ser tarde da noite, eu chego em casa tenho que tomar banho, senão eu não consigo dormir...

O próprio fumante demonstrou consciência de seu ato, não perdendo a oportunidade de revelar que também se sente constrangido em buscar espaço para fumar.

Eu acredito que sim. Tanto que eu procuro fumar sempre em lugar aberto, nunca fumo em sala, que nem a sala dos professores aqui. Na minha casa eu nunca fumo em ambiente que estão as outras pessoas. Eu fumo no quintal, mas eu não consigo parar de fumar. Eu já tentei, mas não consigo.

...Isso incomoda porque, pra quem fuma, também é um tanto constrangedor; a gente fica um meio sem graça de... tá buscando locais onde não incomode outras pessoas. Sem... não muito à vontade também principalmente quando elas externam isso.

A ineficiência dos lugares reservados aos fumantes, em bares, restaurantes e outros espaços fechados, como proteção dos não-fumantes, também apareceu nos depoimentos:

...Eu acho que essa lei de... ter lugar pra fumante e não fumante devia prevalecer e muito... mas não essa mentira, só se for um lugar fechado...e geralmente acontece isso em restaurante. Porque se fica assim duas, três mesas no restaurante longe da pessoa não adiantam, a fumaça... não tem como... 
Essa consciência vem reforçar ações parlamentares, tais como o Projeto de Lei 2035/07, do deputado Raimundo Gomes de Matos (PSDB-CE), que proíbe o uso de cigarros, cigarrilhas, cachimbos e charutos em ambientes coletivos, mesmo que seja uma área restrita para fumantes. Segundo o autor da proposta, os chamados "fumódromos" são considerados pela Organização Mundial da Saúde uma falsa proteção. O deputado ressalta que diversos estudos monstram que a fumaça aspirada pelo não-fumante apresenta níveis oito vezes maiores de monóxido de carbono, três vezes maiores de nicotina e até 50 vezes maiores de alcatrão, nitrosaminas e outras substâncias cancerígenas do que a fumaça tragada pelo próprio fumante.

$\mathrm{O}$ projeto tramita em regime de prioridade e terá análise junto às comissões de Ciência e Tecnologia, Comunicação e Informática; de Educação e Cultura; e de Constituição e Justiça e de Cidadania, além de ser votado em Plenário (Boletim no 34 / ACTbr, 2008).

Essa proposta retoma uma discussão que, desde a elaboração da Constituição de 1988, levou o deputado federal Fausto Rocha (PL) a solicitar a incorporação no capítulo do Meio Ambiente o problema da poluição dos ambientes fechados. Segundo jornal da época, entre uma tragada e outra, a emenda foi rejeitada (ALBANESE e BRUMINI, 2002).

Hoje, em continuidade a essa luta, o Projeto de Lei que elimina os "fumódromos" em ambientes fechados está pronto para ser enviado ao Congresso Nacional (alterando a Lei Antitabagismo Federal 9694/96), o que facilitará muito a fiscalização, além de cumprir com as obrigações do Brasil como signatário da Convenção-Quadro para o Controle do Tabaco.

O que deve ser resguardado é o direito concedido a todos de se manterem em um ambiente livre da poluição causada pelo tabaco, já que para o próprio fumante sua permanência em "fumódromos" aumentaria muito sua exposição aos componentes tóxicos presentes no cigarro. 
Porém, ao que parece, essa proposta reacende uma discussão que contraria proprietários de hotéis, bares e restaurantes, já que a adequação de seus estabelecimentos às exigências da disponibilização de "fumódromos" é fato.

Em contrapartida, as campanhas pela implementação de ambientes fechados $100 \%$ livres de fumo adquirem expressão em vários estados do país. As atividades desenvolvidas em Pernambuco, Paraíba e Sergipe estão ganhando aliados.

Em São Paulo, os secretários estadual e municipal de saúde se declararam comprometidos com o tema, sendo que se encontra em fase de negociação a forma como a lei poderá ser fiscalizada e cumprida no maior estado do Brasil.

A presença de projetos dessa ordem possibilita uma militância contrária à expansão da indústria de cigarros, que, ainda hoje, tenta manter o posicionamento de que não existem provas de que o fumo passivo provoca doenças. Mesmo que cientificamente mostrado, os índices de câncer de pulmão, doenças do coração entre outras são muito maiores em fumantes passivos do que em pessoas não expostas à fumaça do cigarro e a outros derivados do tabaco (MUST E COL., 2004), como vimos, a mesma indústria busca se infiltrar e sorrateiramente presenciar encontros pautados na busca de novas medidas de proteção aos não-fumantes.

Ainda referente ao questionamento sobre o cigarro afetar outras pessoas, foi destacado o papel do professor como exemplo de comportamento:

... O aluno faz o que o professor faz, e muitos me pedem pra sair pra fumar ...Adolescente, de 12 a 19 anos não pode fumar. Ele diz... como a professora fulana de tal sai pra fumar? Entendeu? E aí, eu acho péssimo... quando na sala dos professores, que eu considero extremamente negativo, um professor fumar...

O protagonismo do professor e o desenvolvimento da profissionalidade docente, segundo ALARCÃO (2001), realmente colocam esse profissional como ator de primeiro plano. 
Além disso, "a politicidade da educação exige do educador, de um lado, que eleja a serviço de quem quer estar, de outro, que diminua a distância entre a expressão verbal de sua opção e sua prática" (FREIRE, 1996, p.34).

Aos olhos do pesquisador, apoiado na metodologia utilizada, o esse DSC explicita uma Ancoragem pautada na assunção de que "professor tem de dar bom exemplo", cultura impressa no ideário desse profissional e marcadamente explícita, principalmente, naqueles de prática mais madura.

Sobre esse aspecto ainda, vale destacar que o professor, em seu ambiente de trabalho e fora dele, estabelece relação de subjetividade com seus alunos, que podem construir um ideário duradouro. Muito frequentemente, afirma Gonzalez Rey (1995), as verbalizações trazem a intencionalidade do sujeito de forma objetiva e clara, mas tanto nas comunicações verbais como nas não verbais existirão indicadores que conduzem a interpretações de uma mensagem e que aparecem como elemento importante na constituição subjetiva. Um processo constante dessa constituição da subjetividade se estabelece a partir da comunicação em vários níveis e dimensões, alcançando marcas implícitas diversas e únicas.

Com isso, pensamos ser importante aprofundar o olhar nas relações sociais, com a intenção de reduzir o impacto criado na atuação dos professores.

Outra preocupação de real expressão também foi destacada ao longo dos discursos, e diz respeito a gestantes e filhos de fumantes:

Ah, com certeza. Filhos de mães fumantes têm sérios problemas. Só pelo fato de nascer de uma mãe fumante... O cigarro afeta muitos, principalmente a gestante. E a gente vê muito. Muitas mulheres gestantes fumando e isso prejudica demais o feto...Ou a mãe que fuma e tá sempre com o filho no colo. Querendo ou não, de uma forma ou de outra, tá sempre afetando...

O prejuízo do fumo na gestação vem sendo largamente apontado, e pesquisas em todo o mundo, já abordadas aqui, mostraram que fumantes passivos, especialmente 
crianças, expostos à poluição tabagista de seus pais apresentam riscos de morbidade respiratória e o chamado "chiado do peito" (BAKOULA e col., 1995).

As crianças fumantes passivas também apresentam maior probabilidade de contrair infecções do trato respiratório superior e inferior. Além disso, há maior possibilidade de apresentar infecções no ouvido médio, que podem acarretar a redução da audição (ROSEMBERG, 1987).

Ainda sobre pais fumantes, STEWIEN (1979) já apontava que eles têm forte influência sobre os filhos. A autora destacou a existência da proporção duas vezes maior de adolescentes fumantes cujos pais fumam.

$\mathrm{Na}$ análise das respostas à pergunta: "E o aluno fumante, como é isto para você?", observamos uma diversidade de idéias, fruto talvez da insegurança, da falta de apoio ou ainda do despreparo do professor frente à indicação científica dos inúmeros problemas de saúde decorrentes do fumo.

O consumo do cigarro na escola é muitas vezes visto como sem importância, sendo até mesmo apoiado pelas famílias, já que o aluno traz esse hábito de casa, como relatado a seguir:

...O aluno fumante eu acredito que ele normalmente traz essa bagagem de casa. Porque numa casa onde ninguém fuma a probabilidade de você, do filho não fumar é maior do que numa casa onde existe fumante... Dar conselho, nós como educadores, damos conselho tudo, mas infelizmente já vem de casa.

... Agora, se os pais sabem e autorizam, se dão dinheiro para comprar o cigarro, isso aí é responsabilidade deles...

Outras vezes, o professor se sente intimidado pela circunstância de o aluno ser um adulto e desconsidera a proibição legal desse hábito dentro da escola:

Atrapalha, porque... o vício, eu vejo assim que muitas vezes você percebe que ele tem aquela necessidade de fumar, você tem que liberar o aluno pra sair da sala de aula ... ir pra algum lugar pra ele poder fumar. Mesmo não sendo permitido na escola, a 
gente sabe que, no período noturno, você trabalha com EJA, você trabalha com adulto, né?

Você não tem como podar isso, então você tem que saber administrar essa situação... sem fumar, ele fica inquieto, não consegue prestar atenção na aula, o rendimento também, não adianta em nada...

Com contradições e revelações da presença de aluno fumante no pátio, novamente a situação de impunidade se torna evidente. E expressando pouca disposição para contestar, o professor contabiliza o aluno como único prejudicado, como no relato a seguir:

Eu ainda não... me deparei com aluno fumante. Tenho 8 anos de escola e não me deparei assim em sala de aula... se eles fumam aí fora, nunca, nunca me deparei com nenhum.

Eu nem vejo por aqui. Aqui é tão proibido que... a gente... dizem que na parte de noite, EJA tem muita aula, aí tem aluno fumante, mas eles nunca fumaram na minha frente. É sempre no pátio, longe. Agora, minha opinião, sei lá, ele tá afetando a saúde dele.

E ainda mais, como hoje em dia nos deparamos com a presença de drogas consideradas muito mais pesadas rondando o ambiente escolar, o professor se utiliza desse fato como desculpa para não se preocupar:

...É... eu acho que é um problema pequeno perto de outros problemas que nós temos... ...Ah, hoje fica difícil falar só do cigarro, porque eu tenho outras, outras grandes preocupações. Se tivesse que colocar pra você com relação às drogas em geral, o cigarro é o que menos me preocupa... o fumar deles não é só cigarro...

Esse depoimento revela uma tradução da banalização do consumo de cigarros, já que o indica como um problema pequeno frente a outros. Desconsidera vários estudos que apontam a nicotina tão ativa quanto a heroína, cocaína e álcool. Não 
reconhece que a maioria dos tabagistas começa a fumar na adolescência, sendo que, segundo US Departament of Health and Human Services (1994), se mantido longe do tabagismo nessa idade, dificilmente se tornará um fumante. Nem tão pouco considera que o fumo também tem sido descrito como a "droga de entrada" (gateway drug), isto é, que a maioria dos jovens que usam drogas pesadas, como maconha, cocaína ou heroína, teve experiência prévia com o tabagismo (Silva apud MS/OPAS, 2004, p.37).

Com isso, o jovem fica submetido à sua própria sorte, como pode ser observado no depoimento abaixo, deixando o professor de cumprir seu papel de educador e formador para o qual foi confiado ao se colocar no exercício de sua profissão.

...Eu acho muito pessoal. Acho que cada um escolhe o caminho que ele quer, né? O aluno sendo maior de idade eu acho que ele já é dono do seu... caminho. Alertar a gente alerta, mas se ele acha legal pra aparecer pros outros... Eu acho que cada um tem que ter a sua responsabilidade. Se ele acha que fumar faz bem pra ele, quem sou eu pra impedi-lo...

Permitir que esse profissional se conscientize do potencial do seu trabalho nos parece muito relevante para melhorar sua atuação na escola. Também porque, segundo Freire (1996 p.135) "é preciso saber ou abrir-se à realidade desses alunos com quem compartilha a atividade pedagógica para diminuir a distância que me separa de suas condições negativas de vida"...

No entanto, para quase $40 \%$ dos professores a consciência do perigo da adolescência é explicitada:

...O vício começa justamente na adolescência, que é uma fase onde eles estão é ... a todo momento querendo se auto-afirmar. Querendo se posicionar como adultos, antes, antes mesmo de se tornarem adultos.

Muitas pessoas que eu conheço tiveram iniciação aí... na adolescência. Eu acho que aqui é a maior incidência... do início do fumo, é na adolescência mesmo. 
Como adolescente, eu entendo, é curiosidade, o cara quer transgredir regras. Ele muitas vezes ele fuma pra aparecer...

E a preocupação com o vício, principalmente por ser fumante, aparece:

Ó, como eu sou fumante, o aluno fumante pra mim me preocupa bastante. Porque os fumantes normalmente são aqueles adolescentes no nível de 14, 15 anos de idade. Então me preocupa bastante, inclusive eu comento com eles: olha eu sou fumante e não é nada agradável. Depois que você entrou no vício é muito complicado você sair dele. Então, cara, reflete, é isso mesmo que você quer? Pra quê? Não vai resolver seu problema.

Novamente, se mostra visível a consciência da dependência química do cigarro caracterizada como doença (CID-10) pela OMS, que, desde 1992, catalogou o tabagismo "como uma desordem mental e de comportamento em razão da síndrome da dependência à nicotina".

O compromisso com a própria consciência também se manifesta, como pode ser comprovado no DSC abaixo:

E sempre eu falo... desde que eu sou professora eu aconselho. Que pode causar câncer ou problema no pulmão.

A gente orienta. Fazemos sempre palestras, trabalhos sobre... como drogas, que é pra não fumar. Brinco com eles. Fumar dá câncer, fumar da impotência, fumar dá outras doenças, pra vê se...

A dificuldade em fazer a conscientização também não deixou de ser explicitada, novamente ganhando destaque a questão da moral: 
...é que é muito difícil você fazer a... conscientização, eu acho. Porque se esbarra numa série de coisas, no aspecto inclusive de eles não acharem que você... eles te relacionam como uma coisa mais brega, de tá dando lição de moral...

Para auxiliar o professor em seu trabalho de conscientização ou até mesmo proporcionar-lhe uma reflexão dessa ordem, parece-nos evidente a necessidade de aproximação das pesquisas científicas e seus enfoques, no sentido de transformar a visão desse profissional. Em sua docência, o professor tem contato diário com jovens que, ao saírem da escola, têm uma vida ativa, não só pela variedade de ambientes a que se expõe, como também pela facilidade com que se comunicam, fazendo da internet seu território de "trocas" e representações.

Portanto, contar com sua militância segura e esclarecida dentro da escola, que, há tempos, passou a ser espaço privilegiado para ações de promoção da saúde, não nos parece exagero.

O quarto questionamento: "Você já participou de alguma atividade ligada ao tabagismo na escola? Fale um pouco sobre isso" enfocou a ocorrência de "acontecimentos" com ênfase ao tabagismo que, possivelmente, marcaram a vida do professor.

A alta porcentagem de respostas negativas a esse questionamento, aproximadamente $60 \%$ dos entrevistados (Figura 12), mostra a falta de atenção às questões de tabagismo nas escolas aqui em foco. E ao analisar os mesmos depoimentos, não encontramos o professor sendo definitivamente o principal entrave para ações dessa natureza.

Se devidamente apoiado, o professor passaria da conscientização dos malefícios para outras abordagens, desde que estivesse desempenhando seu papel não de forma solitária, mas juntamente com seus pares e sob orientação de um órgão competente:

... às vezes você bate no preconceito dos pais que não admitem este tipo de diálogo de comportamento... fica muito complicado você sozinho tentar fazer... A não ser que surja um projeto na escola que você... como se diz, você tenha respaldo da Diretoria de Ensino, da Secretaria de Educação, que possa te fornecer material... 
Vale ressaltar aqui que momentos de reflexão coletiva formam comunidades de aprendizagem, com professores reflexivos que se apóiam e se estimulam mutuamente.

A reflexão, portanto, permite a valorização da profissão docente, dos saberes dos professores, do trabalho coletivo para formação contínua e permite que se projete a sociedade que se quer ter (PIMENTA, 2005).

Apoiado nessa prática acreditamos que esses professores poderão buscar uma aproximação maior de sua atividade pedagógica com as ações de controle do tabagismo na escola, resultando assim em novas formas de o alunado pensar.

Discursos sobre ações pontuais voltados ao tabagismo também foram evidenciados em aproximadamente $20 \%$ dos depoimentos (figura 12). Pelos relatos, essas ações nos pareceram muito tímidas e presentes em momentos que não se constituíam como parte formal do projeto pedagógico das escolas:

...Uma vez na escola pública, no noturno, nós fizemos um trabalho, acho que era uma coisa assim, Semana da Saúde, e no HTPC, foram feitos sorteios. Cada professor tinha que falar de um assunto, para não massificar a situação e ficar uma coisa maçante pro aluno, cada um pegou um assunto diferente. E o meu foi é... um, foi o tabagismo e a outra foi sobre...gravidez na adolescência...

Outra manifestação de ação pontual também foi traduzida pelo relato de uma intervenção do Instituto do Coração (INCOR) de São Paulo. Essa instituição pretendia estabelecer hábitos saudáveis com foco no controle de doenças cardiovasculares em adolescentes e trazia o tabagismo como um dos aspectos a serem abordados:

...Aqui nós tivemos atividades que... tive um projeto que é do INCOR e...vamos dizer assim de todas as atividades que a gente fez que seria o álcool, ... a alimentação $e$ o fumo é... a gente mostrou algumas experiências pra eles ficarem conscientes do problema que o cigarro causa ... 
Ainda tratando do questionamento na participação em atividades ligadas ao tabagismo na escola, apenas um professor entrevistado manifestou não ter participado, mas ter explicitamente vontade de participar:

...Ainda não participei, mas eu teria vontade de participar com os professores, com os próprios alunos, conscientizando sobre o tabagismo... Eu sei que isso não é possivel, fazer a cabeça de uma pessoa assim, mas eu acho legal trabalhar o tabagismo pra alertar o que que o cigarro... o mal que o cigarro tá trazendo pra ele. Este seria um trabalho interessante que eu gostaria de estar fazendo.

Envolver o professor nessa proposta nos parece de fundamental importância, porque não apenas sua reflexão como atributo do ser humano traz em si fatores agregadores ao controle do tabagismo e seus malefícios, como também poderá desencadear uma melhor compreensão do trabalho docente. E, ainda mais, se constituir em um movimento de produção do saber docente sobre sua prática, pois pesquisas revelaram que, pautada em uma ação educativa de caráter pedagógico, uma maior aproximação da escola às necessidades do alunado reverte de forma positiva na adoção de mudanças de hábitos.

A quinta pergunta: "Como poderia ser abordada a questão do tabagismo pelas escolas?" evidenciou que em $90 \%$ dos discursos a preocupação em oferecer atenção ao assunto no ambiente escolar é fato. A começar alertando pelos prejuízos à saúde ou ainda ao "bolso" e trazendo uma visão que ora responsabiliza diretamente as disciplinas de Biologia ou Ciências ora abre a discussão para um trabalho multidisciplinar.

A abordagem apoiada por especialistas, com palestras, conferências e vídeos, foi apontada como auxiliar do trabalho docente de uma forma interessante. Segundo alguns professores, dessa forma ela poderia substituir momentos de teoria muito abstrata para os alunos, que permeiam os conteúdos dos componentes curriculares. Esses profissionais também poderiam suprir a falta de material de apoio, como comprovado no DSC abaixo: 
...Porque tem muitas matérias, muitas disciplinas. No caso, que os alunos... ficam meio que, como que eu vou dizer..., pra eles é tudo muito abstrato. Então eu acho que nesse tempo que os alunos têm de abstração em determinadas matérias é onde deveria entrar o especialista, como se fosse um psicólogo e dar aulas pra eles. Mostrar o caminho correto... Com palestras, com... testemunhos, pegar pessoas que fumaram muito e que pararam...

... mas eu ainda sinto falta de material pra trabalhar, porque às vezes eu vejo uns cartazes muito legais. Inclusive tem um que tem todas as substâncias que tem no cigarro, mas é de difícil acesso. Não sei se tem disponível por aí, não sei se também tem toda uma jogada das grandes marcas que eles não querem que seja mesmo visto... falta um pouco mais desse aprofundamento de substância, do mal que pode fazer pro indivíduo.

A mídia também aparece como recurso de pesquisa e discussão para desenvolvimento de trabalhos com os alunos; porém, prontamente é destacada a suspeita da atuação da indústria no controle da divulgação dos prejuízos que o cigarro pode trazer (como mostrado no DSC acima).

A redução da propaganda do cigarro nos meios de comunicação também teve seu reconhecimento:

Olha, começando pelos meios de comunicação. É... que às vezes a gente vê propagandas em televisão ou outdoors, revistas. Então eu acho que a gente poderia começar a abordagem pelos meios de comunicação, pra eles observarem o que a mídia passa. Se bem que eu acredito que isso já tá diminuindo bastante porque a gente vê que em novela, os atores não fumam tanto, né?

A abordagem do tema tabagismo através de projetos mais dinâmicos e envolventes aparece aqui como alternativa para conhecer melhor o alunado: 
... Eu acho que em forma de projeto... Envolvendo todos os professores, envolvendo a coordenação tudo ... e integrado a toda a turma.

... é melhor do que só você falar em livro. No livro comenta, você lê o assunto, faz algumas experiências. Mas o projeto sempre é mais dinâmico. Sempre envolve. E o projeto é mais longo.

E daí você conhece melhor o aluno e tem tempo de retornar pra você algumas coisas que aquelas aulas mais curtas não tem.

Outros professores sugeriram que a abordagem do tema deveria envolver o aluno de forma diferente:

É... eu acho que deveria ser feita de uma forma diferente do que a gente simplesmente dizer que faz mal a saúde. É... eu acho que faz parte, mas esse discurso, eu acho que não cola com eles.

Ou ainda, com uma visão mais ampla, essa abordagem ser diversificada, atrelada à proposta pedagógica da escola e ao seu público:

Olha... Depende da escola, depende da... classe. Tem escolas que se poderia falar de uma maneira mais... como se diz, aberta.. Outra já de maneira mais restrita. Entendeu? Seria de uma maneira mais é... repressora. Porque depende da... do nível do aluno, do... da origem, da educação que ele teve.

Na riqueza de depoimentos colhidos sobre o tabagismo nas escolas, também foi destacada a importância de se oferecer uma maior variabilidade de atividades ligadas à arte, aos esportes, à música ou outras modalidades. Essa proposta parece buscar o envolvimento dos jovens e desviar sua atenção do consumo de cigarros na escola: 
É... eu tenho a idéia de que quando você oferece é... outras soluções, outras coisas mais interessantes, como a possibilidade de apreciar arte, de fazer um esporte, de tá ... movimentando todos eles de uma forma mais ...mais produtiva mesmo e mais gostosa, eu acho que essa curiosidade por esse cigarro, por outras coisas ficam em segundo plano. Então, é uma coisa assim de tentar suprir alguma coisa que tá faltando, é... assim como eu acho que o cigarro é distração, muitas vezes pode ser assim uma ocupação, pode ser substituído por uma ocupação um pouco mais inteligente, uma coisa mais interessante...

No DSC acima podemos observar o desprendimento às ações de transmissão de informação seguidas por modelos educativos passivos para um protagonismo do jovem. Segundo MOREIRA e col. (2006), de fato, é importante que as atividades variem conforme os interesses da população a que se destinam. Modelos desse tipo têm contribuído muito no controle de drogas mais pesadas e podem estar associados a propostas de "redução de danos", atendendo a uma política de saúde voltada à redução dos prejuízos de natureza biológica e social, pautada no respeito ao indivíduo.

Em contrapartida a essa concepção, em 5\% dos depoimentos foi sugerida uma proibição e punição irrestrita a todos que não fizerem cumprir a lei, já que aconselhamento "não funciona":

...O que eu entendi até agora é que aconselhamento não funciona. É... essas campanhas muito, vamos dizer assim, entre aspas, informativas não funciona."

"Pra mim tinha que ser uma lei, assim pau, pau pedra. Não pode fumar aqui, acabou e pronto. E... ter alguma punição pro cara que fuma. Advertências, tinha que ser considerada uma falta disciplinar grave. Eu acho. Porque falar e aconselhar e isso aí eu nunca vi eficiência em nada... Ter punição pro cara que fuma. Começando pelos professores. Professor, funcionário... Aqui houve um caso absurdo que eu achei uma... festa junina, os professores que estavam na porta atendendo os pais fumando. Com o cigarro, cinzeiro, sei lá, começa por aí. 
Outra pequena porcentagem da amostra pesquisada destaca o papel dos pais no controle do tabagismo, deixando assim de subjugar a escola como única responsável nessa questão:

Ah, eu acredito que a escola sozinha não pode fazer nada... se você não tiver os pais junto com você na escola pra tentar resolver a questão, conscientizando, mostrando pra eles que o exemplo deles conta muito. Pedindo pra eles observarem as crianças nessa adolescência...

A adolescência aparece aqui como momento de maior atenção reforçando inúmeras pesquisas que a apontam como fase de risco para doenças sexualmente transmissíveis, gravidez não planejada e alta vulnerabilidade para acidentes que poderão engrossar os índices de violência e morte.

Segundo SEIXAS (1999 apud PINHO et al., 2002), uma rede intrincada de fatores estruturais e comportamentais permite dizer que esses jovens estão expostos a uma diversidade de vulnerabilidades, e, portanto, não só o cigarro exige atenção como também a violência conjunta decorrente de agressões e acidentes de trânsito.

Quanto à abordagem da sexta pergunta: "E sobre projetos relacionados ao tabagismo na escola, o que você acha disto?”, buscamos uma aproximação maior à visão do professor frente à metodologia de projetos que, possivelmente, não tivesse sido evidenciada anteriormente.

O DSC construído a partir dos depoimentos de mais de $60 \%$ dos entrevistados expressou interesse em trabalhar com projetos, como pode ser mostrado a seguir:

Eu acho interessante e seria benéfico... Porque o projeto, você pode desenvolver de diversas maneiras. Em forma de teatro, não é assim? Em forma de dança. E é uma maneira de chamar a atenção no palavreado deles. Naquilo que eles gostam de fazer. Porque você coloca aí um cara falando, falando e ele escutando. Não adianta, você sabe que aluno não escuta mesmo, né? Então, trabalhar em projeto eu acho legal... 
Tinha que ser por interdisciplinaridade, todos os professores entrarem, todas as matérias, não só o ensino fundamental II, mas desde o pré...

O protagonismo dos alunos, a autonomia do professor e a interdisciplinaridade no desenvolvimento dos projetos aclamados pelos professores nos parecem importantes para conduzir uma aprendizagem ativa e compatível com uma sociedade em rede que absorve um fluxo permanente de informações.

Assim, a cultura de hoje passaria a despertar o grupo para uma reflexão que poderia ir muito além dos muros da escola e se transformar na formação de cidadãos ativos que poderão construir uma sociedade sintonizada com a revalorização da vida.

Uma reforma do pensamento dos educadores e uma melhoria dessa prática pedagógica precisariam estar pautadas, segundo MORIN (2001), numa aprendizagem da re-ligação, da complexidade e do amor.

Para uma parcela do público pesquisado, a prática desse pressuposto teórico estaria associada a um apoio das políticas públicas revertidas em recursos ao alunado:

...O governo devia investir mais nesses projetos de saúde. Porque só os livros, lousa e giz não resolvem...

...Se falam muito em cursos para os professores, reunião pra isso, reunião pra aquilo, não adianta. Eu acho que a base pra se educar é o aluno. O tanto de dinheiro que se investe nos cursos pra professores destina-se uma parte pra esse tipo de coisa...

É importante destacar que idéias como afeto, prazer, amizade no contexto escolar podem ser armadilhas e "recursos pedagógicos" que, muitas vezes, são utilizados como "moeda de troca" para atitudes de respeito. Não queremos aqui dizer que não seja necessária uma aproximação dos professores com seus alunos, também porque a proximidade traz sentido aos conteúdos e mantém um canal de comunicação de real relevância. No entanto, queremos sim chamar a atenção para que não haja uma 
construção apenas pelo viés afetivo, ancorado na prática de que só merece nosso respeito aquele que mantém uma relação simétrica conosco.

Segundo SAYÃO ( SAYÃO E AQUINO, 2004, p.75), “o verdadeiro papel da escola deveria ser o de se constituir como lugar para o aluno aprender que é possível estabelecer e manter relações impessoais justas". Respeitar os outros pelo fato de não serem semelhantes, promovendo assim o surpreendente aprendizado democrático.

A incredulidade na Pedagogia do Afeto, idealizada por CHALITA (2001) e proclamada por Diretorias de Ensino na gestão do Governo Alckmin, foi também outro aspecto destacado. Ela aparece traduzida pelo seu insucesso no apoio do trabalho docente:

...Porque não adianta falar que tem que ter pedagogia do afeto, se a criança não sabe o que é afeto e se o professor não tem como distribuir esse afeto. Uma pessoa que fica das sete às cinco da tarde em sala de aula, é complicado. E o que acontece é que nós estamos aí de frente com os adolescentes, e a gente percebe que eles estão se perdendo, se acabando e a gente tem muito pouco para fazer. Por que você exige conteúdo, se exige uma série de coisa, sendo que deveria mudar um pouco isso daí, conscientizar, conversar, orientar... só caderno, livro, giz e lousa não... ficou provado que não tá dando certo.

Nesse DSC já se evidencia a falta de tempo do professor para se preparar e exercer dignamente sua função na escola. A baixa remuneração impõe jornada integral de trabalho, o que torna impossível não só a busca de aprofundamento teórico de sua prática, como também o reconhecimento do seu alunado.

Em contrapartida, não só o tempo como complicador na preparação das aulas foi destacado como também a própria imposição de projetos.

A constância desse tipo de proposta na escola, sem que o professor seja solicitado para autoria, discussão da relevância do tema ou previsão de prazos tem incomodado esse profissional e pode ser destacado pelos DSCs a seguir: 
Se o projeto trouxer um material e também ajudar o professor a ter mais informações sobre isso, eu acho válido. Por muitas vezes os projetos chegam à escola e assim você tem que fazer aplicação num espaço muito curto de tempo".

“O professor não tem tempo pra preparação adequada e quando você vai fazer a realização do projeto ele fica com aqueles buracos e você tem a impressão que o projeto não deu certo...

...E os projetos muitas vezes vêm de cima pra baixo e nós professores e alunos... muitas vezes não conseguem realizar os projetos porque não é a realidade que eles imaginam ... vem lá o projeto bonitinho, com objetivo tal, tal, tal e num tempo pra ser desenvolvido e que ele não consegue ser desenvolvido, ou então porque não tem como desenvolver.

Tal dia a gente vai fazer isso, aí a gente não consegue fazer, ou porque... é... não entra na cabecinha deles que isso pode ser prejudicial pra eles. Então existe uma diferença, um abismo entre quem faz o projeto, quem planeja tudo e a realização dele, $e$ até dar certo ou não.

O insucesso nas abordagens impostas por políticas públicas está assentado na elaboração de propostas teóricas que raramente se dispõem a uma real aproximação da prática na sala de aula. O pensar é muito diferente do fazer. E tal fato é tão real que a própria proposta pedagógica conduzida pelos Parâmetros Curriculares Nacionais (PCNs) propõe o desenvolvimento de competências e habilidades que propiciem ao aluno condições para "o saber fazer".

Para o professor também é necessária a convivência na elaboração de propostas pedagógicas, pois essa aproximação resulta na reflexão e no desenvolvimento de habilidades para melhor conduzir o trabalho em sala de aula. LEONTIEV (apud PIMENTA E GHEDIN, 2005, p. 75) reforça esse fato quando comenta que a reflexão mental nos seres humanos está ligada ao processo da atividade orientada para um objetivo e mediada por esse processo. 
Sobre esse aspecto, também BRUNER (2001, p. 146) destaca que:

... a mente humana constitui uma extensão das mãos e das ferramentas que você utiliza e das funções às quais você aplica... Freqüentemente sabemos fazer as coisas muito antes de conseguirmos explicar conceitualmente o que estamos fazendo ou, normalmente, por que deveríamos estar fazendo-as... O trabalho ou a atividade, ou, de maneira geral, a prática, fornece um protótipo de cultura.

Além disso, as relações que se estabelecem em sala de aula atingem um grau de subjetividade tal que não basta se apoiar no domínio de conteúdos a serem ministrados ou na praticidade da aplicação de um modelo de aula. Se isso fosse suficiente, não haveria necessidade de realizar intervenções disciplinares em apoio a um professor que, apesar de seu elevado conhecimento sobre o assunto ou idealismo profissional, não encontra espaço para ministrar sua aula.

Em concordância com essa argumentação, ainda poderíamos citar o caso de professores eventuais, que, em substituição ao professor cuja aula foi atribuída oficialmente, não conseguem ser "aceitos" pelo alunado, mesmo dando continuidade a um trabalho pautado na atividade formal proposto pelo projeto pedagógico da escola.

A sala de aula é um mosaico de situações decorrentes muito mais da bagagem que o aluno traz para dentro da escola do que da intenção proclamada para a aula arduamente pesquisada ou discutida pelo professor com seus pares em reuniões de planejamento e Hora de Trabalho Pedagógico Coletivo (HTPC).

No entanto, não queremos dizer aqui que, em decorrência desse fato, seria dispensável o domínio sobre os conteúdos ou o aprofundamento em discussões da prática do professor para garantir o aprendizado do seu aluno e melhorar as suas condições de trabalho.

Pelo contrário, vemos aqui um sinalizador da necessidade de implementação do processo da prática do professor reflexivo, que, segundo LIBÂNEO (apud PIMENTA E GHEDIN op cit, p. 76): 
...vem trazendo aportes valiosos para a pesquisa como a recusa do professor meramente técnico, a afirmação da prática docente como uma ação consciente e deliberada, a correspondência entre teoria e prática nas ações cotidianas, a aceitação da existência de pressupostos interpretativos e valorativos na atuação e nas decisões profissionais.

Porém, devemos considerar também que, de acordo com CONTRERAS (1997), o professorado tende a limitar seu mundo de ação e reflexão à aula e ao contexto mais imediato, não conseguindo ver assim os condicionantes estruturais do seu trabalho, da sua cultura e das formas de sociabilização. Esse fato leva-nos a sentir a necessidade do apoio de uma teoria crítica que permita ao professor ampliar sua visão e praticar uma reflexividade emancipatória que vai gerar uma autonomia intelectual e política.

Construir conhecimento e desenvolver competências implica sempre em adotar uma reflexividade, também porque a escola é lugar da formação da razão crítica, do raciocínio, da análise e do julgamento.

O professor é também um profissional que necessita encontrar espaço para reelaborar seus mecanismos de atuação e resiliência. Só assim poderá manter o equilíbrio de suas ações e afastar a licença saúde que, muitas vezes, aparece em decorrência dos efeitos cumulativos do estresse e da Síndrome de Burnout. Esta expressão, criada por Freudenberger (1974), foi utilizada para descrever uma síndrome composta por exaustão, desilusão e isolamento em trabalhadores da saúde mental, também pode ser caracterizada como uma exaustão física e emocional e geralmente é reconhecida pela ausência de alguns fatores motivacionais: energia, alegria, entusiasmo, satisfação, interesse, vontade, sonhos para a vida, idéias, concentração, autoconfiança e humor.

A indisciplina decorrente do despreparo e da falta de compreensão dos alunos frente às necessidades de um ensino de qualidade constitui-se em um dos fatores que fortemente concorrem para o aparecimento dessa enfermidade entre professores.

É certo que, para trabalharmos em escola, é fundamental que sejamos generosos, já que se oferta muito e não se pode contar com o fruto imediato do nosso investimento. 
O fato é que isso se torna mais um fator de desgaste do professor no exercício de sua docência, já que ele precisa sustentar uma posição que, muitas vezes, não é reconhecida pelo aluno como tendo sentido, sendo então rejeitada por este.

Os determinantes políticos externos e internos, apoiados na prática de ensino, na gestão, na convivência, exigem uma reflexividade comunitária e compartilhada que reúna os esforços para instaurar nas escolas uma construção de significados e entendimentos a partir das diferenças e da busca de valores que auxiliem o professor nesse contexto.

Além disso, há também professores que estão sempre "remando contra a maré", anônimos, lutando contra um anacronismo burocrático que não permite que se consiga manter coisas tão simples como as salas-ambientes. Esta iniciativa já conta com destaque reconhecido em escolas públicas do tipo Escola da Ponte, da cidade do Porto em Portugal.

Somado a isso, diretores e coordenadores acabam constantemente trocando de equipes a cada início de ano, resultando em um desperdício histórico de ações que, com muito empenho, já se encontravam em fase de resultados.

Retomando a proposta dos projetos de tabagismo, outro aspecto levantado diz respeito à superlotação das classes, o que inviabiliza a aprendizagem com práticas mais lúdicas e que permitam a construção do conhecimento, resguardando a autonomia do aluno:

Eu acredito que você pode dar voz pra eles, eu acho muito importante. Eu já tentei esse caminho e vi que o resultado é muito melhor.

É como na escola particular, que você trabalha muito mais isso, né? De fazer seminário, fazer eles pesquisarem. Eu era cobrada muito nas escolas que eu trabalhei essa coisa do aluno pesquisar. E quando eu vinha, eu tinha que lincar isso, fechar o assunto. A fala deles era muito mais bem elaborada, que eu tentasse fechar isso na cabeça deles. 
Agora, na escola pública, por questão de superlotação na sala de aula, você vai tentar fazer um debate. Nem todos tão centrados naquele que tá expondo ali na frente, né? Dispersa muito.

Em meio aos depoimentos, foi novamente destacada a importância do envolvimento dos pais e ainda de atingir de forma mais ampla toda a sociedade para promover a eficiência da ação:

...Eu acredito que os projetos são válidos. Todo o que vem pra somar, pra ajudar, é válido, vale a pena investir nisso, mas eu não acredito também no resultado. Porque nossa realidade, ela é muito cruel nesse sentido. Não sei se adiantaria um trabalho feito apenas com aluno, só com aluno, mas no meu ponto de vista deveria ser feita envolvendo família, escola, comunidade, a participação da sociedade como um todo, porque ação individualizada, por projetos, em minha opinião não resolve...

Uma abordagem diferente sobre o assunto, que foge da prática tradicional, foi novamente apontada e complementada pela sugestão da ênfase na estética, já que na adolescência a vaidade muitas vezes ocupa considerável espaço no ideário jovem:

...Ah, eu acho que é válido. Eu acho que a escola, essa coisa educadora mais ampla, é... entra isso também. Mas é o que eu te falei, eu acho que a gente tem que pensar numa outra linguagem. Não aquela coisa muito tradicional, porque eles vão achar que tão fazendo um trabalho como qualquer outro trabalho Aí eles fazem lá, um cartaz e colam umas coisas e depois eles vão fumando pra casa. Não adianta nada.

...e legal pegar uma pessoa com dentes perfeitos, bonitos, como abre um sorrisão e a pessoa depois de 30 anos, precisando de tratamento de dente. Tudo amarelo, bem diferente... Tem que mostrar pra molecada como vai ficar depois. Praticamente. 
O jovem tem que pegar por outro lado. $O$ apelo deles, como eles são muito visuais. Então você deve montar um projeto visual mesmo, esteticamente, é isso que eu quero dizer, esteticamente. Não só pra sua saúde...

É interessante notar ainda que, em meio às respostas de atenção aos problemas que permeiam o trabalho de controle ao tabagismo nas escolas, não deixou de aparecer também a vontade de voltar o olhar para aquele aluno que se destaca com exemplo de comportamento:

... A gente tem que cobrar, mas também tem que elogiar. E eu sempre falo, a gente perde muito tempo falando daquele que dá problema, esse daí a gente deve orientar, mas também temos que enaltecer os excelentes, se não fuma, nós temos que fazer um trabalho ótimo pra ele nunca fumar.

Esse depoimento se apresenta também em concordância com a visão positiva orientadora da promoção de saúde, que, segundo LEFREVE e LEFREVE (2004), seria uma visão apontada para a percepção ampliada, integrada, complexa, intersetorial, relacionando saúde a meio ambiente, ao modo de produção, estilo de vida entre outros. Sendo assim, promoção de saúde não é responsabilidade exclusiva do setor saúde.

No entanto, também observamos nos discursos o descrédito na metodologia dos projetos na escola como prática assertiva e até mesmo o destaque ao tabagismo como hábito menos prejudicial que outros:

É... Eu não acredito na eficiência disso, viu. Eu acho que...informação todo mundo tem. O próprio maço de cigarro vem escrito, entendeu?... O cara que fuma, fuma porque ele quer fumar mesmo. Eu acho que não funciona. Esse tipo de coisa acaba sendo uma propaganda para aumentar o tabagismo na escola. 
Não sei se tem a necessidade. Acho que não tem a necessidade. Eu acho que é assim, no máximo pode ser trabalhado as conseqüências. Não é um vício tão grave... como drogas. Eu acho que é mais leve, mas que prejudica também.

O tabagismo do professor novamente mostrou-se como fator limitante à sua atuação contra essa prática entre seus alunos:

...Olha, eu sou suspeita. Como eu vou fazer um projeto pra não fumar se eu fumo? Eu jamais poderia fazer isso. Porque... o que eu vou falar? Não fumem que faz mal? Eu acho que o aluno...É aquilo, faça o que eu digo mas não faça o que eu faço. Eu acho que não é por aí. Aí fica desacreditável, professor fazer isso.

Finalizando a entrevista, ao formular a questão 7 "Você quer falar mais alguma coisa?" procuramos investigar possíveis lacunas de expressão do pensamento dos professores no decorrer das respostas, mesmo que algumas vezes iniciadas com expressões do tipo: "Não. Tá tranqüilo" ou "No momento não". Essas colocações em mais de $80 \%$ dos professores foram seguidas de uma continuidade espontânea das falas, sem nenhuma intervenção do pesquisador.

Através desses relatos espontâneos das idéias sobre o assunto tabagismo, procuramos oferecer ao entrevistado a oportunidade de minimizar sua ansiedade não manifesta. Ao expressar-se à vontade, o professor pôde discursar sem se sentir cumprindo o compromisso de responder a um questionamento específico.

A pergunta $\mathrm{n}^{\circ} 7$, portanto, buscou permitir essa expressividade do professor, revelando que algumas idéias que permearam os discursos foram novamente destacadas ou enfatizadas. Entre elas, a concordância da necessidade do tema na escola ou ainda preocupações com alianças sociais e parcerias, como pode ser observado nos discursos: 
Não. Tá tranqüilo, mas eu acho que deveria mesmo introduzir isso aí na escola. Porque eu trabalho de manhã com eles, com adolescentes.

A gente vê eles fumando aí no pátio e fica morrendo de dó. Porque de repente não tem quem explicar em casa...

...Eu acho que é uma mensagem que a gente tem pra mostrar, pra conter isso, esse impulso. Só que com uma preparação bem feita do professor. Se o projeto for bem estruturado, ele vale a pena ser aplicado na escola. E assim, seria interessante não só com relação ao tabagismo, seria interessante mais interação dos professores, com qualquer outra campanha, qualquer outro assunto, união dos professores pra poder trabalhar com isso."

"A gente tem grandes índices de usuário de drogas numa escola, então a gente poderia trabalhar todos os professores juntos...

Olha, eu achei interessante essa tua pergunta de projeto de tabagismo nas escolas porque eu leciono há tantos anos e eu nunca vi.

Quase 20 anos que eu dou aula, nunca vi campanhas assim...

...É, mas o que a gente percebe, eu vejo assim, que precisa uma aliança social, aí a coisa funcionaria bem. Por quê?

Você vai a um bar, em qualquer estabelecimento, uma criança compra cigarro, tranquilamente. Eu te digo porque, é proibido por lei, mas vendem...

Quanto à presença de projetos interdisciplinares ou transversais, AQUINO (in SAYÃO e AQUINO, 2004) já destacava que é muito difícil encontrar uma escola que conte com eles de forma a dar coesão e mais sentido ao alunado.

A complexidade do tema também foi explicitada em meio aos depoimentos espontâneos, devendo assim aproximar sua abordagem da comunidade local: 
Eu acho que o negócio do tabagismo como da bebida alcoólica também, do álcool é muito complexo isso. Entendeu?

Vai passar pelo problema psicológico também. Cada comunidade tem suas necessidades, tem que ser uma coisa voltada pra comunidade mesmo, o entorno, mas eu acho que se tem mais pra se falar, não ta esgotado esse assunto...

É um assunto que trabalha subjetividade individual, psíquica, social da pessoa, né? Então isso requer um certo cuidado. Porque, que têm efeitos têm. Malefícios, benefícios, sei lá. Físicos, psíquicos...

O discurso acima reconhece a subjetividade das relações que permeiam o dia-adia das escolas, trazendo consigo também a responsabilidade do professor sobre seu alunado.

O destaque para o prejuízo dos não-fumantes também aparece novamente como preocupação, e como um dos caminhos para a redução do consumo é apontado o aumento do preço do cigarro:

A única coisa que eu acho é que as pessoas que fumam deveriam ter consciência de que se o vício é delas, os outros não têm que ser afetado. Então, que você tem que saber se colocar na hora certa, a hora que tem que fumar. Que às vezes tem muita gente que não sabe.

Ah! Eu acho uma coisa que eu não falei e que você também não perguntou, eu acho que o cigarro tinha que ser muito caro. O preço barato é igual à pinga.

Porque que tem tanto bêbado? Porque a pinga é muito barata, sabe? Então o cigarro também é muito barato para o que eles têm na mão. Entendeu? Qualquer um real eles vão lá e compram, nem que for um ou dois cigarros entendeu? E compra 
picado, eles abrem o maço, vendem por 50 centavos, sei lá eu quanto que é, e aí a pessoa sempre tem como fumar, entendeu?

Para o professor fumante prevalece a desculpa de que outras substâncias também fazem mal à saúde e nada podem fazer, principalmente quando existe poluição atmosférica das grandes cidades:

Sei lá, eu sei que não é bom comer gordura, mas até quanto só o cigarro é prejudicial? Quanto aos males, eu até questiono. Não sei se é ignorância minha, mas até questiono mesmo. Quem fuma dois maços de cigarro por dia e mora no campo acho que fuma menos cigarro do que quem fuma nada e mora em São Paulo. Poluição atmosférica. Então é muito relativo até.

Ao longo de todo este trabalho de pesquisa, muitas revelações pessoais tornaram imperativas as buscas de caminhos que impedissem a aproximação das pessoas ao tabagismo, já que sua ação segundo DOLL et all (1950, 2005) é nefasta.

Depoimento do tipo: "É um vício, né. É um vício, eu sou consciente disso, mas não tenho vontade de largar. Eu gosto de fumar. É um prazer. Eu gosto de fumar, esse é o problema", destacado propositadamente e colhido em um momento que supostamente revelava ausência de qualquer desconforto com sua saúde, representou a expressão do pensamento de uma professora, ou de tantas outras, que se expõem aos ricos dos efeitos do consumo do tabaco. Traduzida por sedução, essa aproximação com o tabagismo precisa ser impedida a qualquer custo.

Frente ao sofrimento individual e familiar quando acometido por uma doença tabaco-relacionada, auxiliar o tabagista a encarar o desafio de parar deve ser objetivo de todos e, em especial, daqueles que podem fazer diferença aos adolescentes com tanta vida a percorrer.

Após exaustivas leituras e sensibilização com os discursos colhidos, passamos a fazer algumas considerações que, sem pretensão de esgotar tema tão complexo, fazem parte das conclusões deste trabalho. 


\section{Considerações Finais}

"Você tem de querer a mudança que quer ver no mundo" Mohandas Ghandi 
O longo período de descrédito e a impossibilidade de o professor expressar suas crenças de forma mais participativa nos processos de elaboração de políticas públicas educacionais têm transformado o ofício de educar em uma situação de desconforto.

Os resultados dessa forma de caminhar associados às mudanças sociais são expressos em atitudes de insegurança, individualismo e até mesmo de não-envolvimento do professor com aquele que deve ser o seu real foco de atenção, o aluno.

Se esses profissionais são criticados por resistirem às mudanças e persistirem em suas metodologias tradicionais, mesmo assim devem ser ouvidos e não combatidos. São atores sociais que, em contrapartida, apresentam extrema habilidade de adaptação a tantos contratempos intercorrentes do ambiente escolar.

A cada ano se mobilizam para atender escolas com públicos diferentes, gestores novos, materiais de apoio garimpados a "duras penas" e propostas pedagógicas que, no geral, mais parecem um mosaico de cores descombinadas.

Nesse cenário, o professor é convocado com freqüência para repartir tarefas em prol de uma ação participativa que mais se assemelha a um "coringa da carta do baralho" do que à valorização da sua habilidade em contribuir na construção das propostas pedagógicas da escola. Há tempo que a escola sofre com a escassez de seu quadro de funcionários, levando toda a equipe a assumir papéis trocados na busca de manter o andamento das atividades. Não causam estranheza mais ações do tipo "mutirão da limpeza na escola" para suprir a falta de funcionários e recuperar a higiene e o convívio escolar; quando não é o próprio professor que varre e limpa a sala para garantir um ambiente melhor ao colega que estará assumindo a classe durante o próximo turno. Não queremos adotar aqui apenas uma visão negativa desse "empreendedorismo", já que, algumas vezes, ele pode beneficiar o corpo discente em se tratando de questões ambientais e fazê-lo refletir sobre os excessos cometidos. Além disso, poderá também contribuir para uma formação mais abrangente em que, muitas vezes, atitudes de higiene não são valorizadas nem no ambiente familiar.

Porém, queremos destacar o exagero dessas ações em detrimento de outras estratégias que possam garantir o aprendizado formal do aluno. 
Se viver é transitar na incerteza, não é por isso que devemos caminhar sem planejamento. Dessa forma, corremos o risco de desviar totalmente do nosso propósito. O que acontece no cotidiano escolar tem de ser tomado como objetivo de instigação do pensamento, sendo que os conhecimentos teóricos solidamente construídos e reconstruídos não podem ser esquecidos.

É fato que a educação pública é determinante da qualidade que se obtém em outros campos. No ambiente social ela desperta o combate à pobreza, injustiça e desigualdade. No campo cultural permite que se formem novos hábitos e valores. $\mathrm{Na}$ questão ambiental busca que os indivíduos se conscientizem da necessidade da sustentabilidade e, seguindo a linha de pensamento aqui conduzida, promove a construção de uma cidadania ativa e crítica.

Somente os profissionais da educação, principalmente aqueles que se colocam à frente das ações, conhecem a fundo os problemas de cada escola, de cada comunidade e assim podem garantir o sucesso de propostas identificadas como prioritárias para o desenvolvimento daquela localidade. Além de saber "como e quando fazer", sua aproximação à elaboração de propostas em tempo real tornará seu envolvimento mais amoroso, mais responsável, permitindo até mesmo que ele saia da sua "área de conforto".

Ou seja, criar a possibilidade de estabelecer um diálogo entre o saber científico com o saber popular aqui expresso pelos discursos apresentados, entender que não se trata simplesmente de afirmar que esses profissionais não sabem o que dizer, mas sim que suas aspirações são, muitas vezes, improferíveis, é tentar reinventar as possibilidades emancipatórias. É se voltar à noção básica da promoção da saúde, a de "empowerment", termo que implica em "atribuir poderes a alguém, ou seja,"transferir poderes de decisão a pessoas e a equipes” ( MAXIMIANO, 2004, p.282), gerando o fortalecimento individual e coletivo dos indivíduos e garantindo, assim, a participação da comunidade na identificação de suas necessidades e na busca de soluções.

As estratégias e atividades de promoção da saúde dirigidas aos professores, alunos e suas famílias buscam exercer influência sobre os componentes comportamentais e culturais. Com isso, os hábitos sabidamente nocivos presentes no 
estilo de vida poderão ser repensados e substituídos por outros reconhecidos como mantenedores da saúde e da qualidade de vida.

Colocar a noção de "empowerment" na prática em questões de tabagismo não se efetiva, apenas, pela difusão da informação, mas pode ser conquistada por famílias e comunidades ao serem capacitadas para entender as suas próprias necessidades. Nesse sentido, a competência e sensibilidade do professor são indispensáveis.

Além disso, é necessário em primeira mão conhecer com profundidade os problemas de cada localidade, contextualizando e tomando como referência seu alunado para cuidar das conquistas e continuar progredindo.

Neste momento, torna-se de reconhecida importância a aproximação entre os pares, auxiliando em sondagens diagnósticas da comunidade a ser trabalhada. Então, é aconselhável não perder tempo fazendo reflexões pautadas no "achismo" e sim sondar o que se desconhece.

O professor que se dispõe a acolher uma prática reflexiva, não somente individual, mas coletiva, associada ao contexto social e temporal de sua ação e apoiada no saber construído, estará mais bem preparado para desempenhar seu papel. Acompanhado de mais segurança, estará retomando o reconhecimento do seu lugar na produção do conhecimento não só sobre o estilo de vida dos seus alunos como também da sua prática.

Para que esse profissional encontre espaço para adotar essa prática, e aqui é importante salientar que estamos tratando do conceito de Professor Reflexivo, é necessária a sensibilização do poder público, oferecendo-lhe melhores condições de trabalho e remuneração, de tal forma que ele tenha tempo para participar de grupos de reflexão. A conquista de momentos para reflexão de sua prática e a realização de trocas de experiências exitosas poderá não só servir de apoio técnico como, talvez, de "terapia" para o professor lidar com situações estressantes e deixar de se sentir excluído dos contextos pretensos a conquistar melhoria na qualidade da educação.

A reflexão sobre a ação gera nova reflexão, e esse constante movimento faz surgir uma prática reflexiva que poderá contribuir para a formação de uma nova 
categoria de profissionais nessas escolas; isto é, a presença do Professor Pesquisador preocupado até com sua formação pessoal de forma contínua.

Com o forte comprometimento, as conquistas educativas vão tomando corpo e transformando o ambiente da escola não em palco apenas dos professores, ou apenas dos alunos, mas sim de pessoas comprometidas com o propósito de viver bem. Também porque a escola não é minha, não é sua, mas também é minha e também é sua. Ao que parece, esse ponto de vista permite sim que se estabeleça um pertencer amoroso e cuidadoso, deixando de lado relações impessoais pautadas na idéia de uma escola nossa que esconde a falta de compromisso por estar a mercê de todos e na qual eu não sou o único responsável pela falta de ação. A adoção dessa impessoalidade pode ter uma expressão preocupante, freqüentemente manifesta através de indisciplina, desmotivação, desinteresse, vandalismo e violência, tão aclamada nos dias de hoje entre os jovens.

Finalizamos destacando que o desejo de alcançar na escola um "Ambiente Livre do Tabaco", orgulhosamente reconhecido e divulgado, estendendo sua contribuição à comunidade do entorno, é que alimentou o passo a passo deste trabalho.

O fortalecimento da Educação, comunicação e conscientização do público freqüente nas escolas promoverá e implantará medidas destacadas no Artigo 12 da Convenção Quadro para o Controle do Tabagismo; isto é, "promover amplo acesso a programas eficazes e integrais de educação e conscientização do público sobre os riscos que acarretam à saúde, o consumo e a exposição do tabaco, incluídas suas propriedades aditivas".

Em concordância ao objetivo da referida Convenção e seus protocolos, estaríamos buscando, assim, proteger as gerações presentes e futuras das devastadoras conseqüências sanitárias, sociais, ambientais e econômicas geradas pelo consumo e pela exposição à fumaça do tabaco. 


\section{Conclusões}

"A simplicidade é o último degrau da sabedoria"

Gibran 
Com muita frequiência, depoimentos longos e, não raras vezes permeados por momentos de desabafo caracterizaram a fala dos professores entrevistados.

Os discursos colhidos evidenciaram que o controle do tabagismo, já reconhecido como importante campo de ação entre as propostas de promoção da saúde na academia, também ganha destaque entre os professores. Assim, 90\% dos profissionais desta pesquisa expressaram aceitação em inserir o tema nas escolas, mesmo sem tê-lo desenvolvido anteriormente, assumindo mais essa função dentre as outras já delegadas aos professores pela sociedade e pelo poder público.

Por ter consciência dos prejuízos causados pelo hábito de fumar, não só ao aluno como também a toda a comunidade, o grupo de professores aqui entrevistados acredita que os projetos sobre tabagismo na escola requerem atitudes inovadoras e o compromisso da direção escolar no cumprimento da lei, garantindo assim a proibição dessa prática em estabelecimentos públicos. Além disso, os discursos também apontaram que esses projetos deveriam estar apoiados em materiais próprios contando com assistência de profissionais especializados.

Sendo assim, nos parece oportuno inserir como conclusão desta tese algumas sugestões para aquecer debates que poderão surgir, já que há ainda muito a ser feito.

Orientar e buscar estabelecer laços de trabalho com os professores significa conquistar um espaço considerado positivo e enriquecedor das ações de controle do tabagismo entre os jovens. Além disso, por estar associado às doenças cardíacas, respiratórias e câncer, tanto quanto às doenças decorrentes de aspectos emocionais impostos pela atual estrutura social, programas dirigidos com o intuito de reduzir o tabagismo devem ser integrados, contextualizados. O professor deve reconhecer que a educação é um processo, um todo, no qual não cabem ações fragmentadas, pois estas só permitem resolver problemas pontuais, ou até construir uma visão ilusória de resultado.

Quanto à presença do aluno fumante no espaço institucional, mesmo mostrando consciência dos prejuízos causados pelo tabagismo, houve uma diversidade de idéias entre os professores entrevistados, sendo que alguns chegaram até a relegar ao problema 
o segundo plano frente ao uso de drogas mais pesadas, ou ainda sugerir que se trata de um hábito aceito pelos próprios pais e, portanto, não poderia ser coibido nas escolas.

Embora algumas iniciativas de abordagens sobre o tabagismo tenham sido citadas durante os depoimentos, por se sentirem despreparados para uma ação mais sistemática, alguns professores adotaram, na maioria das vezes, o aconselhamento como uma iniciativa do seu compromisso com o aluno. Circunscrita apenas aos aspectos de prejuízos à saúde, geralmente abordados por disciplinas como Ciências ou Biologia, essa abordagem não recebe reconhecimento. Segundo os professores, a complexidade e o envolvimento com as condições e a qualidade do ambiente dentro e fora das escolas comprometem o trabalho. Portanto, para eles, a atenção ao controle do tabagismo deve ser reforçada em todos os níveis de atuação dos profissionais na escola e também com pais e comunidade, evitando assim que as propostas desenvolvidas se traduzam em atos frustrados, tornando-os impotentes frente à falta de apoio dos descompromissados.

Durante a investigação do papel do professor na escola, a incerteza na forma de abordagem do tabagismo por eles deve ser tomada como incentivo para a busca de novos caminhos que fortaleçam sua atuação na escola, permitindo também que os mesmos professores que já se deixaram seduzir pelo consumo do tabaco, e muitas vezes também necessitados de ajuda para a cessação, reconhecidamente não adotem um "faça o que eu falo e não faça o que eu faço" dentro da escola.

A idéia: "a atitude do professor deve ser exemplo para os alunos" se constituiu em forte ancoragem no grupo e, certamente, encontrará mais adesões entre os professores de outras escolas.

Não pretendemos aqui estabelecer com precisão, e a priori, as estratégias que devem ser utilizadas pelos educadores no controle do tabagismo, também porque, assim, estaríamos novamente adotando uma política de imposição tão contestada nos momentos atuais. Porém, por outro lado, tomando-se por base os depoimentos dos professores e apoiados na leitura de uma vasta bibliografia, temos condições de sugerir alguns pontos que poderão constituir a base de ações para caminhar ao encontro de novos paradigmas de sustentabilidade de uma sociedade mais consciente e, quem sabe, livre dos prejuízos não só do consumo do tabaco, como do tabagismo passivo. 
A aceitação quase unânime na adoção da escola como importante espaço do controle do tabagismo e a adesão de um índice maior de $60 \%$ na participação espontânea dos profissionais que acolheram esta pesquisa permitiram que, em consideração aos seus depoimentos, fossem destacadas algumas idéias propiciadoras de suas ações.

Questões intrínsecas ao tabagismo e ao ambiente escolar foram traduzidas e sintetizadas em algumas propostas norteadoras para um trabalho voltado à promoção de saúde que apresentamos aqui.

- Antes de abordar o assunto com os alunos, é importante envolver todos os segmentos da escola. É preciso que haja um comprometimento cuidadoso, acompanhado por atitudes de discrição até mesmo por aqueles que encontram dificuldades em se abster do cigarro.

- Definir, em acordo entre os pares, aqueles que poderão introduzir o assunto junto aos alunos.

- Reservar espaço para aprofundamento das questões sobre tabagismo para toda a equipe.

- Apoiar as ações na sondagem das principais idéias sobre tabagismo que perpassam entre os alunos.

- Levantar, num próximo momento, a quem os alunos recorrem para solucionar suas dúvidas quanto ao uso ou experimentação do cigarro.

- Voltar ações de apoio a quem é identificado como principal personagem da solução de dúvidas dos alunos.

- Identificar locais do primeiro contato para adequar ações de prevenção.

- Estabelecer contato com as famílias, não apenas para identificar seu grau de envolvimento nas ações de controle do tabagismo pela escola como também para reconhecer suas necessidades e aspirações.

- Cuidar para que o cigarro não seja visto como coisa de "adulto" e "proibido", pois assim corre-se o risco de reforçar o comportamento de rebeldia próprio do adolescente. 
- Não adotar como "produção de sentido" no controle do tabagismo o retrato de apenas um momento da sala de aula.

- Considerar a subjetividade das relações na produção do espaço de vida dos alunos.

- Oferecer condições, apoiadas em estratégias próprias às turmas, para que o aluno identifique os prejuízos do consumo do cigarro.

- Propor debates sobre os danos causados ao meio ambiente e aos trabalhadores rurais de toda a cadeia de produção, do plantio ao consumo do cigarro.

- Organizar momentos de reflexão sobre a política de atuação das indústrias fumageiras, desde o plantio até a divulgação e comercialização do cigarro.

- Cuidar para que o envolvimento de pais, professores, profissionais de saúde ou outras figuras de autoridade nas atividades de promoção e prevenção do tabagismo não gere comportamentos de rebeldia ou de repulsa aos conselhos oferecidos aos jovens.

- Aproximar alunos para trocas de experiências com jovens bem sucedidos nos esportes, na música, nas artes (teatro, televisão, entre outras) que não fazem uso do cigarro.

- Promover assembléias escolares estimulando a busca de propostas para o controle do tabagismo entre os próprios alunos.

- Permitir que os alunos expressem sua criatividade na elaboração de material de divulgação ou na adoção de meios de prevenção do tabagismo na comunidade.

- Estabelecer parcerias com instituições que promovam melhorias na qualidade do ambiente escolar, tais como: escolas de esportes, grupos de estudo, clube de ciências, clube do xadrez, oficina de arte-terapia, além de outros. 
- Cuidar para que os alunos sejam envolvidos em atividades que promovam autoconhecimento, permitindo assim: identificar suas aptidões, promover uma formação integral, formar valores humanos positivos e reconhecer atitudes de afastamento do consumo de cigarros pelos jovens.

- Aproveitar datas como "Dia Mundial sem Tabaco" e "Dia Nacional de Combate ao Fumo" para aquecer as discussões e acompanhar a participação da população nas ações de controle do tabagismo.

- Propiciar momentos de pesquisa junto a profissionais de saúde local e internet, para localizar materiais de divulgação e pontos de apoio ao fumante para cessação.

- Dirigir atenção à permanência das ações que ofereceram um ganho no controle do tabagismo entre os escolares.

- Reavaliar todo o processo adotado para o controle do tabagismo na escola e sempre reorientá-lo, caso ocorram recaídas.

- Organizar com a equipe a lista de ações exitosas para agregá-las ao projeto político pedagógico da escola.

- Cuidar para que as ações de controle do tabagismo sejam retomadas a cada início do ano letivo, garantindo a implementação de um código de prática.

Conquistar ainda espaço na escola para desenvolver uma atitude de luta para a prática reflexiva nos parece conveniente, não só sobre as questões de tabagismo, mas também sobre outros aspectos de formação do ambiente escolar. Essa prática pode trazer um saldo positivo e até mesmo permitir o surgimento de um novo profissional, o professor pesquisador. 


\section{Referências Bibliográficas}


Albanese M, Brumini R-Legislação sobre tabagismo: proposta de lei estadual. 2 ed. Secretaria de Estado da Saúde. São Paulo: IMESP; 2002.

ACTbr-Aliança de Controle do Tabagismo. Boletim ACT [periódico na internet]. 2007 nov [acesso 14 de novembro de 2007]; (31). Disponível em:

http://actbr.org.br/comunicacao/boletins-antigos/boletim-act-31.htm.

ACTbr -Aliança de Controle do Tabagismo. Boletim ACT [periódico na internet]. 2008 jan [acesso 25 de fevereiro de 2008]; (34). Disponível em:

http://actbr.org.br/comunicacao/boletins-antigos/boletim-act-34.htm.

ACTbr -Aliança de Controle do Tabagismo.Boletim ACT [periódico na internet]. 2008 mar [acesso 02 de abril de 2008]; (36). Disponível em:

http://actbr.org.br/comunicacao/boletins-antigos/boletim-act-36.htm.

AFUBRA- Associação de Fumicultores do Brasil [homepage na internet]. Rio Grande do Sul; 2008. [acesso em maio de 2001]. Disponível em:

http://www.afubra.com.br/principal.php.

Alarcão I. Escola reflexiva e nova racionalidade. Porto Alegre: Artemed; 2001.

Almeida FJ. O educador: magnanimidades e ambigüidades. Perspec. 2001; 15(2): 92-5.

American Academy of Pediatrics. Evironment tobacco smoke: a hazard to children.

Pediatr. 1997; 99: 639-41.

Anastasiou LGC, Alves L P. Processo de ensinagem na universidade: pressupostos para as estratégias de trabalho em aula. Joinville: Universille; 2004.

Baker F, Ainsworth S R, Dye J T, Crammer C, Thun M J, Hoffmann D, at al. Health risks associated with cigar smoking. JAMA 2000; 284(6):735-40.

Bakoula CB, Kafrit VT, Kavadias GD, Lazopouou DD, Theodoridou MC ,Matsaniotis NS. Objetive passive-smoking indicators and respiratory morbidity in young children. Lancet 1995; 346: 280-1.

Bartlett EE. The contribution of school health education to community health promotion: what can we reasonably expect. Am J Public Helth. 1981; 71: 1384-91.

Bruner JA. Cultura da educação.Porto Alegre: Artes Médicas; 2001.

Buss PM. Promoção da saúde e qualidade de vida. Ciênc Saúde Coletiva. 2000; 5: 163 77. 
Califano Jr JA. Smoking and health. A report of the surgeon general. Washington, DC: US Department of Health Education and Welfare; 1979.

Chalita G. Educação- A solução está no afeto. São Paulo: Gente; 2001.

Chiaro SD, Leitão S.O papel do professor na construção discursiva da argumentação em sala de aula. Psicol Reflex Crít. 2005; 18(3): 350-7.

Ciampo LAD, Almeida CAN, Ricco RG. A criança como fumante passiva compulsória. Rev Paul Pediatr.1999;17 (1):74-8.

Cinciprini PM, Hecht SS, Henningfield. Tobacco addiction : implications for treatment and cancer prevention. J. Natl. Cancer Instit. 1997; 89(24): 1852-67.

Contreras DJ. La autonomía del profesorado. Madrid: Morata; 1997.

Deser-Departamento de Estudos Socioeconômicos Rurais. Fumo: análise da safra 2002- 2003 e perspectivas para 2003 - 2004 .Bol Deser Conjunt Agríc, 2003; (134).

Delgado CJ. Complexidade e educação ambiental. In: Garcia RL,Organizador, Método, métodos, contramétodo. São Paulo: Cortez; 2003. p. 9-23.

Draibe SO. Welfare state no Brasil: característica e perspectivas. In: Anais do 12 Encontro Anual da ANPOCS; 1988. Águas de São Pedro, Br.

Doll R, Hill AB. Smoking and carcinoma of the lung: preliminary report. Br Med J. 1950; 2:739-48.

Doll R, Peto R, Boreham J, Sutherland I. Mortality from cancer in relation to smoking: 50 years observations on British doctors. Br J Cancer. 2005; 92: 426-9.

Dube M , Green CR. Methods of collection of smoke for analytical purposes. Recent Adv Tob Sci.1982; 8:42-102.

Elmôr MRD. Tabagismo sob a ótica da promoção da saúde: meu filho como fumante passivo. [dissertação de mestrado]. São Paulo: Faculdade de Saúde Pública- USP; 2002.

Elmôr MRD, Stewien GTM, Pererira IMT B.A Ótica da promoção de saúde sobre tabagismo: meu filho como fumante passivo. Rsbc -Rev Soc Bras Câncer. 2005; 4:40-2.

Ferraço CE. Ensaio de uma metodologia efêmera: ou sobre as várias maneiras de se sentir e inventar o cotidiano escolar. In: Oliveira IB, AlvesN. Pesquisa no/do cotidiano das escolas: sobre redes de saberes. Rio de Janeiro: DP\&A; 2002. 
Flick U. Social representations of health and illness [editorial]. Pap Soc Represent. 1995; $4(1): 1$.

Freire P. Pedagogia da autonomia: saberes necessários à prática educativa. 27 ed. São Paulo: Paz e Terra; 1996.

Freire P. Pedagogia do oprimido. 43ed. Rio de Janeiro: Paz e Terra; 2005.

Freudenberger H. Staff burnout. J Soc Issues.1974; 30: 159-65.

Gomes AMA, Albuquerque CM, Catrib AMF, Silva RM, Nations MK, Albuquerque M F. Os saberes e o fazer pedagógico: uma integração entre teoria e prática. Educar, Curitiba, 2006; (28): 231-46.

Gonzalez RFL. Comunicacion, personaidad y desarrollo. La Habana, Cuba. Editorial Pueblo y Educación, Playa; 1995.

Gordon J, Turner KM. School differences in pupil smoking: a consequence of a trade-off between health and education agendas? Health Educ. Research. 2003; 18: 580-91.

Guareschi P, Jovchelovitch S. Textos em representações sociais. 2ed. Petrópolis (RJ): Vozes; 1995.

Hallal ALL. Fatores associados ao tabagismo em escolares da região sul do Brasil.[tese de doutorado] São Paulo: Faculdade de Saúde Pública- USP; 2008.

Hillman BC, Wye JEV. Passive smoking. In Hillman BC. Pediatric respiratory disease, Philadelphia: WB Saunders; 1993.

INCA-Instituto Nacional do Câncer. Coordenação Nacional de Controle do Tabagismo e Prevenção Primária de Câncer. Práticas para implantação de um programa de controle do tabagismo e outros fatores de risco. Rio de Janeiro; 1998.

INCA-Instituto Nacional do Câncer. Coordenação de Prevenção e VigilânciaCONPREV Programa Nacional de Controle do Tabagismo e outros Fatores de Risco Brasil. Rio de Janeiro; 2001.

INCA- Instituto Nacional de Câncer [homepage na internet]. Tabagismo 2001 [acesso em março 2001] Disponível em:

http: <//www ibase.org.br/ incancer/prevenção/tabagismo/porqfuman.html.

INCA- Instituto Nacional de Câncer-Ação Global para o Controle do Tabaco- ${ }^{\circ}$ Tratado Internacional de Saúde Pública. Rio de Janeiro. 2004a. 
INCA- Instituto Nacional do Câncer. A Ratificação da Convenção-Quadro para o Controle do Tabaco pelo Brasil:mitos e verdades.Rio de Janeiro; 2004b.

INCA-Instituto Nacional de Câncer [ homepage na internet] Vigiescola- Vigilância do Tabagismo em Escolares [acesso em junho 2008]. Disponível em: http://www.inca.gov.br/vigescola/.

Janerich A. Lung cancer and exposure to tobacco smoke in the household. N Engl. J Med 1990; 323:623-6.

Lago LWC. Perfil do usuário do programa de tratamento do tabagismo do Centro de Referência de Álcool, Tabaco e outras Drogas - CRATOD- Secretaria do Estado da Saúde. São Paulo; 2006 [acesso em maio 2008]. Disponível em:

http://www.cratod.saude.sp.gov.br/apresentacoes/perfil\%20tabaco.pdf.

Lapate V. Hora zero: A independência das drogas: antes que os problemas cheguem. São Paulo: Scortecci; 2001.

Lefèvre F, Lefèvre AMC,Teixeira JJV. O discurso do sujeito coletivo: uma nova abordagem metodológica em pesquisa qualitativa. Caxias do Sul: EDUC; 2000.

Lefèvre F, Lefèvre AMC. Discurso do sujeito coletivo: um novo enfoque em pesquisa qualitativa (desdobramento). Caxias do Sul: EDUC; 2003.

Lefèvre F, Lefèvre AMC. Promoção de saúde a negação da negação. Rio de Janeiro: Vieira \& Lent; 2004.

Lei de Diretrizes e Bases da Educação Nacional. LEI N 9.394, De 20 de Dezembro de 1996. Presidência da República - Casa Civil. Subchefia para Assuntos Jurídicos [acesso em junho 2008]. Disponível em: http://www.planalto.gov.br/ccivil_03/Leis/L9394.htm

Maingueneau D. Termos-chave da análise do discurso. Belo Horizonte: UFMG; 2000.

Malcon MC, Menezes AMB, Chattkin M. Prevalência e fatores de risco para tabagismo em adolescentes. Rev Saúde Pública. 2003a; 37(1): 1-7.

Malcon MC, Menezes AMB, Maia MFS, Chatkin M. Prevalência e fatores de risco para tabagismo em adolescentes na América do Sul: uma revisão sistemática da literatura. Rev Panam Salud Publica. 2003b; 13(4): 222-8.

Marcopito L F, Coutinho A P, Valencich D M O, Moraes M A Brumini R, Ribeiro S A. Exposição ao tabagismo e atitudes: comparação entre inquéritos realizados na população adulta do município de São Paulo em 1987 e 2002. Universidade Federal de São Paulo, 
Secretaria do Estado de Saúde - São Paulo (SP) - Brasil. Arq. bras. cardiol; nov. 2007, 89(5): 333-40.

Marx K. O Capital. São Paulo: Abril Cultural, 1983. v1, Tomo 1.

Maximiano A C A. Introdução à Administração. 6a edição, Editora Atlas, 2004.

Menezes U B. A história, cativa da memória? Para um mapeamento da memória no campo das Ciências Sociais. In Rev Inst Estud Bras, 1992; 34: 9-23.

Minayo MC de S. O desafio do conhecimento: pesquisa qualitativa em saúde. 7 ed. São Paulo: Hucitec /Rio de Janeiro: Abrasco; 2000a.

Minayo MCS . Qualidade de vida e saúde: um debate necessário. Ciênc Saúde Coletiva 2000b; 5: 7-18.

Ministério da Saúde. Promoção da Saúde: Carta de Otawa, Declaração de Adelaide, Sundsvall e Santa Fé de Bogotá, Brasília; 1996.

Ministério da Saúde. Projeto Promoção da Saúde. Declaração de Alma-Ata, Carta de Ottawa, Declaração de Adelaide, Declaração de Sundswall, Declaração de Santa-fé de Bogotá, Declaração de Jacarta, Rede de Mega países e Declaração do México. Brasília: Ministério da Saúde; 2001.

Ministério da Saúde. Instituto Nacional de Câncer. Organização Pan-Americana da Saúde.Tabaco e pobreza, um círculo vicioso - a convenção-quadro de controle do tabaco:uma resposta. Brasília; 2004.

Ministério da Saúde/INCA. Secretaria de Vigilância em Saúde. Secretaria de Atenção à Saúde. Instituto Nacional do Câncer. Coordenação de Prevenção e Vigilância. Inquérito domiciliar sobre comportamento de risco e morbidade referida de doenças e agravos não transmissíveis : Brasil, 15 capitais e Distrito Federal, 2002-2003. Rio de Janeiro: INCA; 2004.

Ministério da Saúde. Portaria No 1.105/GM, de cinco de julho de 2005a. Disponível em: http://dtr2001.saude.gov.br/sas/PORTARIAS/Port2005/GM/GM-1105.htm.

Ministério da Saúde. Portaria No 2.084; de outubro de 2005b. Disponível em: http://dtr2001.saude.gov.br/sas/PORTARIAS/Port2005/GM/GM-2084.htm.

Ministério da Saúde. Portaria No 2.439/GM, de oito de dezembro de 2005c. Disponível em: http://dtr2001.saude.gov.br/sas/PORTARIAS/Port2005/GM/GM-2439.htm.

Ministério da Saúde. Portaria No 2608/GM, de 28 de dezembro de 2005d. Disponível em: http://dtr2001.saude.gov.br/sas/PORTARIAS/Port2005/GM/GM-2608.htm. 
Ministério da Saúde. Portaria No 399/GM de fevereiro de 2006a. Disponível em: http://dtr2001.saude.gov.br/sas/PORTARIAS/Port2006/GM/GM-399.htm.

Ministério da Saúde. Portaria No 687 de março de 2006b. Disponível em: http://portal.saude.gov.br/portal/arquivos/pdf/portaria687_2006.pdf.

Moraes AM. Avaliação da implantação do programa de controle do tabagismo no Hospital Santa Cruz- São Paulo- Capital. [tese doutorado] São Paulo: Faculdade de Saúde Pública, da USP; 2006.

Moreira AS, Oliveira DC. Estudos interdisciplinares de representação social. 2 ed. Goiânia: Editora AB; 2000.

Moreira FG, Silveira DX ,Andreoli SB. Redução de danos do uso indevido de drogas no contexto da escola promotora de saúde- Ciênc Saúde Coletiva 2006; 11(3): 807-16.

Morin E. Os sete saberes necessários à educação do futuro. 4 ed. São Paulo: Cortez; 2001.

Moscovici S A. Representação social da psicanálise. Rio de Janeiro: Zahar; 1978.

Must E, Efroymson D, Tanudyaya F. Controle do tabaco e desenvolvimento. manual para organizações não governamentais. São Paulo: Rede tabaco Zero/ Guia Path. Canadá; 2004.

Nardi, J B. Paradoxo, crise e perspectivas da fumicultura em Alagoas. In: Caderno de Estudos da FUNESA, Arapiraca(AL): 2003; 2.

Oliveira MLCL. Educação em saúde na escola pública: limites e possibilidades - uma reflexão histórica sobre a formação do educador [dissertação de mestrado] Rio de Janeiro: Instituto de Estudos Avançados da Faculdade Getúlio Vargas; 1991.

O’Donnell MP. Definition of health promotion: Part III: Expanding the definition. Am J Health Promot. 1989; 3(3): 5.

OPS- Organización Panamericana de la Salud. Memória da Primera Reunión y Asamblea Constitutiva - Red Latinoamericana de Escuelas Promotoras de Salud; 1996 San José; PR.

OPS . Escuela promotoras de la salud : entornos saludables y mejor salud para lãs generaciones futuras. Washington, DC : OPAS; 1998. (Comunicación para la Salud, 13). 
OPS/OMS Organización Mundial de la Salud/Organização Mundial da Saúde. Escuelas Promotoras de salud: modelo y guia para la acción. Washington, DC: OPS; 1996.

(HSP/SILOS, 36).

OPS.Organización Mundial de la Salud. Informe sobre la salud en el mundo 2007 protección de la salud pública mundial en el siglo XXI: un porvenir más seguro.Ginebra; 2007.

Pate RR, Heath GW, Dowda M, Trost SG. Associations between physical activity and other health behaviors in a representative sample of US adolescents. Am J Public Health. 1996; 86(11): 1577-81.

Pelicioni MCF, Pelicioni AF. Educação e promoção da saúde: uma retrospectiva histórica.O mundo da saúde São Paulo: 2007; 31(3): 320-328

Perrenoud P. Formation continue et développement de compétences professionnelles. L'Educateur. 1996; (9): 28-33.

Pimenta SG, Ghedin E(organizadores). Professor reflexivo no Brasil: gênese e crítica de um conceito. São Paulo: Cortez; 2005.

Pinho MD, Berquó E, Oliveira KA, Lopes F, Lima LCA, Pereira N. Juventude, raça e vulnerabilidade. Rev Bras Estud Pop. 2002; 19 (2): 277-94.

Possato M, Parada CMG de L, Tonete VLP. Representação de gestantes tabagistas sobre o uso do cigarro: estudo realizado em hospital do interior paulista. Rev. Esc. Enferm. USP. 2007; 41 (3): 434-40.

Pougy EGP. Pelas vias de uma didática da obra de arte. Educ.Pesqui. São Paulo; 2007.33(3): 485-98.

Robertson A. Shifiting discourse on health in Canadá: from health promotion to population health. Health Promot Int. 1998; 13: 155-66.

Rocha DG. O movimento da promoção de saúde na década de 1990: um estudo do seu desenvolvimento e difusão na saúde pública brasileira. [tese de doutorado] São Paulo: Faculdade de Saúde Pública da USP; 2001.

Rocha DG, Marcelo VC, Pereira IMTB. Escola promotora da saúde: uma construção interdisciplinar e intersetorial. Rev Bras Cresc Desenv Hum. 2002; 12: 57-63.

Rocha, AA. Tabaco: degradação ambiental e poluição. Rev Jovem Méd. 2001; 6: 45-53.

Roncalli AG. O Desenvolvimento das políticas públicas de saúde no Brasil e a construção do Sistema Único de Saúde. In: Pereira. AC, organizador. Odontologia em 
saúde bucal coletiva: planejando ações e promovendo saúde. Porto Alegre: Artmed; 2003. p. 28-49.

Rosemberg J. Fumo ou saúde. São Paulo Bradepca; 1985.

Rosemberg J. Tabagismo: sério problema de saúde pública. 2ed. São Paulo: Almed; 1987.

Rosemberg J.. Secretaria da Saúde. Centro de Vigilância Epidemiológica. Nicotina: droga universal. São Paulo: 2003.

Saul AM. Avaliação emancipatória: desafio à teoria e à prática de avaliação e reformulação de currículo. 3 ed. São Paulo: Cortez; 1994.

Sayão R, Aquino J G.Em defesa da escola. São Paulo: Papirus; 2004.

Schofield MJ, Lynagh M, Mishra G. Evaluation of health promoting schools program to reduce smoking in Australian secondary schools. Health Educ Res. 2003; 18: 678-92.

Schön D. The reflective practitioner. New York: Base Book; 1993.

Seed- Secretaria estadual de educação do Paraná [homepage na internet]. Curitiba; 2008. [acesso em agosto de 2008]. Disponível em:

http://www.seed.pr.gov.br/diaadia/diadia/index.

SEE-SP- Secretaria Estadual de Educação do Estado de São Paulo. São Paulo faz escola. São Paulo; 2008. [acesso em maio de 2008a]. Disponível em:

http://www.educacao. sp.gov.br/.

SEE-SP- Secretaria Estadual de Educação do Estado de São Paulo. Bolsa Mestrado.São Paulo; 2008 [acesso em novembro de 2008b]. Disponível em:

http://bolsamestrado.edunet.sp.gov.br/Decreto.aspx.

SEE-SP/lise - Secretaria Estadual de Educação do Estado de São Paulo/Legislação informatizada Secretaria da Educação. São Paulo; 2008 [acesso em março de 2008]. Disponível em: http://lise.edunet.sp.gov.br/.

Serrão MIB. Superando a racionalidade técnica na formação: sonho de uma noite de verão. In. Pimenta SG, Ghedin E. (Organizadores) Professor reflexivo no Brasil: gênese e crítica do conceito. São Paulo: Cortez; 2005. p.151-60.

Silva ALT. A saúde bucal coletiva sob a ótica de professores da rede estadual de ensino de São Paulo. [dissertação de mestrado] São Paulo: Faculdade de Saúde Pública da USP; 2002. 
Silva JO .Educação e saúde: palavras e atos .Porto Alegre: Dacasa Editora; 2001. (Série Pesquisa em saúde,14)

Simioni AMC, Lefèvre F, Pereira IMTB . Metodologia qualitativa nas pesquisas em saúde coletiva: considerações teóricas e instrumentais. São Paulo: Faculdade de Saúde Pública da USP; 1996. (Série monográfica, 2).

SPi - Sales \& Paschoal Informática, 2007. Disponível em www.spi-net.com.br.

Stewien GTM. O adolescente e o fumo. [dissertação de mestrado]. São Paulo: Faculdade de Saúde Pública da USP; 1977.

Szklo AS, Otero UB- Perfil dos fumantes que não buscam tratamento para deixar de fumar, município do Rio de Janeiro. Rev Saúde Pública. 2008; 42(1): 139-42.

UFRRJ/IA.Universidade Federal Rural do Rio de Janeiro. Instituto de Agronomia. Envenenamento por agrotóxico. [acesso 28 mar 2007 ] Disponível em : http://www.ufrrj.br/institutos/it/de/acidentes/vene.htm.

UNESCO. O perfil dos professores brasileiros: o que fazem, o que pensam, o que almejam. São Paulo: Moderna; 2004.

US Departament of Health and Human Services. Youth and tobacco: preventing tobacco use among young people. A report of the Surgeon General. Washington, DC: US Government Printing Office; 1994.

Valadão MM. Saúde na escola: um campo em busca de espaço na agenda intersetorial. [tese de doutorado]- São Paulo: Faculdade de Saúde Pública da USP; 2004.

Vygotsky LS. Aprendizagem e desenvolvimento intelectual na idade escolar. In: Luria A R, Vygotsky LS, Leontiev AN. Psicologia e pedagogia I: bases psicológicas da aprendizagem e do desenvolvimento. Lisboa: Estampa; 1977. p. 31-50.

Vynckt SV. Primary school health: where are we and where are we going? Realites in the life of school children in the third world. Hygie 1992/3; 11: 45-9.

Zlotmik J, Bechara MJ, Cordeiro AC. Campanhas de combate ao tabagismo. In: Gama JJ. Fumo ou saúde. São Paulo Bradepca; 1985.

Westphal MF. A Declaração de Jacarta sobre Promoção da Saúde no século XXI.

Mimeo; Julho de 1997.

Westphal MF. Promoção de saúde e qualidade de vida.In Rocha AA,Cesar CLG. Saúde Pública: bases conceituais. São Paulo; Atheneu, 2008. p149-63. 
WHO- World Health Organization. Report on the Global Tobacco Epidemic. The MPOWER package. [ homepage na internet]. Geneva; 2008. [acesso em 17 abril 2008 ]. Disponível em http://www.who.int/tobacco/mpower/mpower_report_full_2008.pdf.

WHO- World Health Organization. Comprehensive school health education: suggest guidelines for action. Geneva: Unesco/Unicef; 1991.

WHO- World Health Organization. Comprehensive school health Education. Geneva: Unesco/Unicef; 1992.

WHO- World Health Organization. Promotion health through schools. The World Health Organization's Global School Health Initiative. Geneva: WHO; 1996a .

WHO- World Health Organization. Improving school health programmes: barriers and strategies. Geneva: WHO/HPR/HEP ; 1996b .

WHO- World Health Organization. Strategies to overcome barriers and to improve school health programmes: a background paper for the WHO Expert Committee on school Health Education and Promotion. Geneva: WHO ; 1996c.

WHO- World Health Organization. The Status of school health. Geneva: WHO/HPR/HEP; 1996d.

WHO- World Health Organization. Building blocks for tobacco control: a handbook. Geneva: WHO, 2004.

WHO/UNESCO/UNICEF/WORD BANK . Focusing Resources on effective school health: a FRESH Start to Enhancing the Quality an Equity of Education. Dakar: WHO/UNICEF/UNESCO/World Bank; 2000.

WHO-World Health Organization. The Bangkok Charter for Health Promotion in a Globalized World. Geneva [acesso em Outubro 2005 ]. Disponível em: http://www.who.int/healthpromotion/conferences/6gchp/bangkokcharter/en.

WHO-World Health Organization. Carta de Bangkok para la promoción de la salud en un mundo globalizado.Ginebra [ acesso em 20 maio 2008]. Disponível em: http://www.who.int/healthpromotion/conferences/6gchp/BCHP_es.pdf.

World Bank. Curbing the epidemic: governments and the economics of tobacco control. Washington, DC; 1999.

World Bank. Tobacco \& health in the developing world: a background paper for the high level round table on tobacco control and development policy. Organized by the 
European Commission in collaboration with the World Health Organization and the World Bank. Brussels, Belgium; 2003.

\section{Bibliografia Complementar}

Gil AC. Como elaborar projetos de pesquisa. $3^{\text {a }}$ ed. São Paulo; Atlas,1996.

Leme AO. Promoção de Saúde em cena: considerações teóricas para uma prática teatral de Educação em Saúde. [ dissertação de mestrado] São Paulo: Faculdade de Saúde Pública da USP; 2005.

Must E, Efroymson D. Utilizando a mídia para o controle do tabagismo- Guia PATH Canadá. Rio de Janeiro; REDEH/Tabaco Zero; 2002.

Santos BS. Renovar a teoria crítica e reinventar a emancipação social. São Paulo: Boitempo; 2007.

Santos SH. Obrigado por não fumar- o cigarro não é sublime. 2 ed. Rio de Janeiro: Senac rio; 2007.

Secretaria Estadual de Educação de São Paulo - Legislação de ensino fundamental e médio federal. São Paulo; 2006. v 33.

Secretaria de Participação e Parceria da Prefeitura da Cidade de São Paulo- Guia Prático sobre Uso, abuso e Dependência de Substâncias Psicotrópicas para Educadores e Profissionais da Saúde. Organizadores: Ana Cecília Petta Roselli Marques e Marcelo Ribeiro. São Paulo; 2006.

Universidade de São Paulo. Faculdade de Saúde Pública /Guia de apresentação de teses. Angela Maria Belloni Cuenca, Maria Teresinha Dias de Andrade, Daisy Pires Noronha, Maria Lúcia Evangelina de Faria Ferraz. 2 ed. São Paulo: 2006. 
ANEXOS 


\section{Anexo 1 - Termo de Consentimento livre e esclarecido.}

Título da Pesquisa: Tabagismo sob a ótica da Promoção da Saúde: Reflexão do professor sobre sua prática.

Fui informada que a pesquisa que vou participar, faz parte da Tese de Doutorado, da aluna Maisa Rose Domenico Elmôr, do Curso de Pós-graduação da Faculdade de Saúde Pública da Universidade de São Paulo. Para tanto, estou disponibilizando tempo para responder perguntas a respeito do tabagismo na escola e autorizo sua gravação.

Estou ciente de que meus relatos ajudarão a compreender melhor o pensamento dos professores frente a estas questões e poderão fornecer subsídios para reflexões e ações voltadas à Promoção de Saúde.

Asseguro que minha participação é livre e voluntária, sem qualquer risco, podendo ser interrompida caso sinta algum desconforto.

Estou em acordo com o compromisso de manter sigilo sobre meu nome e a garantia da utilização deste material em pesquisa científica pelo pesquisador.

$$
\text { São Paulo, de de } 2006
$$

Orientador: Dr ${ }^{\mathrm{a}}$ Isabel M. B.Pereira Av. Dr Arnaldo 715 Dep.Prática de Saúde-FSP-USP Fone: 30667743
Pesquisador: Maisa R. D. Elmôr

RG 6720 111-8

Av. Dr. Arnaldo 715

Dep.Prática de Saúde-FSP-USP 


\section{Anexo 2- Termo de Compromisso Ético.}

Declaro para os devidos fins que, as informações colhidas durante a entrevista serão usadas sem que o respondente e o estabelecimento de Ensino, ao qual o professor pertença, sejam identificados.

Todas as declarações serão usadas somente para fins de pesquisa e sua divulgação e transcrição estarão dentro do contexto da investigação.

A metodologia estará fundamentada em conceitos da teoria de Representação Social inaugurada por Moscovici (1961), sendo a análise dos discursos produzidos, realizadas segundo a técnica qualiquantitativa de representação social proposta por Lefèvre e colaboradores (2000).

São Paulo, de de 2006

Maisa Rose Domenico Elmôr.

RG 6720111

Av. Dr. Arnaldo 715

Dep.Prática de Saúde-FSP-USP

Fone: 30667743 


\section{Anexo 3-Questionário a ser preenchido pelo professor}

Nome do professor

Idade Escolaridade

Estado conjugal atual Renda familiar

$\mathrm{N}^{\mathrm{o}}$ de filhos Idade dos filhos

Local de trabalho
( ) público
( ) particular
( ) ambos

Cargo Tempo no cargo

Disciplina que leciona Nível

Você é fumante?

( ) $\operatorname{sim}$

( ) não 


\section{Anexo 4- Entrevista}

1. O que é fumar para você? Fale um pouco sobre isto para mim.

2. Você acredita que o cigarro afeta outras pessoas? O que você acha disso?

3. E o aluno fumante. Como é isto para você?

4. Você já participou de alguma atividade ligada ao tabagismo na escola? Fale um pouco sobre isso.

5. Como poderia ser abordado a questão do tabagismo pelas escolas ?

6. E sobre programas relacionados ao tabagismo na escola,o que você acha disto?

7. Você quer falar mais alguma coisa? 


\section{Anexo 5}

Exemplo de Material obtido a partir do Qualiquantisoft 


\section{Anexo 6}

Gráficos e tabelas obtidos diretamente do programa de informática Qualiquantisoft utilizado para análise. 
